\title{
HYDROLOGY OF THE MELTON VALLEY RADIOACTIVE-WASTE BURIAL GROUNDS AT OAK RIDGE NATIONAL LABORATORY, TENNESSEE
}

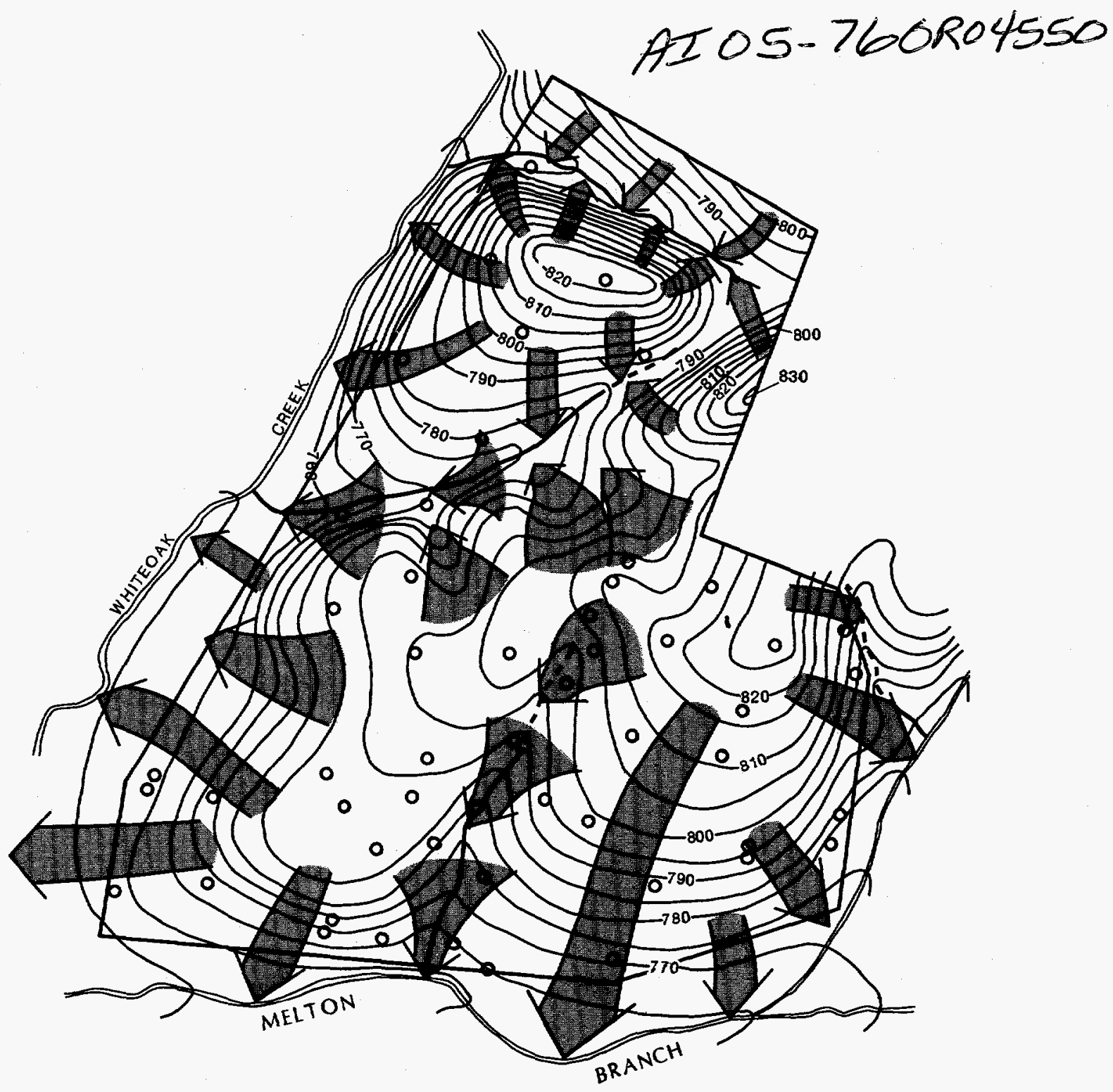

\section{U.S. GEOLOGICAL SURVEY}

Open-File Report 87-686

Prepared in cooperation with the U.S. DEPARTMENT OF ENERGY

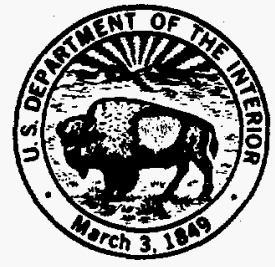


Cover illustration shows water-table contours at burial ground 5 for typical late, mid-season condition, July 14, 1983 , and general direction of ground-water. 


\section{HYDROLOGY OF THE MELTON VALLEY RADIOACTIVE-WASTE BURIAL GROUNDS AT OAK RIDGE NATIONAL LABORATORY, TENNESSEE}

\section{By D. A. Webster and M. W. Bradley}

U.S. GEOLOGICAL SURVEY

Open-File Report 87-686

Prepared in cooperation with the U.S. DEPARTMENT OF ENERGY

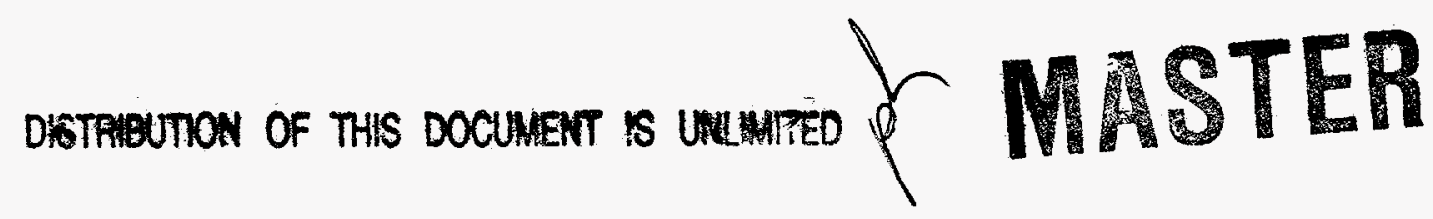




\section{DEPARTMENT OF THE INTERIOR}

\section{DONALD PAUL HODEL, Secretary}

U.S. GEOLOGICAL SURVEY

Dallas L. Peck, Director

District Chief

U.S. Geological Survey A-413 Federal Building

U.S. Courthouse

Nashville, Tennessee 37203
U.S. Geological Survey

Books and Open-File Reports Section

Federal Center, Bldg. 810

Box 25425

Denver, Colorado 80225 


\section{DISCLAMMER}

Portions of this doccoment may be illegible in electronic image products. Images are produced from the best available original document. 


\section{DISCLAIMER}

This report was prepared as an account of work sponsored by an agency of the United States Government. Neither the United States Government nor any agency thereof, nor any of their employees, makes any warranty, express or implied, or assumes any legal liability or responsibility for the accuracy, completeness, or usefulness of any information, apparatus, product, or process disclosed, or represents that its use would not infringe privately owned rights. Reference herein to any specific commercial product, process, or service by trade name, trademark, manufacturer, or otherwise does not necessarily constitute or imply its endorsement, recommendation, or favoring by the United States Government or any agency thereof. The views and opinions of authors expressed herein do not necessarily state or reflect those of the United States Government or any agency thereof. 


\title{
CONTENTS
}

\author{
Abstract 1 \\ Introduction $\mathbf{2}$ \\ Purpose and scope 4 \\ Other studies 4 \\ Acknowledgments 5 \\ The Oak Ridge National Laboratory grid 6 \\ Physiography 6 \\ Topography and drainage 6 \\ Climate 7 \\ Soils and vegetation 9 \\ Summary of site characteristics 9 \\ Geologic setting 11 \\ Stratigraphy 11 \\ Structure 16 \\ Hydrologic units 18 \\ Regolith 18 \\ Bedrock 19 \\ Ground-water hydrology 20
}

Location and construction of wells 20

Hydrology of the regolith $\mathbf{2 0}$

Method of investigation $\mathbf{2 0}$

Conceptual model of flow: the regolith $\mathbf{2 6}$

Burial ground $4 \quad 30$

Burial ground $5 \quad 37$

Burial ground $6 \quad 47$

Hydrology of the bedrock 54

Background and method of investigation $\quad 54$

Results 54

Piezometers 54

Packers 62

Aquifer tests 69

Geophysical logging $\mathbf{7 2}$

Radiochemical analyses of ground water $\mathbf{7 4}$

Conceptual model of flow: the bedrock 77

Burial ground $5 \quad \mathbf{7 7}$

Melton Valley 86

Ground-water quality 90

Surface-water hydrology 97

Drainage characteristics 97

Radionuclide discharge 101

Monitoring 102

Summary and conclusions 104

Selected references $\quad 107$

Appendix: Data of selected wells described in text and illustrations 


\section{ILLUSTRATIONS}

1. Map showing topographic features of the Oak Ridge National

Laboratory area and location of the waste-disposal areas $\mathbf{3}$

2. Graphs showing variability in annual, monthly, and mean monthly precipitation at Oak Ridge National Laboratory, 1954-1983 8

3. Geologic map of the Oak Ridge National Laboratory area and section along line A-A' 12

4. Gamma and neutron logs of well OW-6, and lithologic summary of corresponding interval at Joy No. 2 well 14

5. Geologic map of the Conasauga Group in the Melton Valley waste-disposal area, based on projection of contacts interpreted from geophysical logs 15

6-9. Maps showing locations of:

6. Wells in and near burial ground $4 \quad 21$

7. Wells in burial ground $5 \mathbf{2 2}$

8. Wells in burial ground 623

9. Wells in the vicinity of intermediate-level liquid waste disposal pits $2,3,4$, and trench $5 \quad 24$

10. Construction diagrams of typical wells finished in the regolith and bedrock $\mathbf{2 5}$

11. Map showing depth to water table at burial ground 4, June 1, $1978 \quad 32$

12. Hydrographs of five wells illustrating ground-water conditions at burial ground 433

13. Map showing water-table contours at burial ground 4 for typical mid-season condition, June 1, 1978, and general direction of ground-water flow $\mathbf{3 6}$

14. Map showing depth to water table at burial ground 5 on July 14, 1983, and location of trenches, auger holes, and below grade waste-storage structures 39

15. Hydrographs for well 436 and riser pipes in trenches 60 and $64 \quad 41$

16. Hydrographs for four wells illustrating aquifer characteristics at burial ground 5

17. Map showing water-table contours at burial ground 5 for typical late, mid-season condition, July 14, 1983, and general direction of ground-water flow $\mathbf{4 5}$

18. Map showing depth to water table at burial ground 6, May 31, $1978 \quad 48$

19. Graph showing logarithmic distribution of apparent hydraulic conductivities by formation $\mathbf{5 1}$

20. Map showing water-table contours at burial ground 6 for typical mid-season condition, May 31, 1978, and general direction of ground-water flow $\mathbf{5 2}$

21-25. Hydrographs showing head relations with depth at piezometer clusters, burial ground 5:

21. North cluster 56

22. South cluster 57

23. East cluster 59

24. West cluster 60

25. Central cluster 61 
26-30. Hydrographs showing vertical gradients at wells in burial ground 5:

26. Well 174 with packer set at 60 - to 64 -foot depth $\mathbf{6 4}$

27. Well 175 with packer set at $43-$ to 45 -foot depth 65

28. Well 176 with packer set at 52- to 54-foot depth 66

29. Well 177 with packer set at 61 - to 64-foot depth 67

30. Well 178 with packer set at 42 - to 44 -foot depth $\mathbf{6 8}$

31. Diagrams illustrating conceptual pathways of ground-water flow in the regolith and bedrock where the inferred water-table gradient is (a) normal to strike, and (b) parallel to strike $\mathbf{8 1}$

32. Diagrammatic sections of burial ground 5 showing head distribution and idealized flow paths in the vertical direction $\mathbf{8 2}$

33. Diagrammatic sections across burial grounds 4 and 6 and the intermediate-level liquid waste disposal area showing hypothesized ground-water flow patterns in the bedrock by projection of the conceptual model of burial ground $5 \mathbf{8 8}$

34. Trilinear diagram showing principal-ion composition of ground water at four depth intervals, burial ground 595

35. Map showing location of gaging stations and monitoring stations in the Whiteoak Creek drainage basin 98

36. Streamflow-duration curves for continuous-record stations in the Whiteoak Creek basin 99

\section{TABLES}

1. Summary of burial-ground characteristics, by site $\mathbf{1 0}$

2. Calculated approximate areal dip of strata in the waste-disposal area, based on contacts picked from gamma and neutron logs of wells 18

3. Aquifer-test data of wells completed in the regolith at and near burial ground $4 \quad 34$

4. Aquifer-test data of wells completed in the regolith at burial ground $5 \mathbf{4 4}$

5. Aquifer-test data of wells completed in the regolith at burial ground 649

6. Aquifer-test data of bedrock wells in the central cluster $\mathbf{7 0}$

7. Apparent hydraulic conductivities of wells in piezometer arrays $\mathbf{7 1}$

8. Results of spectral logging of wells in burial grounds 5 and $6 \quad 74$

9. Radiochemical analyses of well water, burial ground $5 \quad \mathbf{7 6}$

10. Principal-ion, minor constituent, and trace metal analyses of water samples from piezometers, burial ground 591

11. Station characteristics and flow data of the gaging stations at Whiteoak Creek and Melton Branch, through $1981 \quad 100$

12. Concentrations of selected radionuclides in small drainages of the burial grounds during extended dry periods 103 


\title{
CONVERSION FACTORS AND ABBREVIATIONS OF UNITS
}

Factors for converting inch-pound units to International System of Units (SI) are shown to four significant digits.

\section{Multiply}

inch (in.)

foot (ft)

mile (mi)

scluare mile $\left(\mathrm{mi}^{2}\right)$

acre

foot per day (ft/d)

square foot per day $\left(\mathrm{ft}^{2} / \mathrm{d}\right)$

gallon per minute ( $\mathrm{gal} / \mathrm{min}$ )

cubic foot per second $\left(\mathrm{ft}^{3} / \mathrm{s}\right)$

cubic foot per second per square mile $\left[\left(\mathrm{ft}^{3} / \mathrm{s}\right) / \mathrm{mi}^{2}\right]$

degree Fahrenheit ( F)
By

25.4

0.3048

1.609

2.590

0.4047

0.3048

0.0929

0.06308

0.02832

0.01093

To obtain

\author{
millimeter (mm) \\ meter (m) \\ kilometer $(\mathrm{km})$ \\ square kilometer $\left(\mathrm{km}^{2}\right)$ \\ hectare (ha) \\ meter per day $(\mathrm{m} / \mathrm{d})$ \\ square meter per day $\left(\mathrm{m}^{2} / \mathrm{d}\right)$ \\ liter per second $(\mathrm{L} / \mathrm{s})$ \\ cubic meter per second $\left(\mathrm{m}^{3} / \mathrm{s}\right)$ \\ cubic meter per second per \\ square kilometer $\left[\left(\mathrm{m}^{3} / \mathrm{s}\right) / \mathrm{km}^{2}\right]$ \\ degree Celsius ( C)
}

$0.5556 \times(\mathrm{F}-32)$

Sea level: In this report "sea level" refers to the National Geodetic Vertical Datum of 1929 (NGVD of 1929)--a geodetic datum derived from a general adjustment of the firstorder level nets of both the United States and Canada, formerly called "Sea Level Datum of $1929^{\prime \prime}$. 


\title{
HYDROLOGY OF THE MELTON VALLEY RADIOACTIVE-WASTE BURIAL GROUNDS AT OAK RIDGE NATIONAL LABORATORY, TENNESSEE
}

\author{
By D. A. Webster and M. W. Bradley
}

\section{ABSTRACT}

Burial grounds 4, 5, and 6 were used sequentially from 1951 to the present for the disposal of solid, low-level radioactive waste by burial in shallow trenches and auger holes. Abundant rainfall, a generally thin unsaturated zone, geologic media of inherently low permeability, and the operational practices employed have contributed to partial saturation of the buried waste, leaching of radionuclides, and transport of dissolved matter from the burial areas. Two primary methods of transport from these sites are by dissolution in circulating ground water, and the overflow of fluids in trenches and subsequent flow across land surface.

The waste-disposal areas are underlain by the Conasauga Group (Cambrian age), a complex sequence of mudstone, siltstone, and limestone interbeds grading from one lithotype to the other, both laterally and vertically. Compressional forces that caused regional thrust faulting also caused much internal deformation of the beds. Folds, bedding-plane faults, and joints are widespread. Small solution openings have developed in some areas where the structurally- related openings have provided ingress to ground water.

Both the regolith and bedrock sections of the aquifer are anisotropic, but anisotropy is more pronounced in the bedrock. The lower practical limit of ground-water circulation probably occurs at about 200 to 250 feet depth. A conceptual model of flow is described wherein the primary control on direction of ground-water flow changes from the water-table gradient in the regolith to the hydraulic head distribution within the secondary openings of the bedrock and the three-dimensional geometry of those openings. Locally, the direction of flow in the regolith also is controlled by gradients within openings in certain relatively resistant beds and structurally-related features. Hydraulic conductivities as measured by slug tests of wells range from $2.9 \times 10^{-3}$ to 6.7 feet per day in the regolith, and $1.5 \times 10^{-4}$ to $1.9 \times 10^{-1}$ feet per day in bedrock at depths of 100 to 200 feet.

Whiteoak Creek and its tributaries receive all overland flow from trench spillage, surface runoff from each site, and discharge of ground water from the regolith of each site. Potentiometric data indicate that this drainage system 
also receives ground water discharged from the bedrock of burial ground 5. By projection of the bedrock flow patterns characteristic of this site to other areas of Melton Valley, it is inferred that discharge from the bedrock underlying burial grounds 4 and 6 also is to the same drainage system. The differences in potentiometric heads and a comparatively thin saturated zone in bedrock do not favor the development of deep flow through bedrock from one river system to another.

Hydraulic potentials, hydraulic conductivities, and hydrochemical data indicate that most ground water in the aquifer flows through the regolith. A smaller amount of water flows through the bedrock, where the flow paths are longer in distance and the time of travel is considerably greater. In burial ground 5 the regolith section of the aquifer has widespread contamination, principally by iron, tritium, and strontium90. Contamination decreases substantially with increasing depth in bedrock, particularly below 100 feet.

The sites have received little monitoring because they have not been considered a hazard. As improvements in plant facilities have reduced the discharge of radionuclides to the Whiteoak Creek system, the discharge of contaminants from the burial grounds has become relatively more significant. The burial grounds are now a principal source of ${ }^{3} \mathrm{H}$ and a major contributor of ${ }^{90} \mathrm{Sr}$ in the discharge of Whiteoak Creek to the Clinch River.

\section{INTRODUCTION}

Oak Ridge National Laboratory (ORNL) is a nuclear-energy research center, located in eastern Tennessee, about 25 miles west of Knoxville and 150 miles east of Nashville. It is one of three major facilities in the Oak Ridge Reservation that are administered by the U.S. Department of Energy. ORNL, like the other two facilities, resulted from the World War II effort to produce a weapon powered by a fissionable fuel. A by-product of this effort and the many subsequent research programs at the Laboratory has been the production of large volumes of solid, liquid, and gaseous wastes contaminated by radioactive matter. Common practice at ORNL, as well as at several sister federal installations in the United States, has been to dispose of the solid-waste fraction having "low-level activity" by burial in shallow trenches. The trenches are located in dedicated sites termed "burial grounds" or "solid-waste storage areas". To date (1985), five sites at ORNL have been used sequentially, and a sixth site presently receives waste. The first three burial grounds are comparatively small sites, and are located in Bethel Valley (fig. 1) in proximity to what were, at the time of use, the principal sources of waste generation. Burial grounds 4, 5, and 6 are larger, and are sited in Melton Valley, the adjacent valley to the southeast.

Trench disposal of radioactive waste is a modification of the common practice of burying municipal waste in sanitary landfills. The practice presumes that the radioactive contaminants will be stored in the geologic media at least until such time as the natural process of radioactive decay renders those contaminants harmless to 


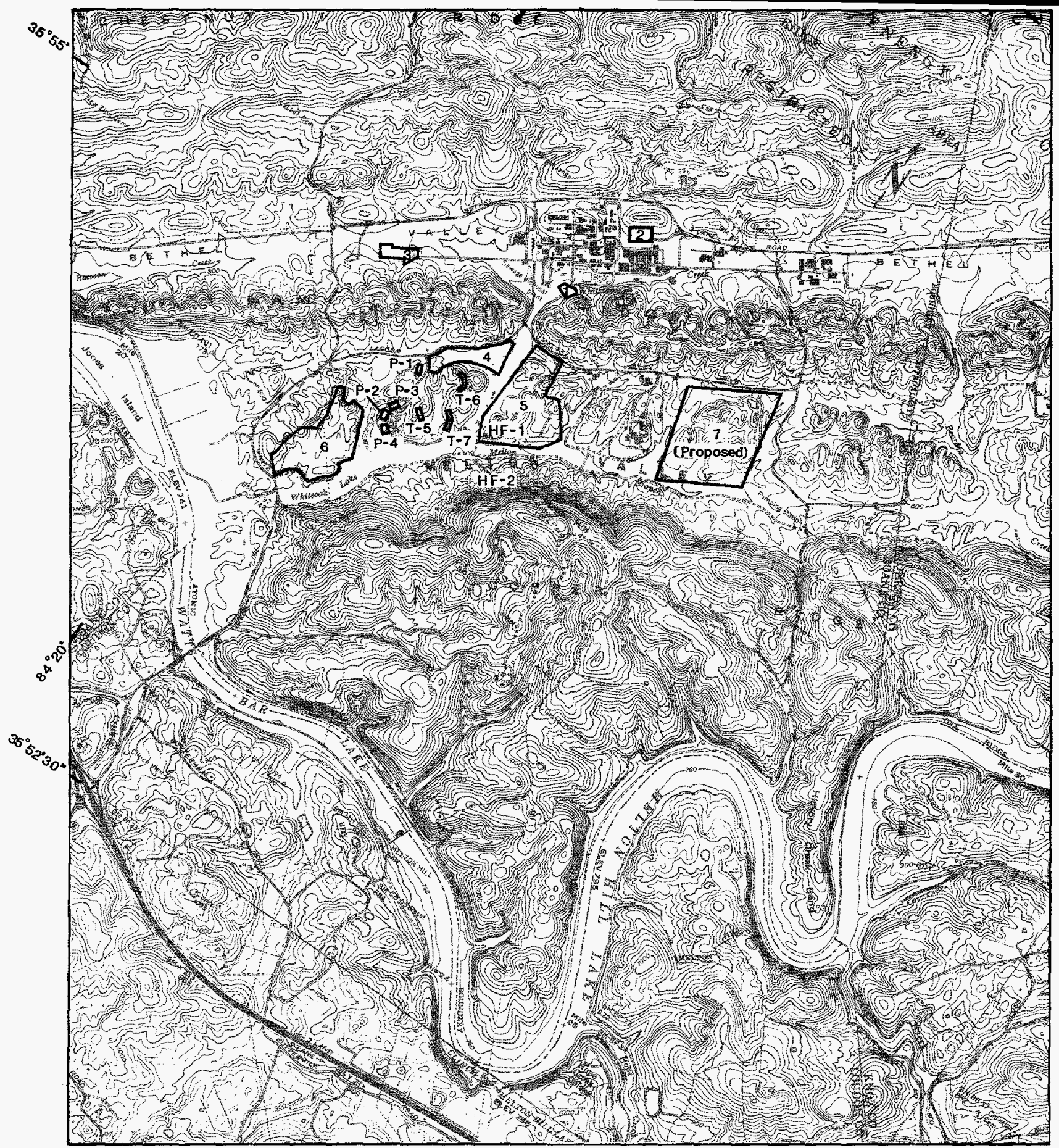

Base from USGS-TVA Bethel Valley, Lenoir City, and Lovell, $1: 24,000,1968$

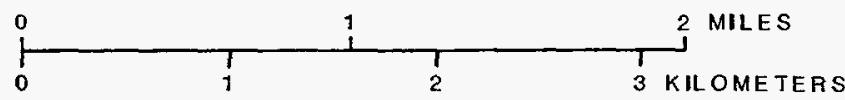

EXPLANATION

CONTOUR INTERVAL. 20 FEET

NATIONAL GEODETIC VERTICAL DATUM

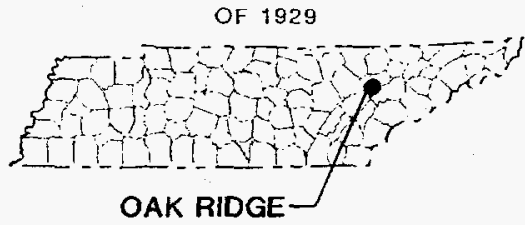

NATIONAL LABORATORY

Figure 1.--Topographic features of the Oak Ridge National Laboratory area and location of the waste-disposal areas. 
man. Although it is unlikely that the role of water in transporting interred substances was given consideration when this practice began, water now is recognized as the principal mechanism by which contaminants are mobilized and transported to the biosphere. Indeed, the containment of contaminants in the geologic media is a complex function of many hydrologic, geologic, and chemical factors, but of these, those involving water are paramount.

Streams draining the ORNL complex are known to contain radionuclides from several sources. For more than a decade, the ORNL burial grounds have been identified as one of those sources. This implies ground-water transport of contaminants from those sites and discharge into the streams. Recognizing that if the trench burial of contaminated waste is to remain a viable approach to disposal, the Department of Energy, as responsible steward of the nuclearenergy complex, has authorized studies aimed at reducing the mobility of the interred radionuclicles, developing improved technology for radioactive waste disposal, and defining the probable pathways of radionuclide migration. The participation of the U.S. Geological Survey in this effort represents one of those studies.

Study of the Melton Valley waste-disposal areas has been made in cooperation with the Department of Energy's Oak Ridge Operations Office.

\section{PURPOSE AND SCOPE}

This report discusses the hydrology of burial grounds 4,5 , and 6 in order to provide in- formation leading to (1) the design of surveillance networks for monitoring radionuclide migration from these sites, (2) the development of numerical models that simulate the groundwater flow system at each of them, and (3) the evaluation of measures proposed to reduce the transport of radionuclides in water from the burial grounds. Conceptual models of two- dimensional ground-water flow at burial grounds 4,5 , and 6 , and of three- dimensional flow at burial ground 5 , are developed. The three-dimensional concept is projected to burial grounds 4 and 6 , although potentiometric data of the bedrock in those areas is not available to support the interpretation. Consideration of the surface-water system is included, but is necessarily brief because records are of inadequate duration. The chemical quality of water from 16 wells in burial ground 5 also is discussed and related to the conceptual flow patterns at that site.

The investigation is continuing. Much work remains to be done in order to fully understand the complexly interrelated geology, hydrology, and chemistry of this system. The interpretations provided herein summarize current understanding of the hydrology of these sites and provide a basis upon which others in this and related fields can build.

\section{OTHER STUDIES}

Owing to the biological hazard associated with radioactivity and the uncertainty regarding the fate of radionuclides committed to the earth, numerous studies have been made into the field of radioactive-waste disposal at shallow depth and related areas. The investigations cover many 
disciplines, reflecting the multifaceted nature of the problem. Those studies having a close relation to this one are cited in the following statements. Additional studies are listed under "Selected References".

The first investigator to study a specific area within Melton Valley for its waste-disposal potential was Barnett (1954), who mapped and described the geology of the area between burial grounds 4 and 6. McMaster $(1962,1963)$ mapped and prepared a short description of the geology of the Oak Ridge Reservation. Haase and Vaughn (1981) identified six formations of the Conasauga Group that underlies Melton Valley, and Haase and others (1985) described those units and the underlying Rome Formation in detail.

The burial grounds have been the subject of several investigations. A study of burial ground 4, after the waste-burial operation had terminated, was made by Lomenick and Cowser (1961). Investigations to determine the suitability of areas that became burial grounds 5 and 6 were made by Cowser and others (1961), and by Lomenick and Wyrick (1965), respectively. A review of hydrologic and geologic conditions at burial grounds 1 through 6 , as of 1974 , was made by Webster (1976); the current work is an outgrowth of recommendations made therein. In anticipation of need for another burial ground after space in the site currently used becomes exhausted, a study of proposed burial ground 7 has been described by Rothschild and others (1984a).
The former practice of discharging intermediate-level radioactive liquid waste ${ }^{1}$ into open pits and trenches, located in the "ILW area" between burial grounds 4 and 6 (fig. 1), has been described in several reports. Among them are papers by deLaguna (1956), and deLaguna, Cowser, and Parker (1958). Recently, a discussion of the chemical, geologic, and hydrologic factors controlling radionuclide migration from ILW trench 7 was prepared by Olsen and others (1983).

The hydrology of the local streams was discussed by McMaster (1967), and water quality of the surface-water system described by Pickering (1970).

Water-level data for wells in burial grounds 3, 4, 5, and 6 from 1975 to 1979 were reported by Webster and others (1981b, 1981a, 1982a, and 1980 , respectively). Subsequent water-level data, precipitation data, chemical analyses of well water and stream discharge data are in the files of the U.S. Geological Survey. The data in these reports and files provide part of the foundation for the interpretations herein.

\section{ACKNOWLEDGMENTS}

Many persons at Oak Ridge National Laboratory have contributed to this endeavor. In particular, the authors cite C.S. Haase whose concurrent study of the Conasauga Group has provided an understanding of the complex geology of the waste-disposal area, and portions of whose work have been summarized to describe

\footnotetext{
${ }^{1}$ Intermediate-level radioactive waste is an ORNL term not generally recognized by the nuclear industry. It refers to liquid wastes having activity levels higher than that feasible for treatment in ORNL's waste-water treatment plant.
} 
the geologic setting given herein; personnel of the Plant and Equipment Division who frequently provided logistical support and participated in the construction of numerous shallow wells; R.E. Holmes and others of the Engineering Division, who furnished maps and updated survey data as needed for the interpretation of the water-level data; T.G. Scott, Hugh Parker, and N.M. Ferguson of the Analytical Chemistry Division, who performed radiochemical and trace-metal analyses of water samples; and many persons in the Environmental Sciences Division who supported the work with friendly help, encouragement, and innumerable thoughtful discussions concerning their field of expertise as it pertains to the wastedisposal areas. The authors also express their appreciation to Oak Ridge National Laboratory; Martin Marietta Energy Systems, Incorporated, which operates the Laboratory for the U.S. Department of Energy; and Accu-Air Surveys for permission to include materials from maps prepared by those organizations.

\section{THE OAK RIDGE NATIONAL LABORATORY GRID}

The terms north, south, east, and west as used in much of the literature of the waste-disposal areas are referred to the ORNL grid system, a relic of ORNL's World War II years. The orientation of the grid follows that of the ridges and valleys, with north, south, east, and west rotated about $34^{\circ}$ counterclockwise of the true compass directions. Directions as used in the text of this report follow standard convention rather than those of the ORNL grid. Arrows depicting both true north and ORNL north are shown on those maps made from an ORNL base.
Although geology was not a consideration in devising the grid system, it is not fortuitous that ORNL east-west corresponds to the direction of regional formation strike, and ORNL south, to the direction of regional dip.

\section{PHYSIOGRAPHY}

\section{TOPOGRAPHY AND DRAINAGE}

ORNL is located in the Tennessee section of the Valley and Ridge Province, (Fenneman, 1938), an area characterized by a series of multiple, northeast-trending valleys and ridges. The Laboratory facilities extend across a succession of alternating ridges and valleys which, starting at the Clinch River and progressing to the northwest, are Copper Ridge, Melton Valley, Haw Ridge, Bethel Valley, and Chestnut Ridge (fig. 1). The valley floors are at altitudes of about 800 feet above sea level; the ridges culminate at altitudes of about 1,000 to 1,300 feet above sea level.

Melton Valley is about $4 \frac{1}{2}$ miles long and 1 mile wide. Its northeast and southwest ends are terminated by impounded segments of the Clinch River as that river makes a broad bend around Copper Ridge. Below the steep hills of the ridge along the northwest side of the valley is a line of foothills having a maximum relief of about 100 feet. It is on these hills in the southwest half of the valley that the radioactive-waste disposal operations in burial grounds 4,5 , and 6 have been carried out.

Many valleys of this area are characterized by a high drainage density. In Melton Valley 
numerous short tributaries to the principal streams occur at intervals seldom greater than 2,000 feet. Because of drainage density and burial ground size, drainages are included within each burial ground, and one or more drainages provides a natural boundary to each site.

Surface drainage in the ORNL area trends to the southwest. Whiteoak Creek, one of several small streams in Bethel Valley, rises from springs on Chestnut Ridge, drains the Bethel Valley section of the complex, passes through a water gap in Haw Ridge to enter Melton Valley, receives the flow of Melton Branch, and discharges to Watts Bar Lake, an impounded section of the Clinch River. Twenty miles downstream from the mouth of Whiteoak Creek, the Clinch River empties into the Tennessee River, the master drainage of the region.

\section{Climate}

Eastern Tennessee characteristically has a warm, humid climate. The mean annual air temperature at ORNL for the period 1945-64 was $14.5^{\circ} \mathrm{C}$. Mean annual precipitation at stations in the environs of ORNL during the period 195483 was 52.2 inches (Air Resources Atmospheric Turbulence and Diffusion Laboratory, 1972; Gray Henderson, ORNL, written commun., 1976; Webster and others, 1982b; D.A. Webster and B.W. McMaster, U.S. Geological Survey, written commun., 1984). Minimum and maximum precipitation were 35.3 inches and 74.8 inches, respectively, or -32 percent and +43 percent of the norm. It is worthy of note that the Oak Ridge facilities have the highest mean an- nual precipitation of all the radioactive solidwaste burial grounds in the United States.

Mean monthly precipitation during the 30 year period ranged from 3.01 inches in October to 5.74 inches in March, but the variability in monthly precipitation is much greater than this narrow range implies. During the period of record, each month has been very dry at least once and also very wet at least once. Variability in both the monthly and annual precipitation is shown in figure 2.

Storm events occur with a relatively high frequency, or conversely, periods having sustained lack of precipitation occur with low frequency. Periods of 5 or more consecutive days without measurable rainfall may occur as many as 20 times per typical year; periods of 10 or more consecutive days, 3 to 6 times; and periods of more than 10 consecutive days, 2 to 4 times. The absence of rain over a 30-day interval is rare.

The ability of each site to hold radionuclides buried in shallow trenches is related to climatic factors. The relative abundance of rain throughout the year (1) sustains the water table at shallow depth; (2) contributes to the development of a high drainage density, thereby reducing the distance of contaminant travel and the period of contaminant residence below ground; (3) enhances lower soil pH's and influences the development of specific clay minerals, factors that can control or modify the transport of radioactive ions; and (4) less directly, influences the composition of the natural biological community, which also is a factor in contaminant mobility (Richardson, 1963). 

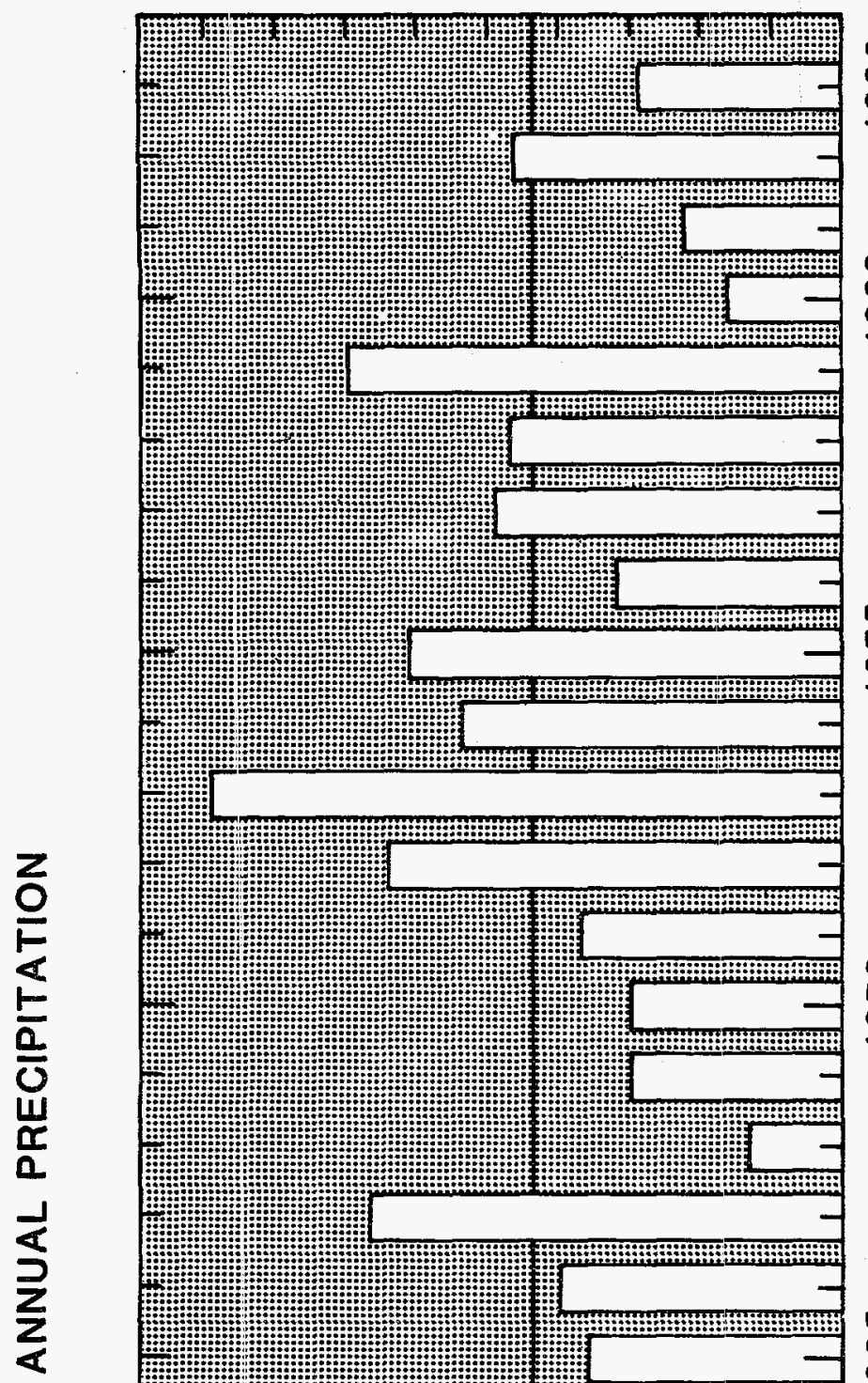

$\infty$
$\infty$
$\infty$

0
$\infty$
$\infty$
0

$z$
$\frac{Z}{F}$
$\frac{1}{k}$
$\frac{1}{0}$
$\frac{1}{\pi}$
$\frac{1}{0}$
$\frac{1}{2}$
$\frac{2}{z}$

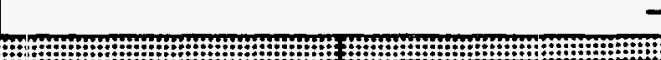

$\stackrel{n}{2}$

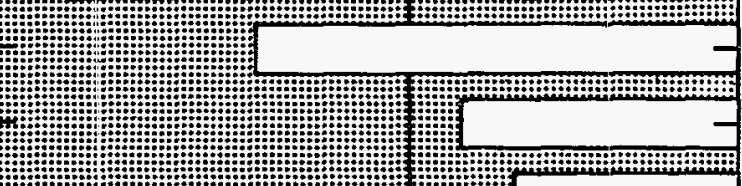

웅
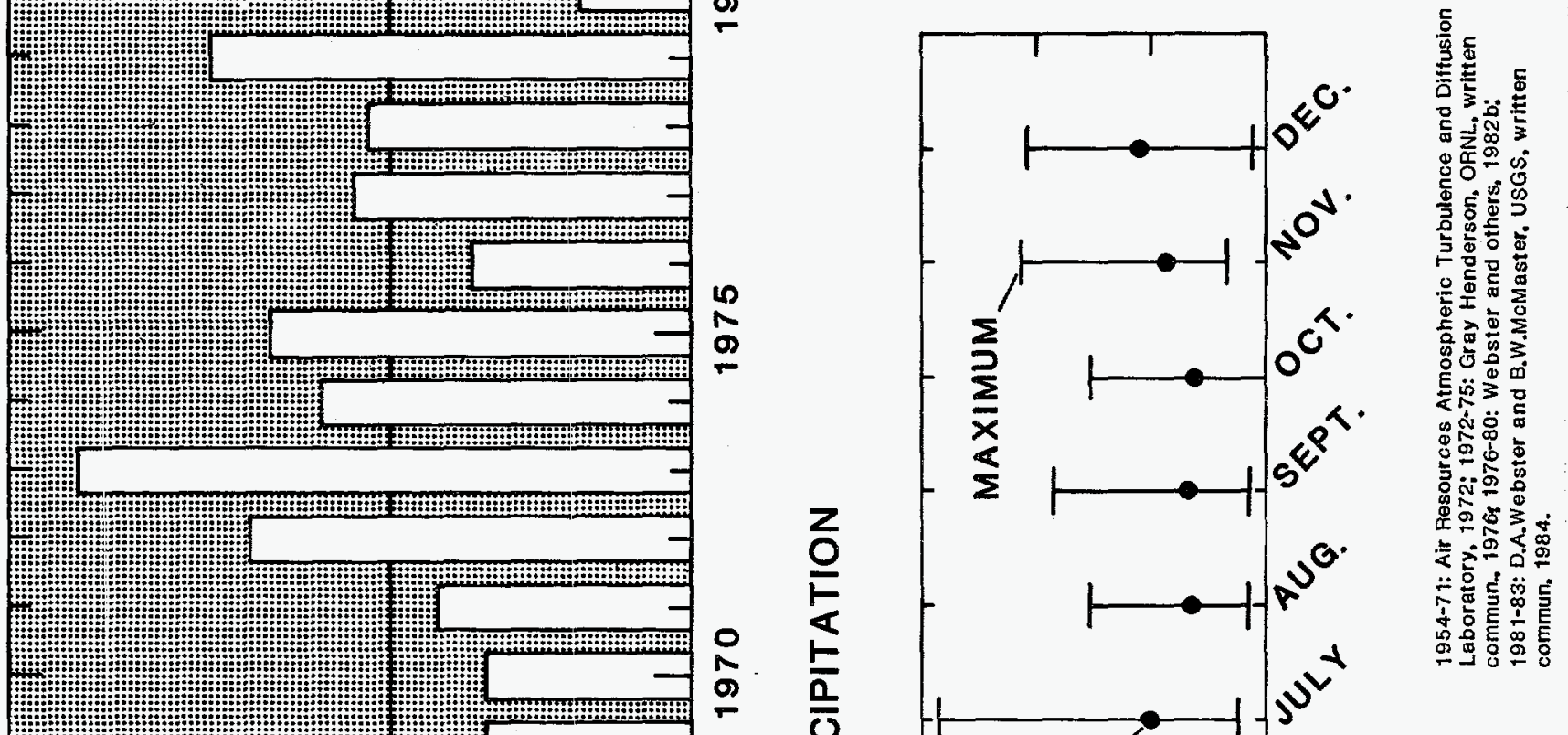

들

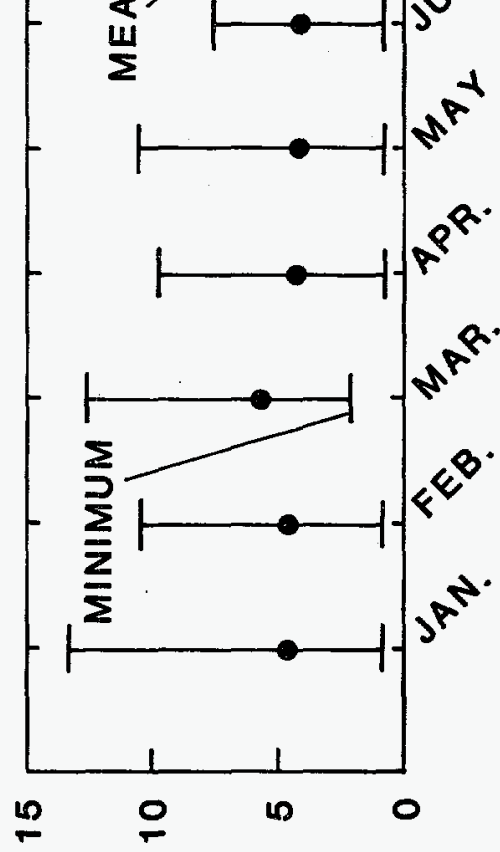

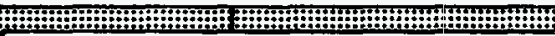

0
0
0
0

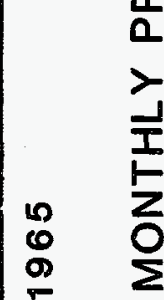
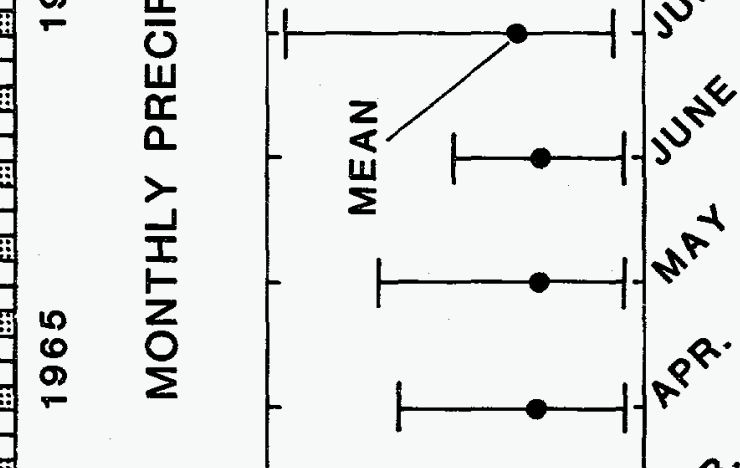

(-)

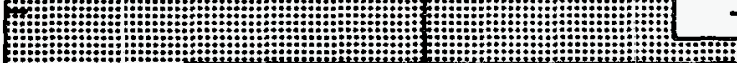

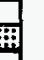

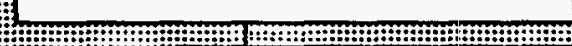

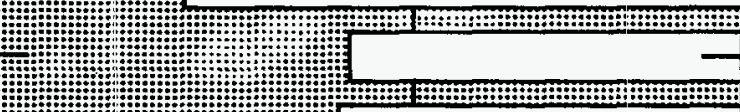

7in:

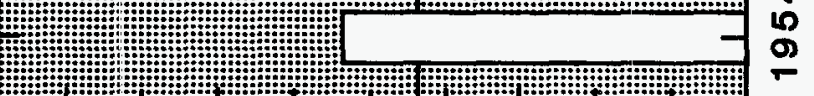

SヨHONI NI

'NOIL $\perp$ IdIO $\exists$ Gd

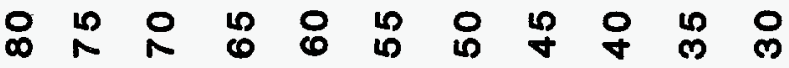




\section{SOILS AND VEGETATION}

Soils developed in the warm humid climate of this area are strongly leached and low in organic matter. Soils in the burial ground areas are silty, although considerable clay is present, and acidic in reaction with a range in $\mathrm{pH}$ from about 4.5 to 5.7 (Carroll, 1961, p. 12). The depth of true soil development generally is thin. The subsoils in which waste is buried usually consist of moderately- to highly-weathered rock.

Natural vegetation at the sites consists of mixed stands of deciduous and coniferous trees. Burial ground 4, located in a lowland, probably was a cultivated field or pasture before being incorporated in the Oak Ridge Reservation in 1942. Burial grounds 5 and 6 were heavilywooded areas before they were developed as disposal sites.

The significance of vegetation is two-fold. First, the trees have been replaced by grasses which transpire less water from the subsurface, thereby altering components of the hydrologic budget from the natural condition. Second, if the burial grounds were not maintained in grasses, trees would re-establish themselves in these areas through natural succession. Their deep roots would extend into the buried waste, contaminated subsoils, and in some places the zone of saturation, and bring radioactive contaminants to land surface in woody material and leaf litter, which upon decay could be transferred to the atmosphere as airborne dust and debris and to the drainages as particulate matter. Trees thus have potential to provide a major new pathway for contaminant transport that is not further considered herein.

\section{SUMMARY OF SITE CHARACTERISTICS}

Some of the more pertinent physical characteristics and historical data of burial grounds 4 , 5 , and 6 are summarized in table 1 . The reader is referred to publications cited under "Selected References," particularly those by Webster $(1976,1979)$ and Evaluation Research Corporation (1982), for greater detail.

Two non-standard conventions pertaining to descriptions of burial grounds 4 and 5 have been used in this report. First, one of the maps of burial ground 4 (fig. 6) includes two boundaries on the south and east perimeter of the site. The exact boundary of this burial ground is not known because maps and other records of the disposal site were destroyed in a fire. It is thought that the boundary based on ORNL drawing 58754 more closely approaches the actual perimeter of the site inasmuch as it is based on earlier record. The other indicated boundary reflects the perimeter of the disposal area based on present features. Second, the description of burial ground 5 in table 1 of this report is divided into two sections. The southern section, referred to as the "5-south" area, is where disposal operations continued after burial ground 4 was closed. The "5-north" area, a later addition to burial ground 5 , contains the facilities for the retrievable storage of transuranic (TRU) waste.

Surprisingly little detail is known of the waste that has been consigned to burial owing to the difficulty and impracticality of describing and assaying the materials that become contaminated trash. A summary statement can be made that the waste consists of a wide variety of 
Table 1.--Summary of burial-ground characteristics, by site

\begin{tabular}{|c|c|c|c|}
\hline Site & $\begin{array}{l}\text { Size, in acres } \\
\text { (hectares) }\end{array}$ & $\begin{array}{c}\text { Period of } \\
\text { use }\end{array}$ & Characteristics \\
\hline 4 & $\begin{array}{l}23 \\
(9.3)\end{array}$ & $1951-1959$ & $\begin{array}{l}\text { Developed near the bottom of a small drainage basin } \\
\text { adjacent to Whiteoak Creek and a small tributary } \\
\text { stream. Central part of site is crossed by three } \\
\text { drainages with ephemeral flow. } \\
\text { Trenches in some areas, particularly in central area } \\
\text { and low-lying areas were excavated below the water } \\
\text { table. } \\
\text { Fill and other construction debris were deposited over } \\
\text { trenches after site closure, principally on eastern end } \\
\text { where land surface has been raised by as much as } \\
10 \text { feet. } \\
\text { French drain excavated in } 1983 \text { along sections of } \\
\text { Lagoon Road (north boundary of site) to intercept } \\
\text { surface runoff from Haw Ridge and some of ground- } \\
\text { water recharge to site. }\end{array}$ \\
\hline
\end{tabular}

\section{5-south 57}

(23.1)
$1958-1973$

Deve

Developed on hillside of gentle to moderate slope; total relief about 100 feet. About 70 percent of site perimeter lies adjacent to drainages (Whiteoak Creek, Melton Branch, and two tributaries); south face bisected by tributary with nearly perennial discharge.

Trenches in low-lying areas penetrate the water table.

\begin{tabular}{|c|c|c|c|}
\hline 5-north & $\begin{array}{c}25 \\
(10.1)\end{array}$ & 1970-present & $\begin{array}{l}\text { Contains 9-acre section referred to as the "TRU area" } \\
\text { for the retrievable storage of Class B Transuranic } \\
\text { Waste (wastes having measurable radiation greater } \\
\text { than } 10 \text { loil/kg). TRU area is developed on hillside } \\
\text { of gentle to moderate slope; bordered on west by } \\
\text { Whiteoak Creek and to north and south by tributaries } \\
\text { having seasonal flow. }\end{array}$ \\
\hline 6 & $\begin{array}{l}68 \\
(27.5)\end{array}$ & 1973-present & $\begin{array}{l}\text { Developed on hillside of gentle to moderate slope. } \\
\text { Bounded on south by Whiteoak Lake and on east by } \\
\text { a drainage having seasonal flow. Site is crossed by } \\
\text { three small drainages having seasonal flow. } \\
\text { Trenches in some areas have been cut below the } \\
\text { water table; since 1975, effort has been made to } \\
\text { restrict length and depth. French drain } 826 \text { feet long, } \\
30 \text { feet deep, constructed in central part of site in } \\
1983 \text {, now intercepts local ground-water flow. }\end{array}$ \\
\hline
\end{tabular}


material; it has been packaged in an assortment of containers, or often in no container at all; it has originated at facilities nationwide; it includes a broad spectrum of radionuclides; and it contains levels of activity ranging from very low to high, even though the ORNL waste does not meet the nuclear industry's definition of "highlevel waste"; succinctly, the waste is heterogeneous and it is radioactive.

The waste materials for the most part have been loosely dumped into trenches that usually are not over 15 feet deep but are of variable length, width, and orientation. Auger holes as much as 3 feet in diameter have been used for the disposal of certain categories of waste. Trenches with alpha emitters in burial ground 4 and initially those in burial ground 5 , and the auger holes in burial grounds 4,5 , and 6 , have been capped with concrete and then covered by spoils from the excavation. Trenches with beta-gamma activity at all three sites have simply been backfilled with spoils.

From the standpoint of hydrology, the two most significant factors are (1) the existence in the subsurface of a loosely-packed, potpourri of radioactive trash differing greatly in physical properties from the native material that surrounds it; and (2) its interment in some areas below the present water table.

\section{GEOLOGIC SETTING}

\section{STRATIGRAPHY}

The ORNL area spans, in ascending order, four major geologic units: the Rome Formation of Early and Middle Cambrian age, the Conasauga Group of Middle and Late Cambrian age, the Knox Group of Late Cambrian and Early Ordovician age, and the Chickamauga Limestone of Middle and Late Ordovician age (McMaster, 1962). These units underlie Haw Ridge, Melton Valley, Chestnut Ridge and Copper Ridge, and Bethel Valley, respectively (fig. 3). All of the Melton Valley waste-disposal facilities have been developed on the Conasauga.

The Conasauga Group is a marine, shelf deposit of variable lithology. In the east central part of Tennessee, the Conasauga consists of a complex sequence of clastic-rich units alternating with carbonate-rich units, representing a transitional zone between the shallow-shelf and deep-shelf environment. Estimates of its thickness in the Oak Ridge area range from about 1,500 feet (McMaster, 1963, p. 10) to nearly 1,900 feet (Haase and others, 1985).

Six formations assigned to the Conasauga Group have been recognized in core from numerous wells in Melton Valley and in Bear Creek Valley, which lies immediately northwest of Chestnut Ridge (Haase and Vaughn, 1981, p. 8). The formations are, in ascending order, the Pumpkin Valley Shale, Rutledge Limestone, Rogersville Shale, Maryville Limestone, Nolichucky Shale, and Maynardville Limestone.

Summary descriptions of the formations, from the work of Haase and others (1985), follow. The Pumpkin Valley Shale is informally divisible into a lower member, consisting of noncalcareous siltstone with interbeds of mudstone, siltstone, and fine-grained sandstone, and an upper member, consisting of mudstones and 

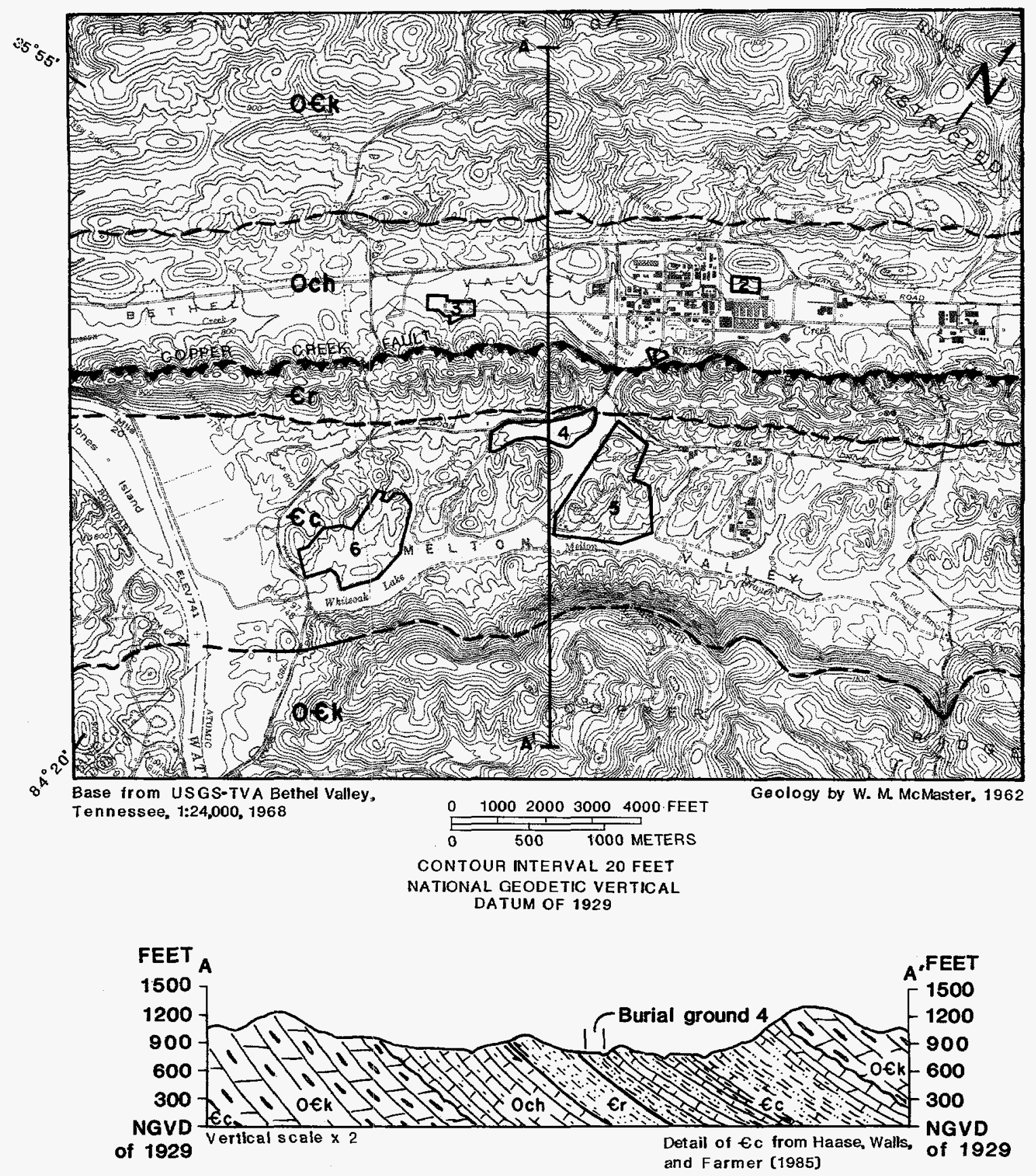

\section{EXPLANATION}

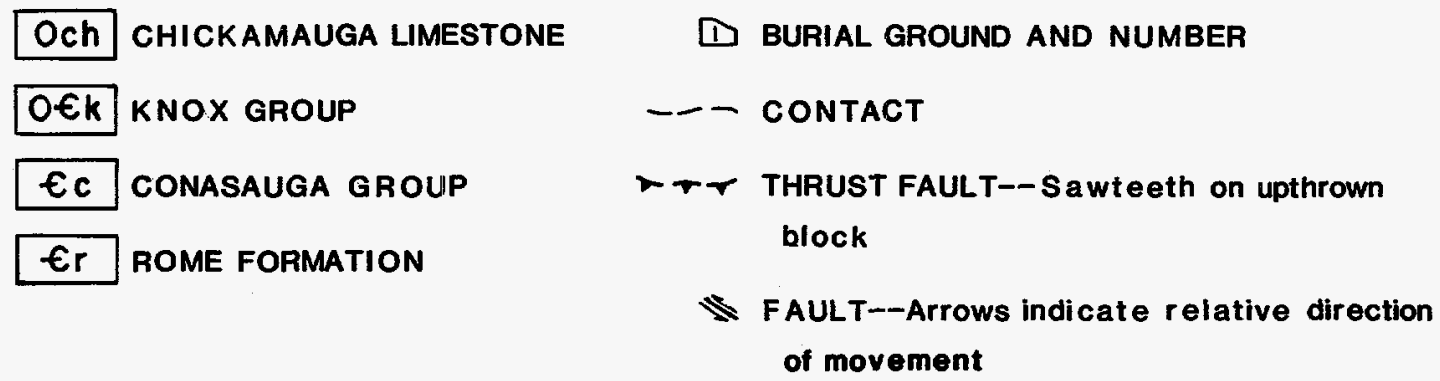

Figure 3.-Geologic map of the Oak Ridge National Laboratory area and section along line A-A'. 
shales interbedded with siltstone. Major constituents of the Rutledge Limestone are calcareous mudstone and shale, and limestone with clastic impurities. Mudstone and siltstone are interbedded with these rocks. Much of the Rogersville Shale is comprised of mudstones and siltstones. Geophysical logs show a distinct carbonate-rich interval about 5 -feet thick near the center of the Rogersville that has not been reported elsewhere. The Craig Limestone Member, another carbonate-rich interval found over a wide area of eastern Tennessee, occurs close to the top of the formation.

The lower part of the Maryville Limestone consists of calcareous mudstone interbedded with other clastic and impure carbonate beds. The upper part of the formation is more carbonate rich. It contains the thickest and purest carbonate beds underlying the burial grounds, with limestone beds as much as 10 inches thick having been reported at burial ground 5-south (Cowser and others, 1961, p. 9).

About four-fifths of the Nolichucky Shale is assigned to the lower shale member. It consists of cycles of mudstone or shale interbedded with limestone. The clastic components are the dominant lithology, particularly in the lower part. This lower member is overlain by a middle member, predominantly carbonate, and the upper shale member, consisting of calcareous mudstone interbedded with siltstones and carbonates.

The Maynardville Limestone is a transitional unit between the shale of the Nolichucky and the dolomite of the Knox Group, and consists of two carbonate members. The lower member is characterized by limestone with interbedded impure carbonate strata; the upper member, by oolitic and dolomitic limestone.

Bedding has considerable variability, both within a formation and from formation to formation, and has been described by such terms as thick, thin, wavy, lenticular, ribbon-like, bioturbated, planar, nodular and pelloidal.

The variable lithology of the middle and lower formations of the Conasauga is shown in figure 4 by the gamma and neutron logs of well OW-6, located in the center of Melton Valley near burial ground 5. Lithologic description, based on core from the Joy No. 2 well, has been added to the illustration. A close comparison of geophysical logs of wells in the waste-disposal areas often shows some degree of lateral change in lithology, even over relatively short distances. Many also show a thickening or thinning of beds. These are normal changes characteristic of the depositional environment. Logs examined of some wells are sufficiently different that they can not be correlated to specific intervals within a formation although the formation they represent can be identified. The difference in $\log$ responses may represent significant changes in facies or post-depositional structural adjustments such as folding or imbrication.

With the logs of several wells in the wastedisposal area, the contacts of the formations intercepted by the wells can be correlated, and those contacts projected to land surface to prepare an elementary geologic map of the area (fig. 5). The contacts shown on that map should be regarded as approximate in view of the inconsistency in angle of dip. The contact of the 


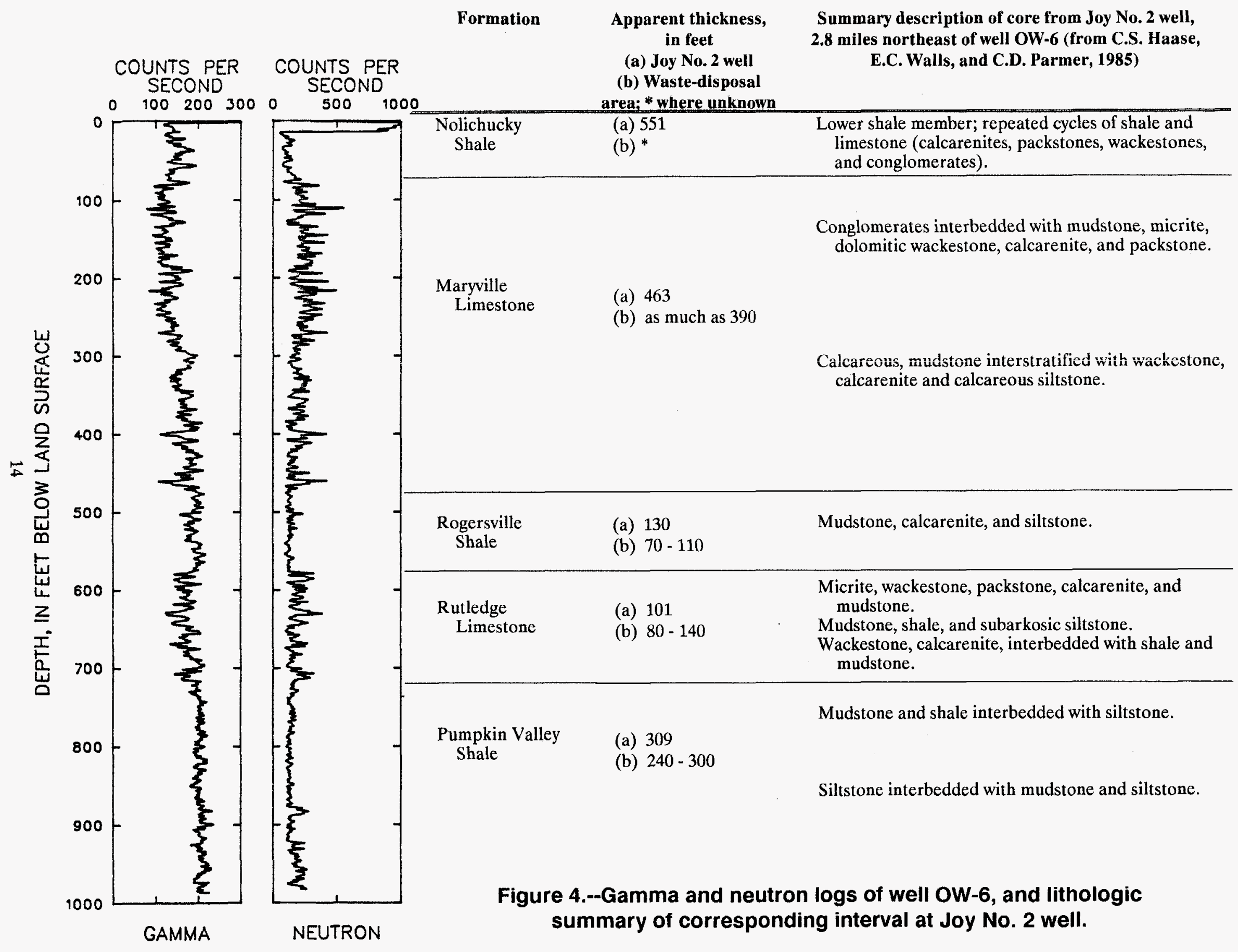


Nolichucky Shale with the Maynardville Limestone on the lower northwest slope of Copper Ridge is not shown on figure 5 because log or core data are not available for this area.

The geologic map is useful for determining the formations that underlie each clisposal site. Much of burial ground 4 is underlain by the Pumpkin Valley Shale; its southwestern extremity and possibly a small area near the drainage along its southern border are underlain by the Rutledge Limestone. The TRU area of burial ground 5 is underlain by the Rutledge Limestone and the Rogersville Shale. Much of the 5-south area of burial ground 5 is underlain by the Maryville Limestone; the low area near Melton Branch is underlain by the lowermost beds of the Nolichucky Shale. ILW pits 2, 3, 4, and ILW trenches 5 and 7 are underlain by the Maryville Limestone. Burial ground 6 is underlain by the upper Maryville Limestone and the Nolichucky Shale, although the location of the contact between the two formations across the site is tentative owing to inexact correlations between logs of only three wells at this site with those of well OW-6.

\section{STRUCTURE}

The predominant structural feature in the Tennessee section of the Valley and Ridge Province is a series of sub-parallel, northeast trending thrust faults. These faults have broken the substrata into a series of thrust blocks, with the block on the southeast overriding the adjoining block to the northwest. The trace of the Copper Creek fault, one of the regional thrust faults, traverses the northwest face of Haw Ridge (fig. 3) and extends across the width of Tennessee. Along this plane the Copper Creek fault block, which includes Melton Valley and the area to the southeast, was displaced northwesterly about 7,200 feet over the White Oak Mountain fault block, on which Bethel Valley has developed (McMaster, 1963, p. 19). As a result of spasmodic thrusting, the beds in the blocks were tilted to the southeast, and further broken and internally deformed by folds, faults, and other structural features of local extent.

It is these secondary features that are of hydrologic interest. Folds are a common, although inconsistent feature of the Conasauga Group through Melton Valley. They have been found in trenches excavated at burial grounds 4 , 5 , and 6, in drill core at the Four Acre Site and at proposed burial ground 7, in pits at the ILW area, and in exposures along road cuts. The folds vary in type, intensity, and continuity. The strata most affected are the thin-bedded shales and mudstones, but all lithologic types have been deformed to some degree.

Joints and fractures are prevalent. Joints are particularly associated with the shale and siltstone strata. While fractures are found in all of the lithologies present, small-scale fractures are particularly common in the thicker, carbonate-rich members. The degree of joint openness may be related to lithology. Haase and others $(1985$, p. 63$)$, in examining core from the Joy No. 2 well, noted that joints in limestone and siltstone were partially to completely filled by secondary mineralization. Fractures in the limestone units are the most likely to be filled by secondary mineralization. 
Faults are a common structural feature of this area. Perhaps the most common type of fault are the bedding faults where beds have slid over each other along bedding planes. These faults are particularly associated with the thin- and medium-bedded strata. They are evidenced by drag folds and other signs of disturbance in trench cuts; slicksided discs, mylonite zones, and rubble zones in core from deeper horizons; and televiewer logs of wells. There are also many high-angle faults of short length and displacement. Such faults have been observed in several shallow trench cuts in burial ground 6 , along the excavation for the French drain at that site (Davis and Stansfield, 1984, p. 41-53), and in core from deeper horizons elsewhere. Haase and others $(1985$, p. 60$)$ found this type of fault to be more abundant in the lower three formations of the Conasauga than in the upper three.

A transverse (or tear) fault appears to underlie the water gap through Haw Ridge and the Whiteoak Creek flood plain to the south. The fault is evidenced by the displacement of the formations to the east and west of Whiteoak Creek (fig. 5) and the non-alignment of the resistant peaks of the Rome Formation across the water gap (fig. 1). The displacement of the formations indicates that the east block moved northerly relative to the west block, whereas the non-alignment of peaks indicates the opposite relative direction of movement, which suggests that other complicating structural conditions are present. Haase (ORNL, written commun., 1981) has sugggested that the sub-block containing burial ground 5 has been tectonically rotated so that it is out of alignment with other areas of Melton Valley. To the east, Rothschild and others (1984a, p. 22) found that a series of thrust faults in proposed burial ground 7 resulted in the imbrication of strata at that site. To the west, deLaguna and others (1958, p. 106) believed that a fault, possibly a thrust fault related to the Copper Creek fault, lies to the south of the 200-foot wide belt of crumpled rock found at ILW pit 4 . Although yet unproven, it is thought that a few of the north-south tributary drainages that have been etched into the line of low hills on the northwest side of the valley may have developed over transverse faults that have broken the bedrock into additional sub-blocks.

The formations strike northeasterly at about 55 degrees; dip is to the southeast at angles commonly ranging from 20 to 25 degrees at the Four Acre Site (Barnett, 1954, p. 2) and from 30 to 40 degrees in the ILW area and at burial ground 6 (deLaguna and others, 1958, and Lomenick and Wyrick, 1965, p. 3, respectively). Rothschild and others (1984a, p. 30) reported a mean dip from 29 measurements of $23^{\circ} \mathrm{SE}$ at proposed burial ground 7. Because of the deformation of beds, however, there are many departures from the range cited, and locally the angle of dip may range from horizontal to vertical. On the limbs of folds dip may even reverse direction.

Dip also changes with depth. The overall trend is from an average dip of perhaps 20 to 25 degrees at land surface to nearly horizontal at a few thousand feet depth.

Dip between widely-spaced points can be calculated from stratigraphic correlations of the geophysical logs. The elevations of the Maryville-Rogersville contact and the RutledgePumpkin Valley contact at several wells were determined and dips were calculated for groups 
of three wells each by solving three-point problems (table 2). Dips in Melton Valley between the wells cited range from 14 to 18 degrees southeast. Dip determined by this approach includes the effect of compression of strata by folding and faulting as well as possible fault-block movement between the three points, and thus is expected to be somewhat less than dip measured at outcrops. The range in dips reported by the several studies reflects the structural complexity of Melton Valley.

Table 2.--Calculated approximate areal dip of strata in the waste-disposal area, based on contacts picked from gamma and neutron logs of wells

\begin{tabular}{|c|c|c|c|c|c|c|c|}
\hline \multicolumn{4}{|c|}{ Maryville-Rogersville contact } & & \multicolumn{3}{|c|}{ Rutledge-Pumpkin Valley contact } \\
\hline & Well nur & nbers & Approximate dip & & Well nut & abers & Approximate dip \\
\hline $400-5$ & $600-N$ & OW-6 & $16^{\circ} \mathrm{SE}$ & OW-6 & $400-S$ & $600-N$ & $18^{1} / 2^{\circ} \mathrm{SE}$ \\
\hline $400-S$ & 469 & OW- 6 & $14^{1} / 2^{\circ} \mathrm{SE}$ & OW-6 & $400-S$ & E-362 & $18^{\circ} \mathrm{SE}$ \\
\hline $400-5$ & $600-N$ & 113 & $16^{\circ} \mathrm{SE}$ & OW- 6 & $600-N$ & E-362 & $18^{\circ} \mathrm{SE}$ \\
\hline $465^{\star}$ & OW-6 & 114 & $17^{\circ} \mathrm{SE}$ & & & & \\
\hline
\end{tabular}

*Depth of contact estimated.

\section{HYDROLOGIC UNITS}

The variations in lithology, differences in bedding characteristics, and innumerable folds, faults, joints, and fractures make the Conasauga Group a highly-complex hydrologic medium. In order to describe the two-dimensional and threedimensional movement of water below land surface, the geologic materials are divided into two hydrologic units, the regolith and the bedrock. They should not be conceived as two separate aquifers, however. The two units are hydrauli- cally connected with water moving from one unit to the other.

\section{REGOLITH}

The regolith is the mantle of decomposed earthen materials that rests on bedrock. It is in this unit that all of the radioactive solid waste at ORNL has been buried. 
clay and rock fragments, and less commonly, beds of rotten, shaley rock. In some of the topographically low areas of burial grounds 5 and 6 , the regolith is sufficiently weathered to have the appearance of brown soil.

Weathering characteristics lack uniformity. Generally, in the mudstone, shale, and siltstone beds, a transition occurs from the surface soil, through the rotten rock, and finally to bedrock. In the carbonate beds the transition is less gradual and, in places, abrupt. Beds of resistant, relatively unweathered rock may be present in either lithotype, particularly in the lower regolith. Where clastic and carbonate beds are interbedded, the lower regolith commonly has alternating hard and soft beds. Differential weathering with depth results in the absence of a sharp boundary between the regolith and the underlying bedrock, and adds complications to a definition of ground-water flow through this material.

The thickness of the regolith in this valley is related both to topographic location and lithology of the parent rock. The thickness generally is least below the low areas of the valley and greatest beneath the ridges. Its reported range is from 4 to 16 feet at burial ground 4 (Lomenick and Cowser, 1961, p. 8), a few feet to 40 feet at burial ground 5 (Cowser and others 1961, p. 7), and 5 feet or less to as much as 40 feet at burial ground 6 (Lomenick and Wyrick, 1965, p. 5). In the general area of the ILW pits regolith thickness is reported to range from 10 feet under the lowland to approximately 30 to 40 feet under the low ridges (deLaguna and others, 1958, p. 105).
Joints, fractures, partings and interstitial spaces in the regolith provide narrow pathways for the flow of water. The unevenness in extent of weathering, the lithologic variety of materials, and the presence of many structurally-related openings make the aquifer inhomogeneous and anisotropic. Natural inhomogeneity has been enhanced by the burial of a diverse assortment of loosely-packed waste materials that have become an integral part of the geologic media. Anisotropy has been magnified by trenches that extend below the water table and which transect the beds for substantial distances.

\section{BEDROCK}

Bedrock is the solid rock that lies below the zone of weathering. Some of the partings, joints, fractures, and faults in the regolith extend into the bedrock and, where open, enable the continued passage of water. Locally, the carbonate bedrock contains small solution channels caused by dissolution of the limestone by circulating ground water. Typically, dissolution occurs where these beds have been broken by fractures or faults. The extent of solution-channel development below the waste-disposal area is thought to be minor in relation to the mass of rock involved.

The volume of openings represented by joints, fractures, and solution channels per unit volume of bedrock is far less than that of the regolith and tends to decrease as depth increases. Earlier studies (deLaguna, 1956; deLaguna and others, 1958; Cowser and Parker, 1958; Cowser and others, 1961; Cowser, deLaguna, Parker, and Struxness, unpublished manuscript, 1961; 
unpublished report in USGS files about the Four-Acre site) concluded that most of the secondary openings in bedrock occur within 100 feet of land surface, and that very few openings persist to as much as $\mathbf{2 0 0}$ feet deep. Consequently, for the purpose of this study, 200 feet was taken as the lower limit of investigation by wells. More recent work (Haase and others 1985; this study) suggests that openings occur at greater depths, but below a depth of 200 feet, relatively little ground water is in circulation with that in the overlying network of openings. This is a result of the fewer openings as depth increases, the decrease in hydraulic continuity between openings, and the thinness of those openings under great overburden pressure. It is possible that relatively isolated, deeply cutting faults, if unfilled by secondary mineralization, may permit flow to greater depth, but if so, these are thought to represent minor flow paths and are beyond the scope of this study.

\section{GiROUND-WATER HYDROLOGY}

\section{LOCATION AND CONSTRUCTION OF WELLS}

Published and unpublished records indicate that more than 350 wells have been constructed in or near the Melton Valley burial grounds since the late-1950's. Many of these wells have been destroyed as the sites were developed, and others have been destroyed later by site maintenance. At this time (1985) about 245 wells remain where water-level measurements can be made.
The locations of wells in burial grounds 4, 5 , and 6 that have yielded data for this report are shown in figures 6,7 , and 8 , respectively, and the location of wells in the vicinity of ILW pits 2,3 , and 4 is shown in figure 9 . Figure 10 provides construction diagrams and lists characteristics of typical wells finished in the regolith and bedrock sections of the aquifer. Pertinent data of wells cited in this report are summarized in an appendix.

\section{HYDROLOGY OF THE REGOLITH}

\section{METHOD OF INVESTIGATION}

Water levels in the burial-ground wells were usually measured at 2 to 3 week intervals between 1975 and 1979. Additional measurements were made in burial ground 5 in 1982-1983 to include the newly constructed wells in the TRU area. The data of the regolith wells have provided the basis for preparation of hydrographs showing the pattern of water-level fluctuations at a large number of points in the burial grounds, depth to water maps, and water-table contour maps.

Slug tests were made of numerous wells in the disposal sites to determine a range of aquifer transmissivity and hydraulic conductivity. The method used differs from that described by Cooper and others (1967) and Papadopulos and others (1973) in that, instead of inserting a cylinder in a well to instantaneously raise the water level, a submerged cylinder was withdrawn from the column of water, causing an instantaneous drawdown of water level, and the rate of recovery was measured. Transmissivity and hydraulic 


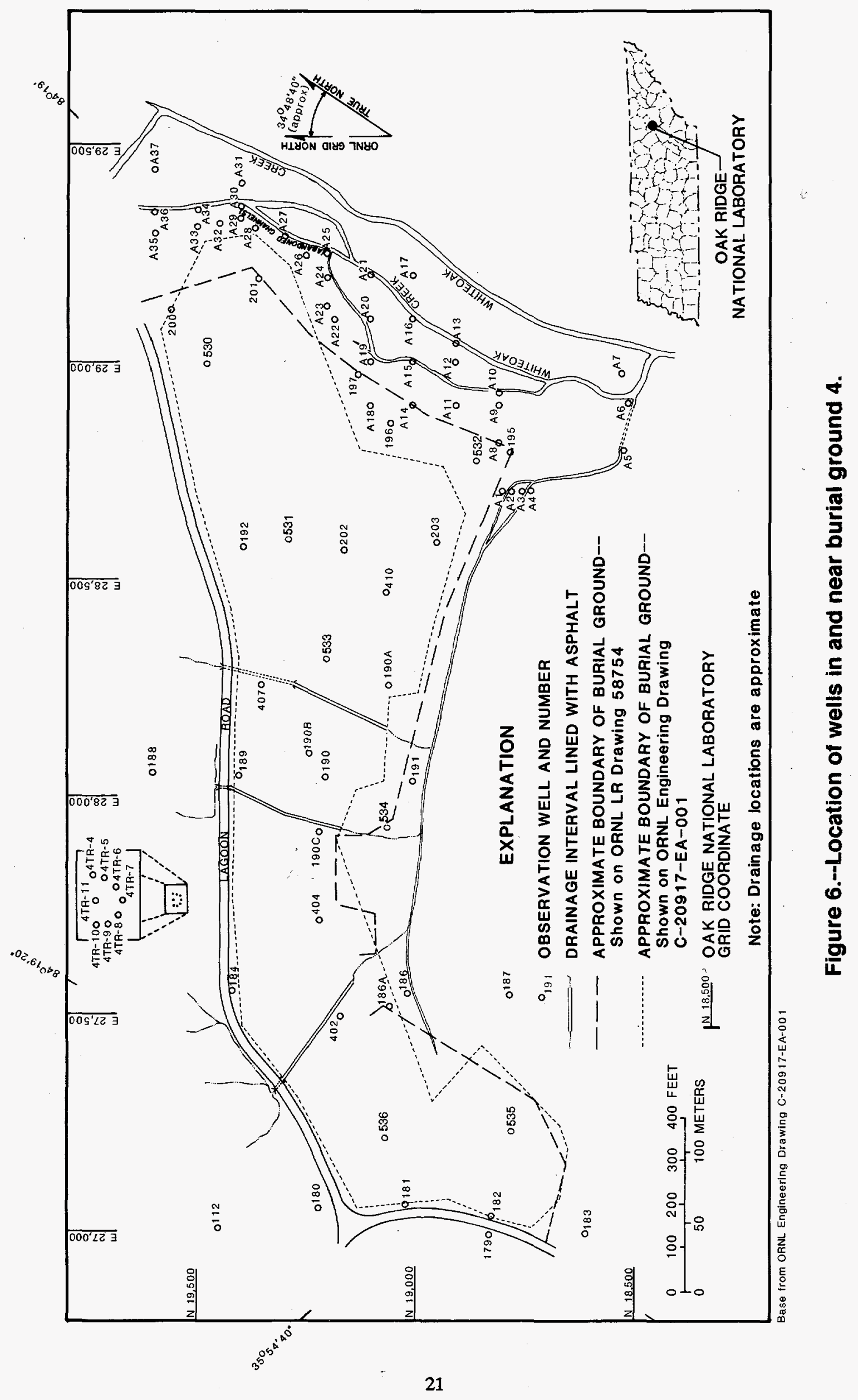




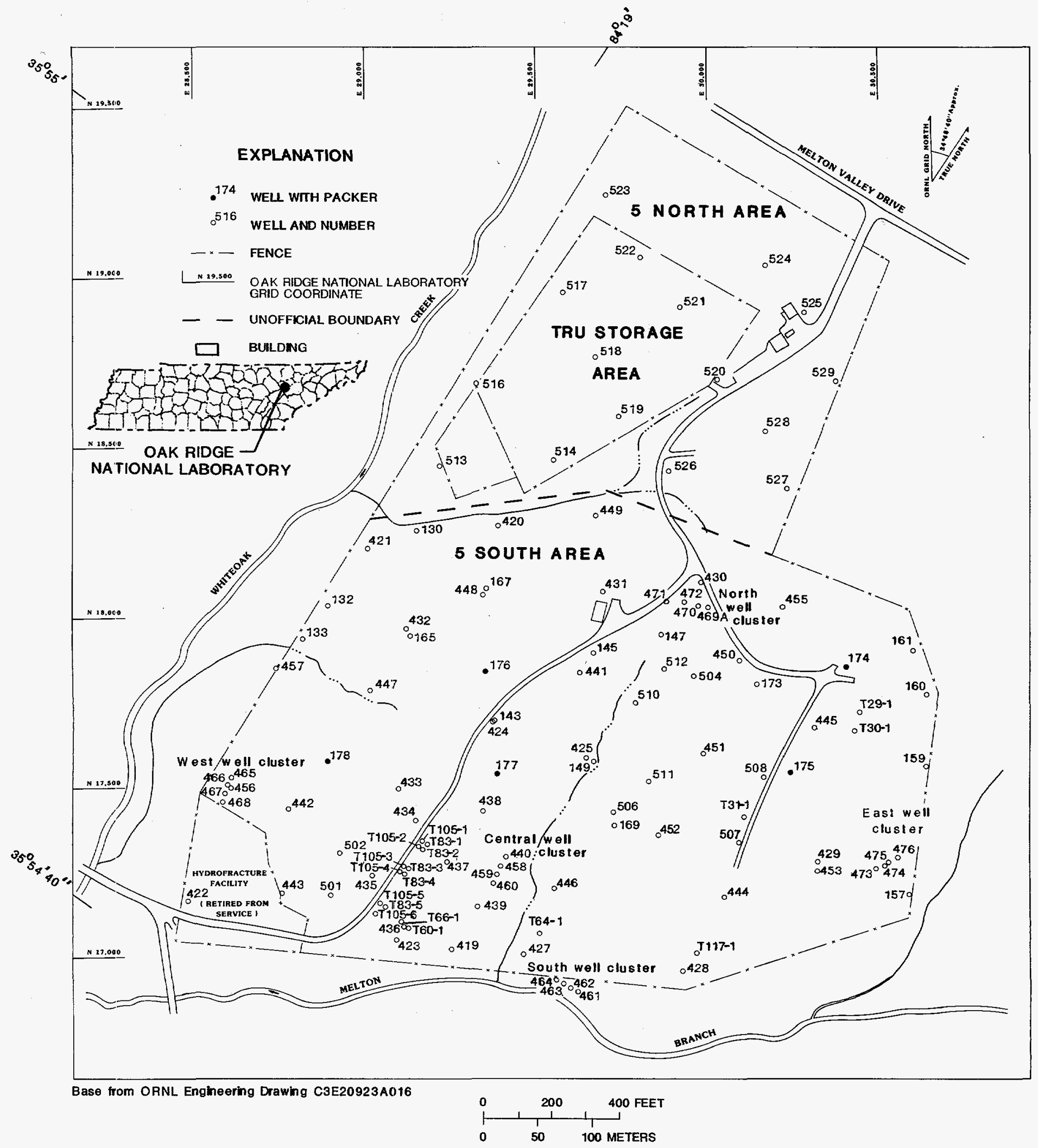

Figure 7.--Location of wells in burial ground 5. 


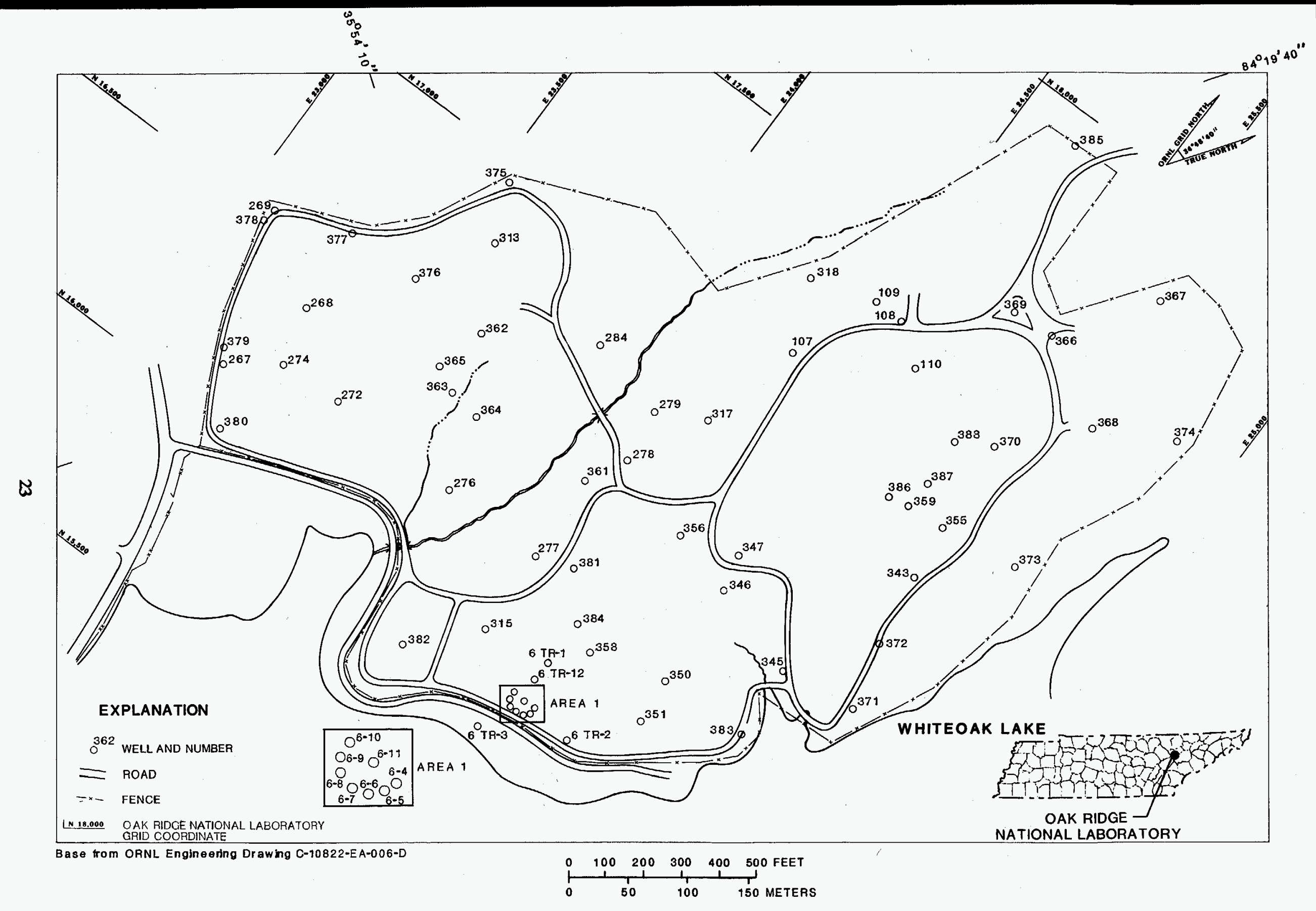

Figure 8.--Location of wells in burial ground 6. 


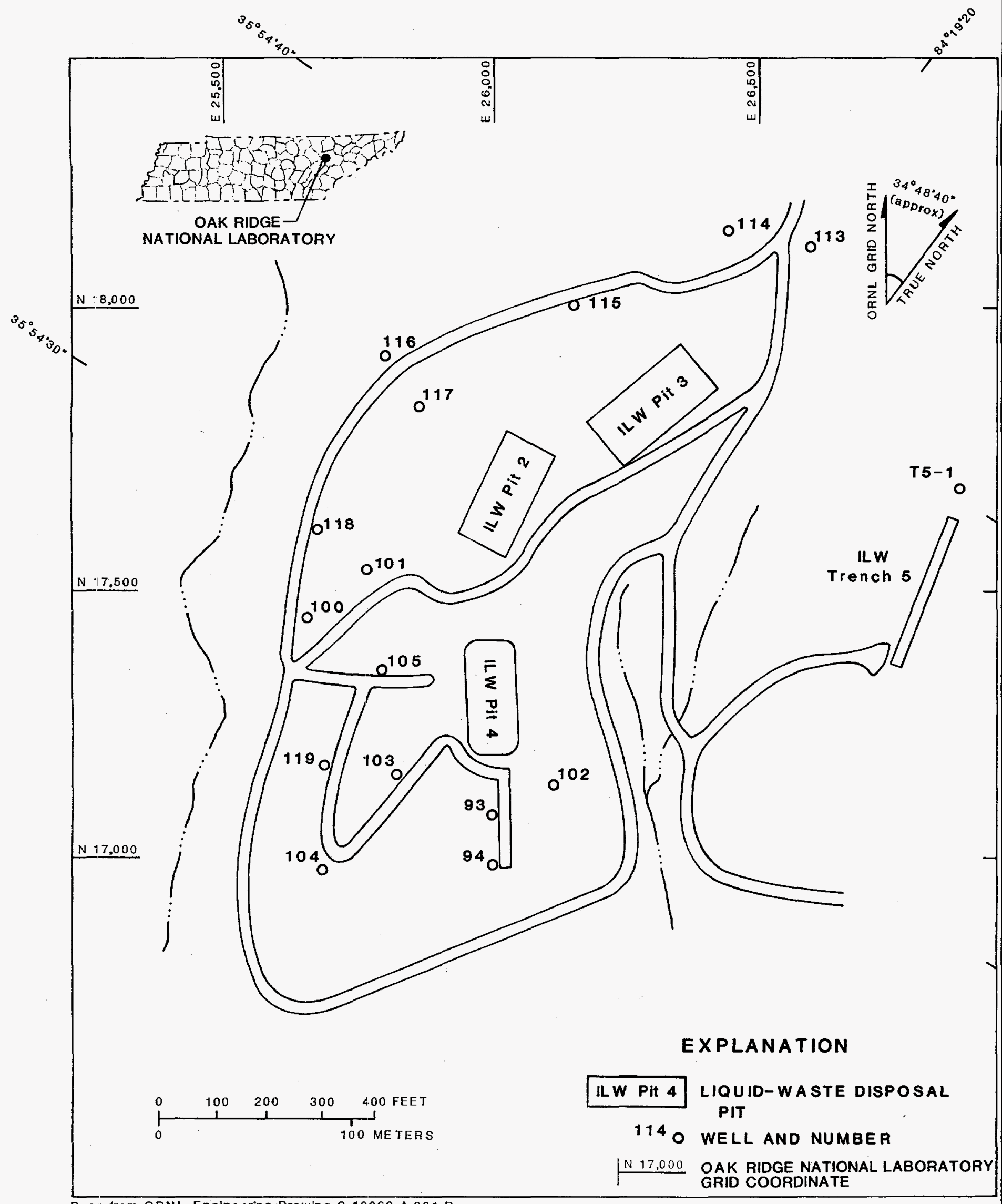

Bas $\Leftrightarrow$ from ORNL Engine ering Drawing $S-10063-A-001-D$

Figure 9.--Locaton of wells open to bedrock in the vicinity of intermediate-level liquid-waste (ILW) disposal pits 2, 3, 4, and ILW trench 5. 

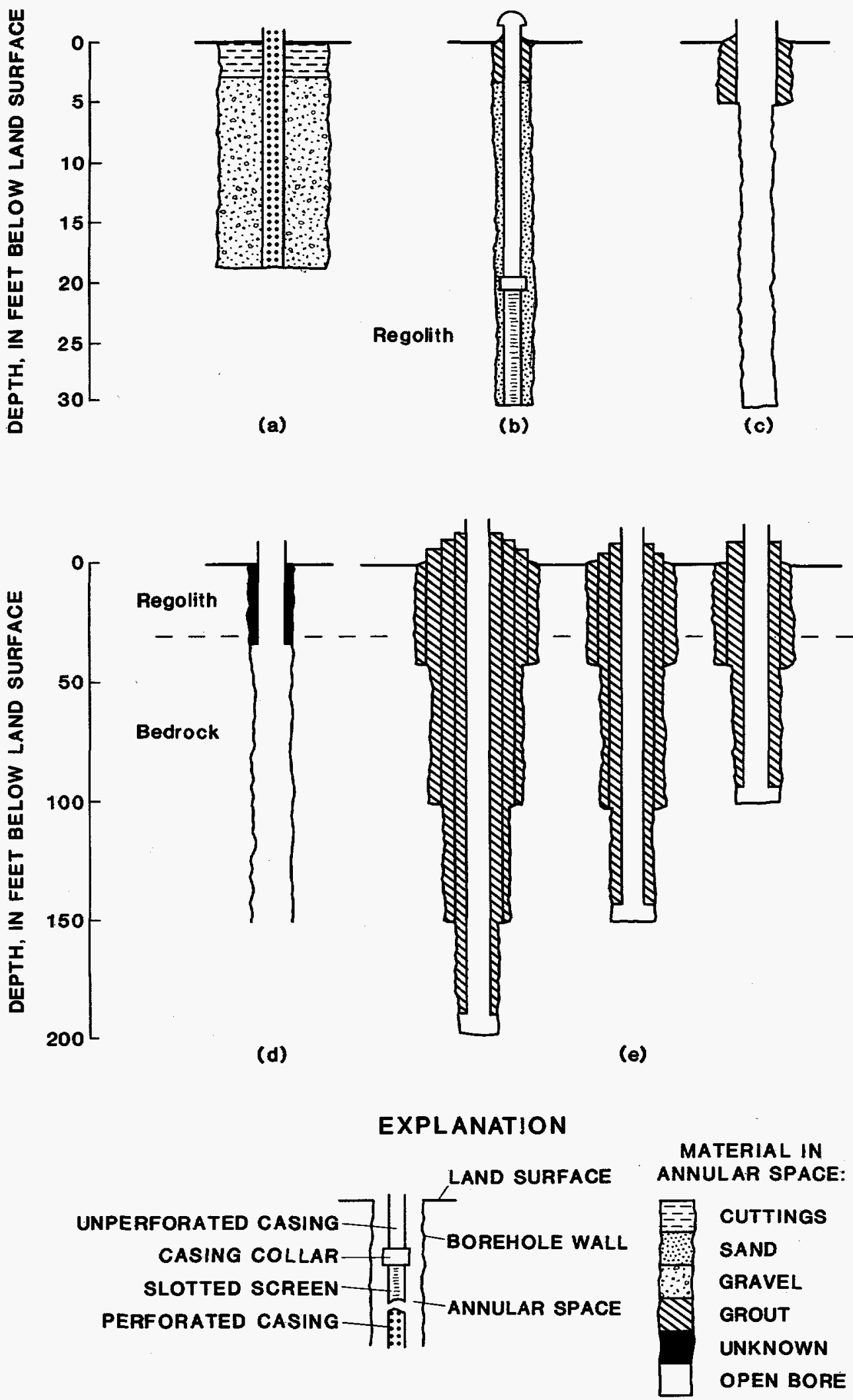

Depth of regolith/bedrock contact is for purpose of illustration only

Figure 10.--Construction diagrams of typical wells finished in the regolith $(a, b, c)$ and bedrock $(d, e)$. 
conductivity were computed after matching a curve based on the recovery data to a family of type curves. Because the approach falls short of measuring actual transmissivity or actual hydraulic conductivity of the aquifer for several reasons, subsequent references to these terms are as "apparent transmissivities" and "apparent hydraulic conductivities." ${ }^{2}$ In the tables that give the results, not all wells at each site are included. Some wells were not tested, some yielded data that could not be matched to the family of type curves, and the tests at a few wells were abandoned because the water-level recovery time was excessively long.

Ground-water tracer tests were successfully completed in two areas to test the thesis that weathering and jointing have sufficiently reduced the integrity of the regolith near the water table to permit the flow of water across the beds. This is in contrast to the concept of fluid movement that was developed by studies of the Conasauga Group during the 1950's and 1960's. Those studies concluded that most flow occurs in a direction parallel to formation strike, indicating that partings, faults and other small openings between beds provide relatively greater permeability than joints or fractures that cross the beds. The conclusions may be applicable to bedrock, but for reasons considered in the next section, their projection to fluid flow in the regolith should be made with care.

Relatively little was done during this investigation to obtain water-quality data of wells terminating in the regolith. This is in view of the Laboratory's program of sampling those wells, well construction characteristics that may adversely influence the analytical results, and unresolved issues about the shipment of potentially contaminated samples off-site to the Geological Survey's laboratory for analyses.

\section{CONCEPTUAL MODEL OF FLOW: THE REGOLITH}

The conceptual model of flow is based largely upon observation of the regolith's physical characteristics, the results of tracer tests performed as part of this study and those of other studies, investigations of fluid movement in the ILW-disposal area, and geophysical logs of wells.

Much of the bedding observed in trench walls in burial grounds 5 and 6 consists of deformed beds of rock fragments and clay. Much of the detritus observed from the construction of shallow wells in burial grounds 4 and 5 also consists of similar material. To the extent that the

\footnotetext{
${ }^{2}$ The reasons for a divergence in values are given here for the benefit of the reader who is considering similar tests in his work. Site conditions do not conform to the analytical assumptions of a homogeneous isotropic artesian aquifer confined above and below by impermeable strata having uniform thickness, and screened (or open) throughout its thickness; the water level at time zero of each test (which can not be measured unless transducers are placed in the well) was estimated by projecting to time zero a rate of change based upon subsequent water levels, rather than calculated by determining the volume of the cylinder withdrawn (for these wells the latter provides erroneous values because of irregularities in borehole diameter, the interception of solution channels by some wells, bridging of sand packs in the annular space of the smaller diameter wells, and unknown borehole diameter of some of the older wells containing gravel packs); the area of influence of each test is small and may be atypical of a more representative section of the aquifer; the data may be prejudiced if the section above or below the open zone in the well is anisotropic with regard to that of the open zone; and the amount of water-level change relative to the height of the water column can be substantial and, therefore, the constantly changing saturated thickness of the aquifer tested may influence the test results. Despite these shortcomings, the consistency in application of the method permits comparison of hydraulic conductivities among geologic units.
} 
decomposition of beds persists below the water table, it would be reasonable to expect that ground water flows between the fragments wherever a hydraulic gradient exists across the beds. This would indicate that the water-table gradient is the dominant factor controlling the direction of flow, rather than the orientation of openings between the beds.

To test the concept of flow as proposed, ground-water tracer tests were conducted on the hillside north of burial ground 4 and at the foot of a hillock in burial ground 6 . They are in areas that we now understand to be underlain by the lower Pumpkin Valley Shale and the lower Nolichucky Shale, respectively, although the shale at the latter site has a substantial carbonate component. At each site an array of eight shallow wells were constructed to permit the examination of flow parallel to strike versus flow normal to the water-table gradient in the weathered material. Tritiated water was used as the tracer at each of the arrays.

Analyses of samples from the observation wells at the site near burial ground 4 showed that the largest concentration of tracer moved across the beds in the direction of the water-table gradient. A secondary intermittent pulse of tracer was found in a well adjacent to one of the end wells, and the pulses correlated with occurrence of precipitation. In time, tracer was found in all of the observation wells. The results demonstrate that the beds in the regolith at that location are sufficiently weathered and jointed to permit passage of water across them. Yet the fractures and partings between beds also provide pathways for the flow of water, and during storm events, new heads and gradients are imparted to drive fluid between the beds as well as across them.

Analyses of samples from the observation wells at burial ground 6 also revealed that the largest concentration of tracer moved across the beds in the direction of the water-table gradient. Again, in time, tracer was found in all of the observation wells, although relatively little was found in one well adjacent to that in which the greatest amount was found, indicating an impediment to flow at that point and demonstrating the anisotropy of the media. The finding of the largest concentrations of tracer at both sites in the well that parallels the water-table gradient and lies normal to the injection well (and formation strike) confirms the test hypothesis that the integrity of the regolith has been reduced by weathering and jointing to permit the flow of water across the beds, and within the area involved, the water-table gradient rather than bedding orientation exerts primary control on the direction of fluid movement.

Somewhat different results were reported by Vaughn and others (1982, p. 53-58) for a small demonstration area in burial ground 6 . The site is near the contact of the Maryville Limestone and Nolichucky Shale. Using an homologous series of chlorofluorocarbons as a tracer, they found that the wells that lie generally parallel to the direction of strike from the injection well received the highest concentrations of tracer. They theorized that relatively rapid fracturetype flow occurred between the injection well and the observation wells, basing this conclusion on an attenuated arrival pattern of the tracer, an oval-shaped drawdown pattern upon subsequent pumping of one of the observation wells, a 
finding of two anticlines in the subsurface upon later excavation of a block of nine short trenches, and projection to this area of a strike-joint set that is associated with the Pumpkin Valley Shale (Sledz and Huff, 1981). They also suggested that some of the tracer traveled to the observation wells by intergranular flow, thus accounting for the attenuated pattern of arrival. Their work demonstrated that in this area the direction of flow is still strongly influenced by gradients within the underlying structural features, rather than the apparent water-table gradient as defined by water-level measurements in wells of that area.

The work of Olsen and others (1983) at ILW trench 7 also provides insight into the complexity of fluid movement in the Conasauga Group. They did not introduce tracers into wells, but studied the transport pathway of certain radionuclides in liquid wastes that were discharged to trench 7. A portion of the fluid later appeared in a seepage about 200 feet to the east; thus, in this area the waste fluid itself served as a tracer. Their field work revealed that the area between the trench and the seep (and probably beyond) is underlain by an east-west trending anticline that is bordered to both the north and south by fault zones. Analyses of water samples from several wells and examination of gamma logs of those wells led them to conclude that the fault zones represent significant pathways for the transport of radionuclides. They also concluded from the differences in water levels in wells across the fault zones, and the chemical constituents in water from wells in the fault zones, that there was little or no fluid movement across the anticline. Hence, this study also shows that fluid flow in some parts of the lower regolith is strongly influenced by structural elements and gradients within them.

Gamma logs of wells in this area provide additional detail about fluid flow. Those of wells drilled a decade ago to a depth of about 30 feet (approximately present water-table depth; the depth to the water table at these points during the time of trench operation is not known, but likely would have been somewhat less) encountered only low levels of radioactivity, but those of wells drilled more recently into the lower regolith or upper bedrock to a depth of about 50 feet encountered activity levels in the range of 10,000 to 20,000 counts per second. The logs have a serrated-like profile, indicating passage of a highly contaminated fluid between discrete beds rather than through the pores of a highly-weathered, granular-type medium.

The evidence from the numerous studies of the Melton Valley waste-disposal areas indicates that the saturated interval of the regolith has the flow characteristics of a porous medium in some areas, whereas in other areas it has some of the flow characteristics associated with a fracturedrock medium. This reflects the variable lithology, differing degrees of weathering in both the lateral and vertical directions, and structural complexity of the media.

Through much of the waste-disposal area, the beds at the top of the saturated interval have been reduced to heterogeneously-sized particles. With a porous medium of this type, fluids can move in any direction through the openings between the particles. The actual direction of flow is governed by the water-table gradient 
regardless of that gradient's orientation to the bedding.

In some places the beds at water-table depth, even when the water table is at its seasonal high, are only partly decomposed and have a low density of open joints or fractures. The beds thus become partial barriers to flow across them. Partings, which have developed along slippage planes between beds and which tend to be linear, provide the principal pathways for flow. The direction of flow is governed by the gradient within these openings, and may differ from that of the inferred water-table gradient based on contours of water-level data from wells spaced a few hundred feet apart. The actual flow paths could appear stair step, having segments oriented parallel to both the bedding and to openings that cross the beds, somewhat similar to that which might be expected in a fractured-rock medium.

Porous-media type flow may be characteristic of the entire column of saturated regolith underlying some areas. This probably is true of areas having an abrupt transition from regolith to bedrock. In other areas, fracture-type flow may increase in relative importance in the lower regolith as the completeness of weathering decreases, particularly as the water table undergoes its seasonal decline. There probably is a mixture of porous-media flow and fracturedrock flow in the interbeds of weathered shale and relatively unweathered limestone at the base of the regolith. Additional complications are introduced by faults which, as noted previously, may serve either as barriers to or conduits for flow, and by waste-filled trenches that penetrate the water table. The latter permit water to pass with some facility across beds that may have been partial barriers to flow. The resulting pathways of flow through the saturated regolith can vary from fairly direct to extremely tortuous.

To provide a generalized conceptualization of flow through media of this diversity, it may be helpful to portray flow direction as having two vector components and a resultant.

In areas that are void of unweathered beds or structural features that distort the flow pattern, a composite picture of flow through the regolith as suggested herein would show:

- A zone at and immediately below the water table where the largest vector of flow trends in the same direction as the inferred water-table gradient, especially during winter and spring when the depth to water is least. There also may be a small vector oriented parallel to the bedding. The relatively small angle between the resultant (the net direction of flow) and that gradient reflects the anisotropy of the medium.

- In some areas, an underlying transitional zone grading rapidly into bedrock where both inferred water-table gradient and bedding vectors have significant magnitude relative to each other. As the water table declines, the magnitude of the bedding vector relative to the gradient vector may increase. The resultant (the net direction of flow) may differ substantially from the 
gradient inferred from data of wells. This zone is absent where weathering to bedrock is complete.

In local areas having unweathered beds or certain subsurface structural features that influence the direction of ground-water flow, the largest flow vector follows the orientation of that feature. Such areas in the regolith of Melton Valley are thought to be subordinate in extent to those not having these features, but still represent a significant minority.

Most subsurface conditions that influence the pathways of water movement can not be readily discerned by simple field examination, and it is literally impossible if not impractical to conduct the number of ground-water tracer tests that would be required to characterize flow through numerous small segments of each burial ground. However, the general correspondence of watertable contours to topographic contours implies that the water-table gradient must be the primary control on flow through the upper part of the saturated zone at these sites. While the presence of concealed features that distort flow at indeterminable locations renders prediction of specific flow paths untenable, it appears that generalized, areal flow patterns in the regolith can be predicted by delineating the direction of maximum gradients on water-table contour maps of the disposal sites. On the maps that follow, broad arrows show the general direction of flow from areas of higher potential to those of lower potential, and to the inferred places of discharge. They have been drawn as if the aquifer is isotropic, even though it is apparent that differing degrees of anisotropy exist. Consequently, these flow directions are suggestive of flow patterns, and should be viewed as general rather than specific routes from point of recharge to point of discharge. A disadvantage of the contour maps is that they portray flow in only two dimensions, whereas flow in geologic media actually occurs in three dimensions. The reader should bear in mind that while much of the ground-water flow in the regolith occurs in the two dimensions shown, there is in addition a vertical component of flow in some parts of the disposal sites where the regolith is either supplying water to, or receiving water from, the underlying bedrock.

\section{BURIAL GROUND 4}

Ground water occurs under water-table conditions in the regolith of burial ground 4 . In many trenches, the water surface stands above the water table after periods of rain, and in some of the trenches containing alpha wastes, water is temporarily confined by the concrete cap over the waste. Water at shallow depth also occurs under confinement, with pressure only slightly greater than atmospheric, in some areas beneath the Whiteoak Creek flood plain.

During winter, the depth to water in wells within the boundary of the disposal site ranges from less than 1 foot to about 5 feet below the present land surface. During fall, it ranges from about 1 to 15 feet below land surface. Minimal depths are found along the southern and southeastern edges of the site, the three drainages that cross the central part of the site, and the low terrace containing wells 196 and 197 (on the east end) which is thought to be part of the original burial-ground surface. Maximum depths are 
found in wells along the southwest perimeter in the vicinity of the road to the ILW disposal area, and along the east end where a substantial thickness of highly-permeable construction debris that drains rapidly has been dumped over the trenches.

Annual fluctuation of the water surface in wells ranges from less than a foot in wells in the low-lying areas, to as much as 8 to 12 feet in wells near the west perimeter. The range in annual fluctuation in wells through much of the burial ground is 5 feet or less.

The depth to water on June 1,1978 , a time of year that may be considered typical of midseason conditions, is shown in figure 11 . If trench depth is 15 feet, it is apparent that water was present in all trenches in this burial ground on that date. Areas having the greatest thickness of saturated waste during mid-season are in the central and eastern parts of the site. Although the map shows as much as 10 feet of unsaturated material in some parts of the latter area, the waste is below the deposit of fill and therefore fully saturated. Data collected during other seasons indicate that a substantial part of the buried waste is saturated perennially.

Hydrographs of wells at and near the site reflect ground-water conditions of the area (fig. 12). The normal annual recovery and decline of the water table in an undisturbed area on the hillside north of Lagoon Road is shown in the hydrograph of well 188 . The softer and in some cases rounded peaks shown on the hydrograph of well 189 indicate receipt of water from nearby trenches and possibly from a lined drainage about 35 feet to the west. Departure from the norm of the well 186A hydrograph suggests that this well either terminates in a trench or is influenced by seepage from a trench close by. Perennially-saturated conditions very close to land surface are reflected in the hydrograph of well 196. Rapid drainage of the deposit of spoils and construction debris on the site's east end is shown by the absence of well-developed peaks in the hydrograph of well 201. The hydrograph also implies that the contact between the highly permeable spoils and the poorly-drained native material occurs close to the water surface in the well.

A low storage capacity of the regolith is indicated by the rapid rise and decline of water levels in undisturbed areas close to the burial ground. A water level rise of 1 foot or more per hour during intense, all-day storms has been found characteristic of the tracer-test wells. In these wells the annular spaces were grouted to a depth of 5 feet and, therefore, the change in water levels is believed to represent actual aquifer response. Water levels in wells in the western part of the burial ground where the depth to water may be 10 feet or more also respond rapidly to substantial rainfall events, but because of the construction characteristics of these wells, it is possible that the rise may be partly due to runoff entering the well rather than entirely to aquifer response.

Results of slug tests made in 14 shallow wells in and near the site are given in table 3. Apparent transmissivities range from $1.4 \times 10^{-1}$ to $1.2 \times 10^{1} \mathrm{ft}^{2} /$ day; apparent hydraulic conductivities range from $1.0 \times 10-2$ to $9.4 \times 10-1 \mathrm{ft} /$ day. 


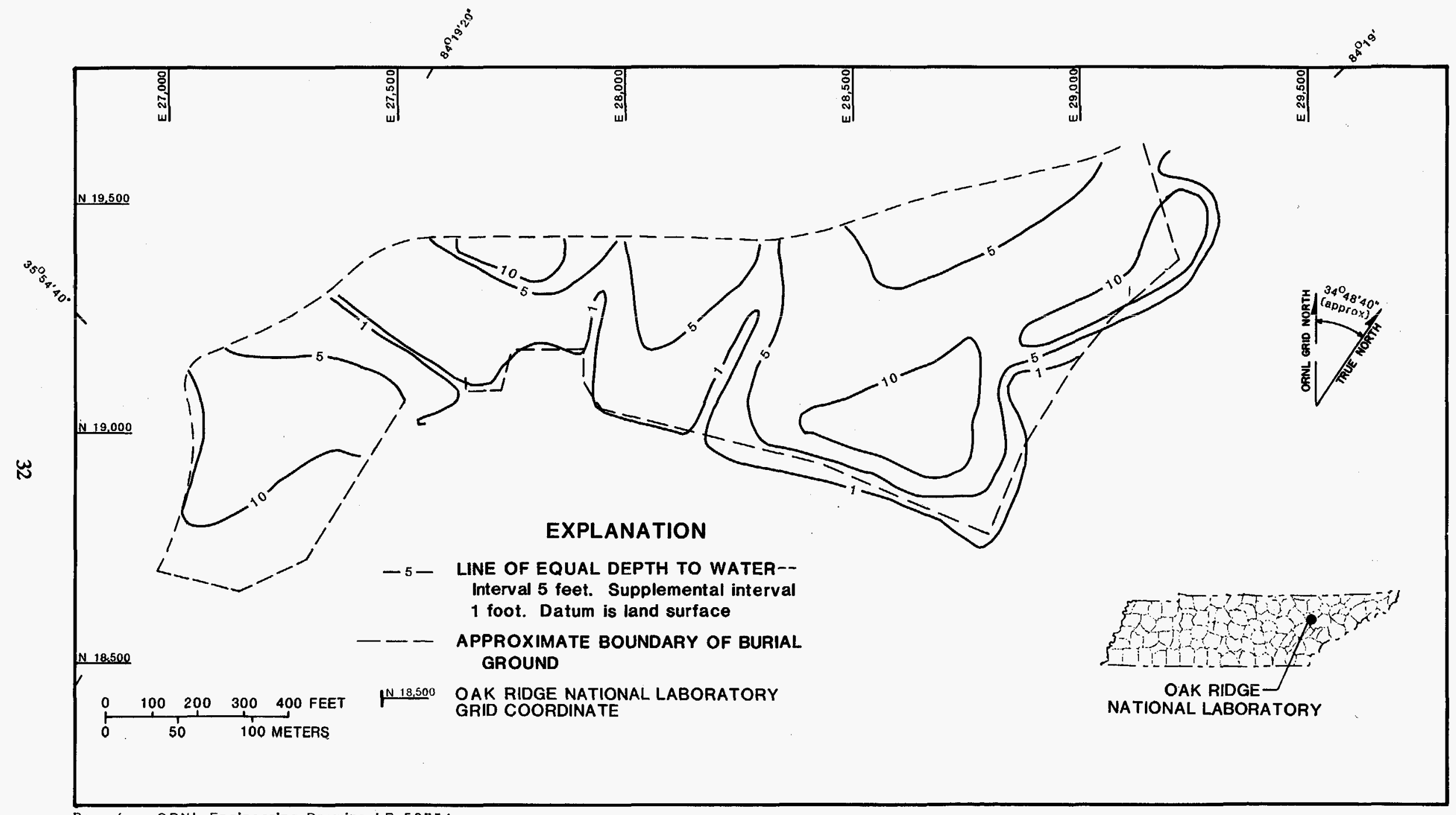

Base from ORNL, Engineering Drawing LR 58754

Figure 11.--Depth to water table at burial ground 4, June 1, 1978. 
WEU 188

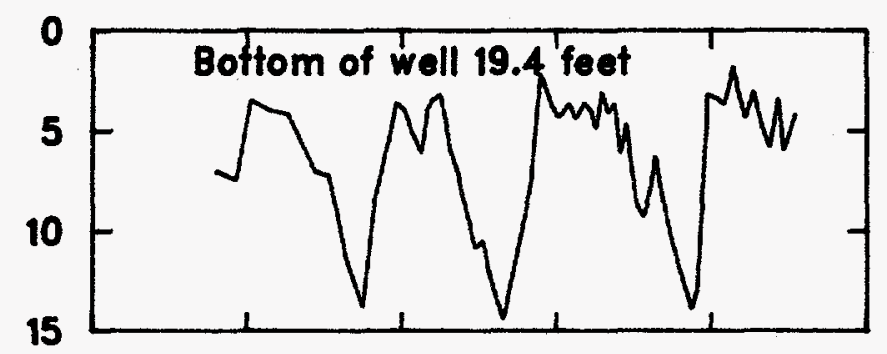

WEL 189
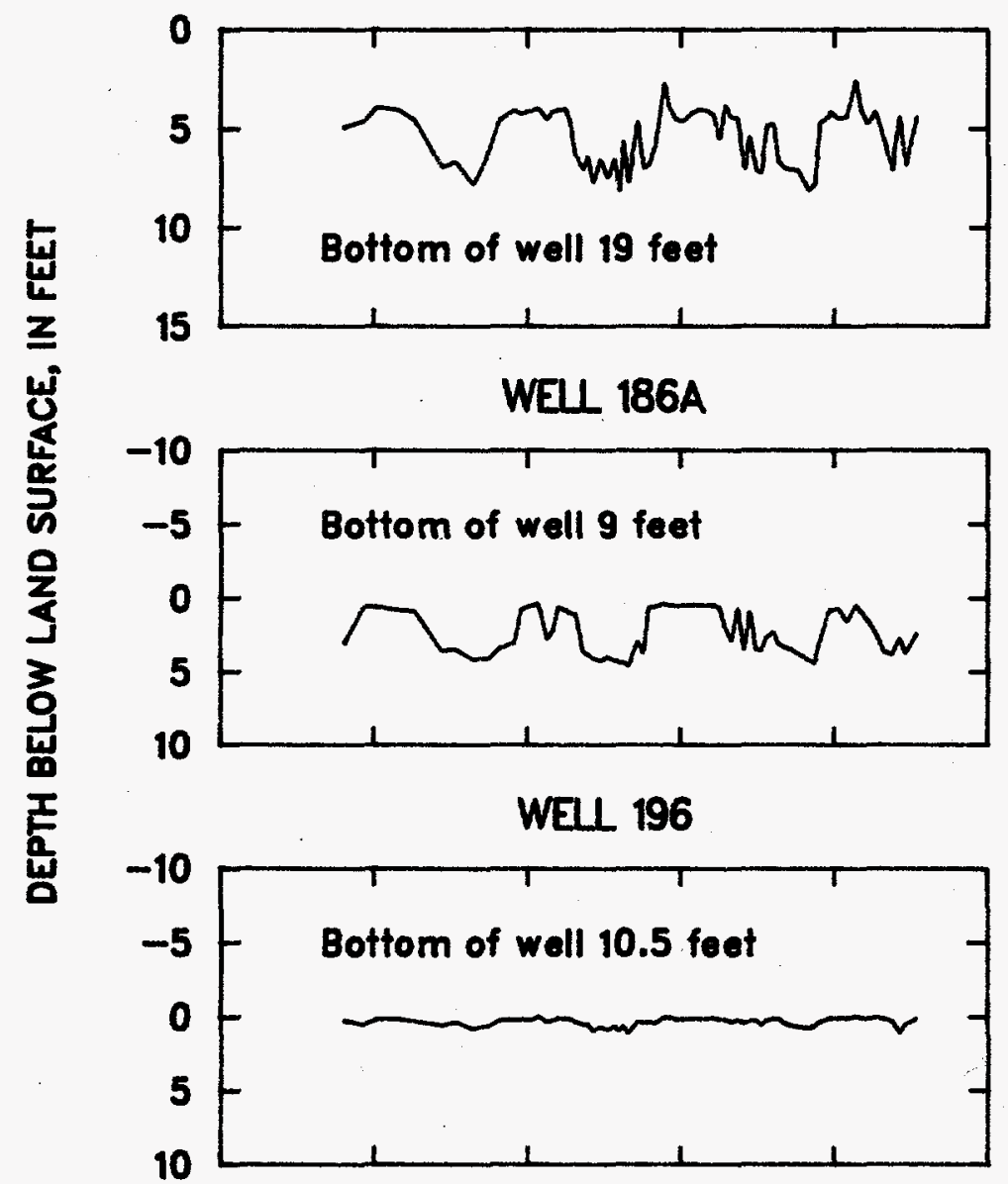

WEL 201

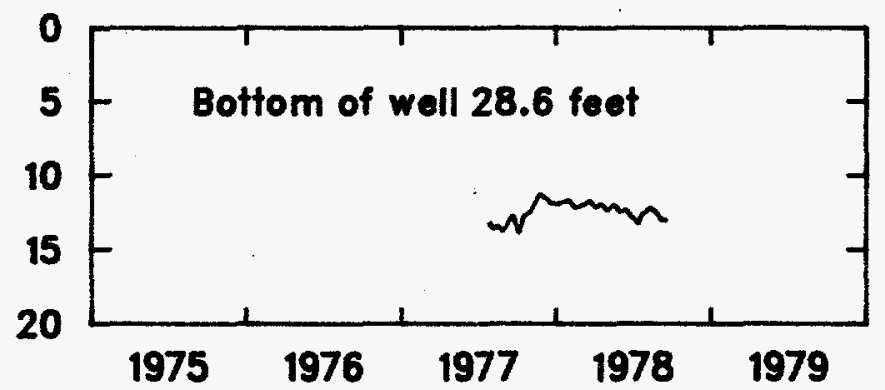

Figure 12.--Hydrographs of five wells illustrating ground-water conditions at burial ground 4 . 
Table 3.--Aquifer-test data of wells completed in the regolith at and near burial ground 4

[Formation: Crt, Rutledge Limestone; Cpvu, Pumpkin Valley Shale, upper member; Cipvl, Pumpkin Valley Shale, lower mumber; Queried (?), indefinite. Well is assigned to first formation designated for purposes of figure 19]

\begin{tabular}{cccc}
\hline Well No. & Formation & $\begin{array}{c}\text { Apparent } \\
\text { transmissivity } \\
\left(\mathrm{ft}^{2} / \mathrm{d}\right)\end{array}$ & $\begin{array}{c}\text { Apparent } \\
\text { hydraulic conductivity } \\
(\mathrm{ft} / \mathrm{d})\end{array}$ \\
\hline $4-4$ & $\mathrm{Cpvl}$ & $2.3 \times 10^{-1}$ & $1.2 \times 10^{-2}$ \\
$4-5$ & $\mathrm{Cpvl}$ & $3.6 \times 10^{-1}$ & $2.0 \times 10^{-2}$ \\
$4-6$ & $\mathrm{Cpvl}$ & $4.5 \times 10^{-1}$ & $2.3 \times 10^{-2}$ \\
$4-7$ & $\mathrm{Cpvl}$ & $5.7 \times 10^{-1}$ & $3.4 \times 10^{-2}$ \\
$4-8$ & $\mathrm{Cpvl}$ & $2.5 \times 10^{-1}$ & $1.0 \times 10^{-2}$ \\
$4-9$ & $\mathrm{Cpvl}$ & $5.2 \times 10^{-1}$ & \\
$4-10$ & $\mathrm{Cpvl}$ & $7.4 \times 10^{-1}$ & $2.5 \times 10^{-2}$ \\
$4-11$ & $\mathrm{Cpvl}$ & $1.4 \times 10^{-1}$ & $4.0 \times 10^{-2}$ \\
192 & $\mathrm{Cpvl} / \mathrm{Crt}(?)$ & $1.2 \times 10^{-1}$ & $1.6 \times 10^{-2}$ \\
203 & $\mathrm{Cpvv}$ & $2.9 \times 10^{-1}$ & $9.4 \times 10^{1}$ \\
& & & $1.8 \times 10^{-2}$ \\
531 & Cpvu & $2.2 \times 10^{-1}$ & $1.7 \times 10^{-2}$ \\
533 & Cpvu & $6.1 \times 10^{-1}$ & $2.4 \times 10^{-2}$ \\
534 & Cpvu/Crt (?) & 5.4 & $5.0 \times 10^{-1}$ \\
536 & Cpvu & $8.0 \times 10^{-1}$ & $3.9 \times 10^{-2}$ \\
\hline
\end{tabular}

To compare the aquifer's ability to transmit water in different geologic units, the hydraulic conductivities of the wells may be compared. Eight of the wells (4-4 through 4-11) are located within a 12-foot radius of each other on the hillside north of the site. Wells in this area and possibly well 192 were augered into the lower member (siltstone) of the Pumpkin Valley Shale that underlies the northeast sector of the disposal site. The other wells were augered into the upper member (mudstone/shale) that underlies the central part of the site. No wells in the southwestern sector, underlain by the Rutledge Limestone, were suitable for testing, but tests were made of a few wells in this formation in the TRU area of burial ground 5. The data do not show any substantial difference in hydraulic conductivity between the upper and lower members of the Pumpkin Valley Shale.

The ground-water reservoir below the burial ground is recharged by precipitation 
falling directly upon the site, runoff from Haw Ridge, and ground water flowing to the area from both Haw Ridge and the spiny ridge to the southwest.

The water-table contour map (fig. 13) indicates that ground-water below the site flows generally to the southeast and east, towards the south-boundary drainage and Whiteoak Creek. In the westernmost sector, the direction of flow changes sharply from north to southeast as water moves down-gradient to the drainage. Where the gradient crosses trenches, a large component of flow may be from one trench to another in the direction of the gradient.

Discharge from the aquifer is to the Whiteoak Creek drainage network. It is possible that a very small amount of ground water below the western perimeter of the site may discharge to a Whiteoak Creek tributary west of the ILW area. Ground water in the eastern third of the site, on a line from approximately well 192 to well 195 , discharges to the abandoned channels of Whiteoak Creek and possibly to the relocated main channel; water below the rest of the site discharges to the tributary along the south boundary. Discharge from the west half of the site occurs between wells 186 and 191. This area also is the terminus for two of the three surface drainages; the third drainage terminates a short distance east of well 191. Thus, this short stream interval receives a disproportionately large amount of the ground-water and surface-water discharge from the site and the upland area to the northwest. The map also suggests that discharge from part of the eastern quarter is focused on the terrace containing wells 196 and 197 . This appears to be borne out by the nearly perennially wet, swampy area in the vicinity of well 196 . It is likely that the sharp decrease in permeability along the contact between the fill and the regolith contributes to the discharge of water in this area.

Historically, several trenches have filled with water and overflowed at their low-end as "seeps" as this type of discharge is termed in the ORNL literature. The most common location of seeps has been in the vicinity of the three drainages that cross the site, the low terrace on the eastern end, and the slope to the west of well 186A. Occasionally, trenches in the general area between well 192 and 202 also have overflowed. After the three drainages crossing the site were lined in 1975, discharge from the trenches in that area was reduced substantially, but at least one new seep developed south of the point where the pavement terminated.

At least a few historic studies (Lomenick and Cowser, 1961; Gera, unpublished manuscript, circa 1964; Duguid, 1975, 1976) have shown that the discharge from seeps transports radionuclides originally buried in trenches. More recently, Huff and others (1982, p. 60-61) found that the highest concentrations of strontium-90 in the ground and surface waters of this site were in the area between the outfalls of the three lined drainages and the adjacent stream interval, and Huff and Farrow (1983, p. 84) found by analyzing cores of soil and regolith in this area that the highest concentrations of radioactivity are at land surface and decrease rapidly as depth increases. They concluded that trench overflow is the major mode of transport beyond this part of the burial ground, followed by overland transport to the south-side tributary. The relatively small discharge of water from seeps thus can 


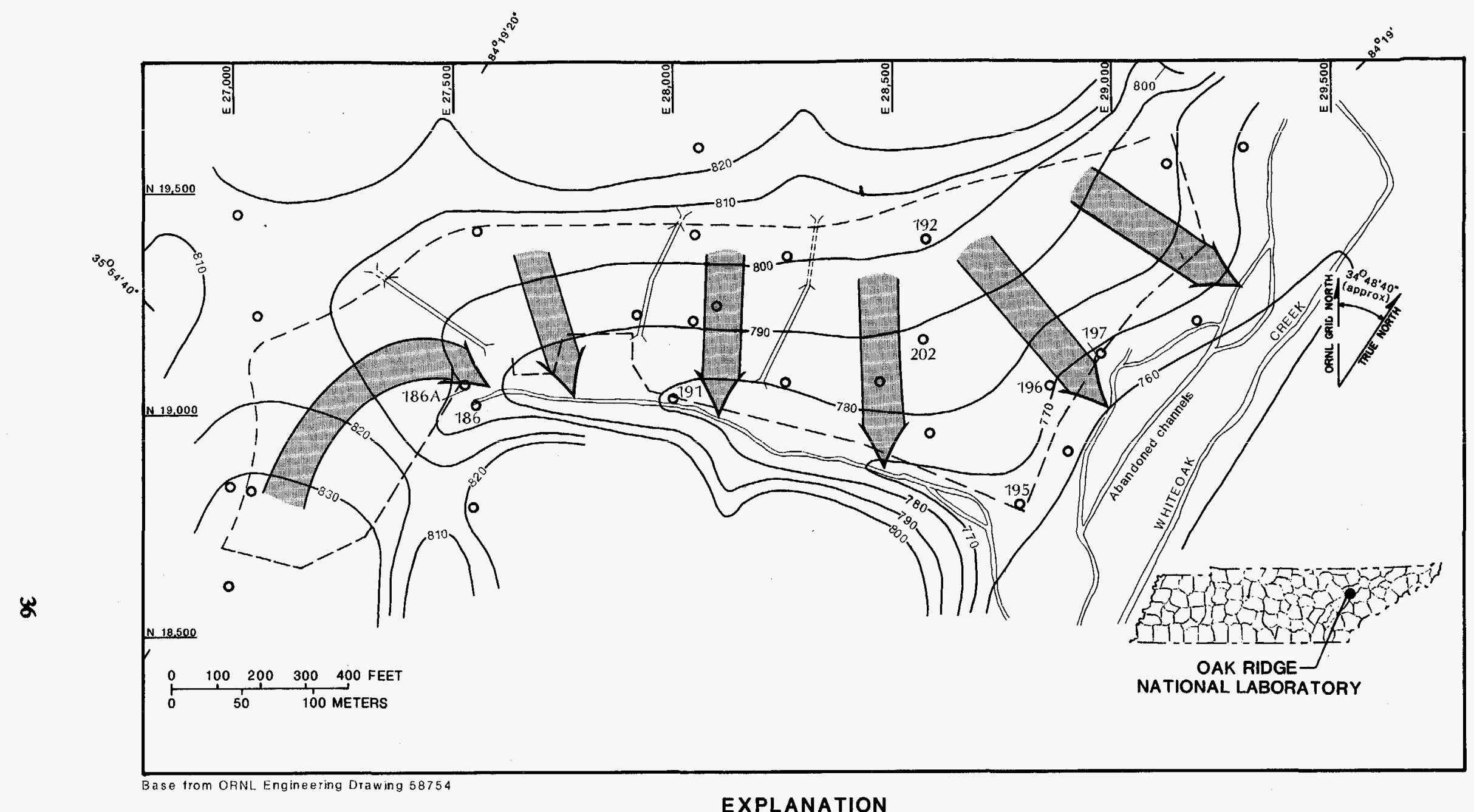

\section{EXPLANATION}

-760- WATER-TABLE CONTOUR--Shows altitude of water table. Contour interval 10 feet. Datum is sea level

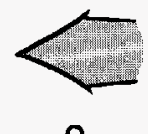

GENERAL DIRECTION OF GROUND-WATER FLOW IN REGOLITH

0

WELL--Selected wells identified by number

- - APPROXIMATE SITE BOUNDARY

$\Longleftarrow$ DRAINAGE--Asphalt-lined

$Y= \pm= \pm=*\{\quad$ CULVERT

IN 19,500 OAK RIDGE NATIONAL LABORATORY GRID COORDINATE 
represent as significant a transport mechanism for radionuclides as the larger discharge to the drainage system from the ground-water reservoir.

The low hydraulic conductivity values of wells in the regolith of the Pumpkin Valley indicate that flow velocity in that medium is low unless the slope of the water-table becomes quite steep. An approximate velocity for the midsection of burial ground 4 can be derived using the equation

$$
\mathrm{V}=\frac{\mathrm{Kdh}}{\mathrm{ndl}}
$$

where

$\mathrm{V}=$ average linear velocity,

$\mathrm{n}=$ effective porosity,

$\mathrm{K}=$ hydraulic conductivity, and $\mathrm{dh} / \mathrm{dl}=$ hydraulic gradient .

For this purpose, $\mathrm{K}$ is taken as $0.060 \mathrm{ft} /$ day (the geometric mean of the $\mathrm{K}$ values of 7 wells, taking the mean of the 8 tracer wells, $0.020 \mathrm{ft} /$ day, as a single well so as not to give that area disproportionate weight); $\mathrm{n}$ as 0.017 , calculated from the tracer test results; and $\mathrm{dh} / \mathrm{dl}$ as 0.068 , the gradient through the central part of the burial ground during mid-season. Calculated velocity then is about 0.24 foot per day. (For comparison, average velocity of the tracer, measured from the time of injection to the first peak in concentration, was 0.18 foot per day. Low concentrations of tracer also moved through fractures at a rate approaching 1 foot per day.) Thus, the time required for a particle of water to flow from Lagoon Road (fig. 6), entirely through undisturbed regolith underlying the site, to the south-tributary drainage may be in the order of 5 years. Actual velocity could be faster because of the slightly higher gradient during winter and the possibility of flow through fractures or other continuous pathways that have a hydraulic conductivity higher than average. Where flow through trenches results in spillage and subsequent overland flow, velocity can be many times more rapid than in ground water.

Although the full impact of the French drain constructed in 1983 along the northwest side of Lagoon Road is yet to be determined, one effect could be to decrease the average velocity of ground-water flow. Melroy and Huff (1985, p. 26) estimated that $141,000 \mathrm{~m}^{3}$ of water, or 66 percent of flow from the hillside northwest of the site, was diverted by the drain during calendar year 1984. Over a period of time, the water table may respond to this continued stress by dropping in elevation on the south side of Lagoon Road, thereby decreasing its gradient across the burial ground. With less driving force, ground water would traverse the site at a slower speed.

\section{BURIAL GROUND 5}

Ground water occurs in the regolith below burial ground 5 under unconfined, semiconfined, locally confined, and perched conditions. In most parts of the site, ground water is either unconfined, or confined under pressure only slightly greater than atmospheric where a bed of relatively unweathered rock locally excludes ground water. Hydrostatic pressures in these beds are insufficient to cause flow at land surface. One well (well 446), however, was augered into a small solution cavity, whereupon the well flowed for several minutes. This is the 
only shallow well in the burial ground that had sufficient pressure to cause flow.

Occasionally, shallow bodies of perched water occur where infiltrate is ponded on local remnants of unweathered rock. Such remnants have been structurally warped into local basins that catch and hold fluids. The current investigation found no areas of naturally perched water, but Cowser and others (1961, p. 10) reported water perched intermittently near three of the shallow wells constructed for their investigation. Trenches above the water table also contain perched water intermittently. The latter is an unnatural occurrence resulting from the relatively greater permeability of the earthen covers over the trenches than that of the regolith in which the trenches have been excavated.

The depth to the water table ranges from less than 1 foot to about 50 feet below land surface, and is related to both topographic location and season. The shallowest depths are found near the drainages; the greatest depths are found near the summits and ridges. At any location minimum depth usually occurs in winter and early spring. Water-table depth gradually increases to reach a seasonal maximum in late fall.

The range in annual fluctuation of the water surface in wells varies from less than 1 foot to a maximum of about 14 feet. Wells having minimal fluctuations usually are located near the drainages; those having maximum fluctuations generally are located in the upland areas of the site. Several exceptions to these generalizations show that topographic location is only one of several factors contributing to the magnitude of fluctuation.
The depth to the water table on July 14, 1983, superimposed upon a map of trench and auger-hole locations, is shown in figure 14. At that time of year water levels in most wells had receded slightly beyond their midpoint in annual fluctuation. The depth to water is 15 feet or less from land surface throughout a sizeable part of the southern and eastern areas of the disposal site. This is considered a critical depth because it is the reported maximum potential depth of trench excavation during the development of this site. (The maximum depth that holes were augered is reported to be 18 feet.) Trenches that are deeper than the depths shown by contours penetrate the water table, and typically during mid-summer have a column of water in them that is approximately equal in height to the difference between trench depth and contour value. Waste in them is buried in water to this level. In contrast, the depth to water at the highest points of the burial ground, which is where the wastes with the highest activity levels generally have been buried, was about 40 feet at that time. Assuming trench depths of 15 feet, these wastes rested about 25 feet above the water table on that date.

Minimum depth in winter varies from less than 1 foot at wells that are in low-lying areas to about 35 feet for wells situated in the highest parts of the burial ground. The 15-, 10-, 5-, and 1-foot depth contours for early winter correspond approximately to the location of the 20-, 15-, 10-, and 5-foot depth contours, respectively, of mid-summer. It becomes apparent that waste buried in trenches in the southern and eastern parts of the site is saturated during much of the year. In some of the lowest-lying areas, waste is saturated perennially. 


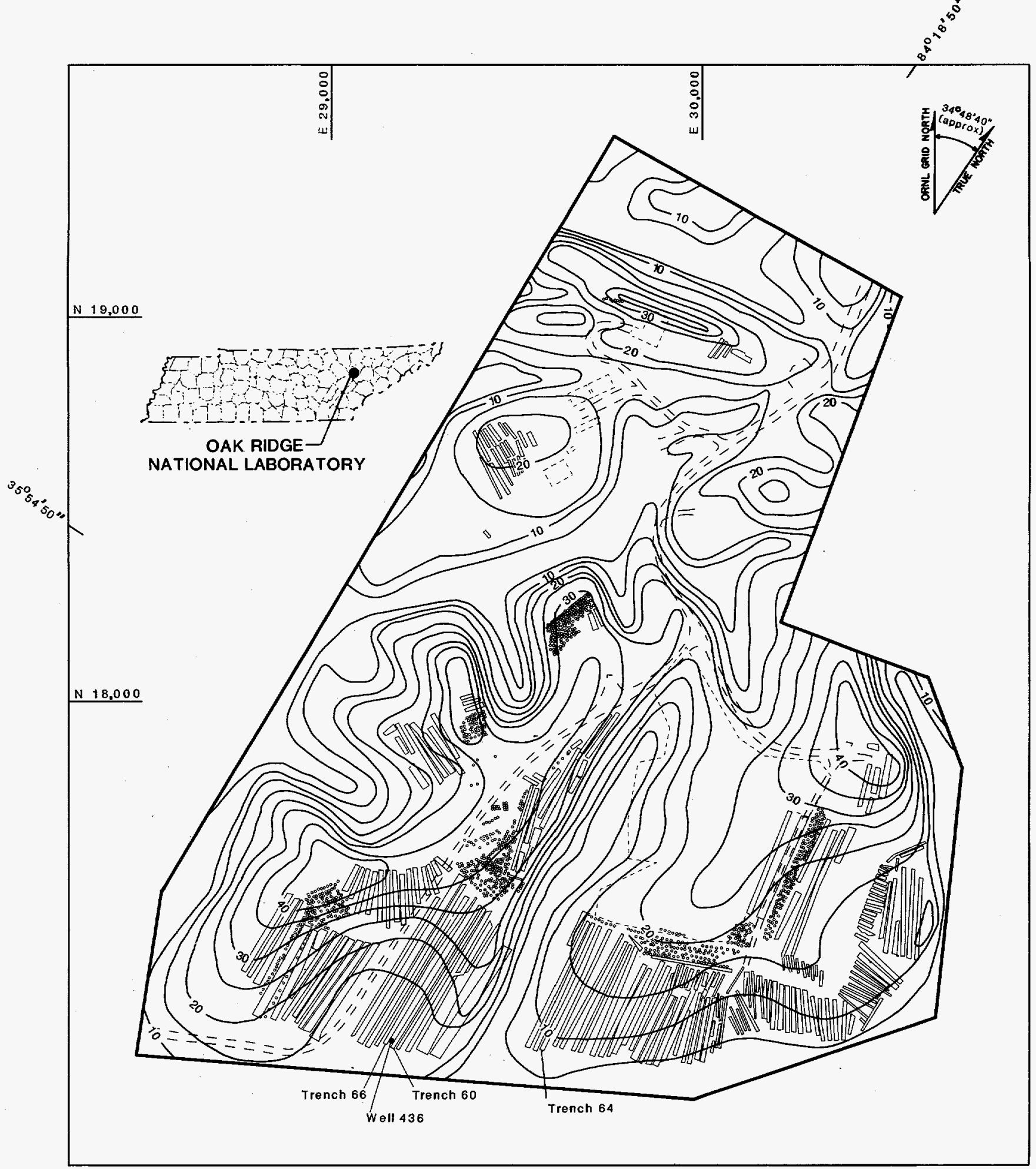

$\underbrace{0}_{0} 100 \quad 200 \quad 300400 \quad 500$ FEET

\section{EXPLANATION}

LINE OF EQUAL DEPTH TO WATER--Interval 5 feet. Datum is land surface

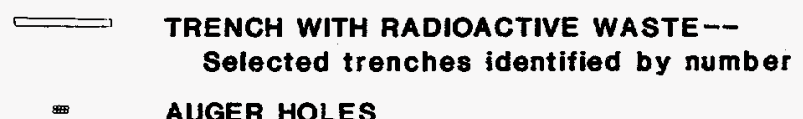

AUGER HOLES

Figure 14.--Depth to water table at burial ground 5 , July 14, 1983, and location of trenches, auger holes, and below grade waste-storage structures. 
Conditions of this area are reflected in the hydrographs of the riser pipes, installed to trench depth, in trenches 60 and 64 (fig. 15). Trench 60 is on the south-facing hillside of the west lobe and is about 450 feet long. The hydrograph of the riser pipe in its low end shows that much of the waste in this trench undergoes seasonal saturation and de-watering. Its hydrograph corresponds closely to that of well 436 , augered into the septum between trenches 60 and 66 . The replication of hydrographs indicates that water in the trench is not just the result of infiltrate that has run down to and accumulated in the low end, but due to the trench's penetration of the water table in this area. The conditions in this trench are thought to be typical of other trenches in the west lobe.

Trench 64 is located on a more gentle slope of the east lobe. It is about $\mathbf{3 7 5}$ feet long, and is at a somewhat lower altitude than trench 60 . The hydrograph of the trench 64 riser pipe shows that waste in the lower part of the trench is saturated perennially. Continuous record (not shown) indicates that the water level responds quickly to storms, and with the more substantial rains, the trench fills with water to discharge fluid from its low end. This condition is typical of many of the trenches on the southeast side of the site. Discharge from many of the trenches in this area does not occur as seeps, but as shallow underflow near the contact of the undisturbed material and the thin deposit of permeable spoil placed on the former land surface.

Trenches on the higher ground also collect water during storm events, but none are known to overflow.
The numerous trenches with permeable covers throughout the site function as a network of infiltration galleries. They allow the subsurface to absorb more surface runoff from storm events than would occur under the natural forest conditions. This additional increment of recharge supplied to the ground-water reservoir, plus the reduced rate of transpiration effected by replacing the deep-rooted vegetation with shallow-rooted grasses, has resulted in a net rise of the water table and a decreased depth to water from the original site conditions.

The influence of geologic features upon aquifer characteristics is reflected in the hydrographs of all wells. For example, the normal annual rise and recession of the water table in an undisturbed area of the upland, underlain by limey shale of the lower to middle Maryville Limestone, is typified in the hydrograph of well 455 (fig. 16). Note the serrated character of the record resulting from storm recharge filling the small volume of secondary openings in the aquifer on several occasions, and then quickly draining. This again reflects a low storage capacity of the aquifer. The hydrograph of well 450 , augered into the middle Maryville, is smoother, and reflects poor hydraulic connection with the aquifer, that is, the well intercepts very few secondary openings. The slug test of this well was abandoned because of the very slow water-level recovery. The hydrograph of well 438 in the relatively lime-rich upper Maryville also is comparatively smooth, but this well intercepts a greater volume of joints, fractures or other openings that enables this part of the aquifer to assimilate recharge without the rapid rise and decline characteristic of the well 455 area. The hydrograph of well 446, also in the upper Maryville, has a 


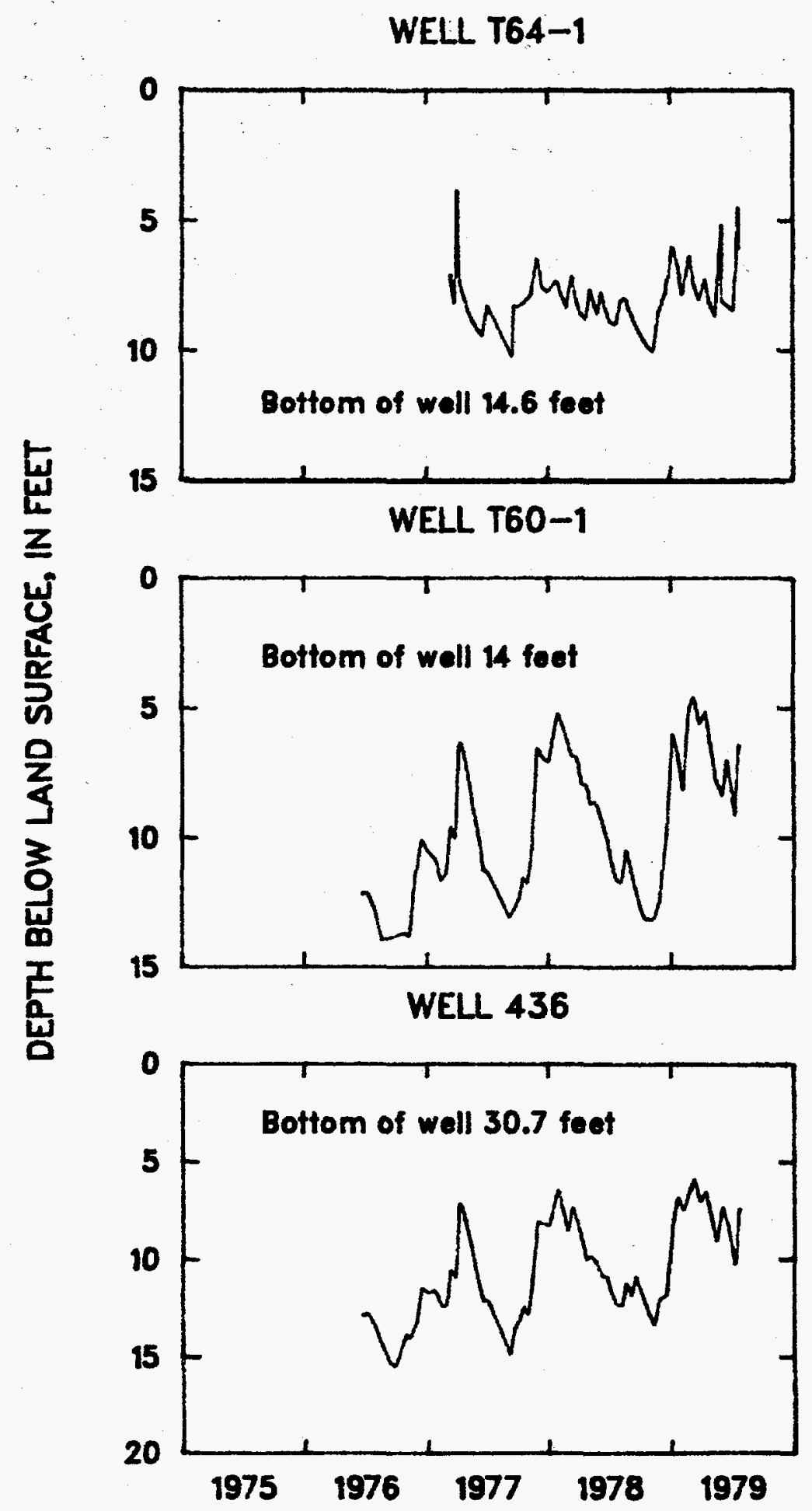

Figure 15.--Hydrographs for well 436 and riser pipes in trenches 60 and 64. 

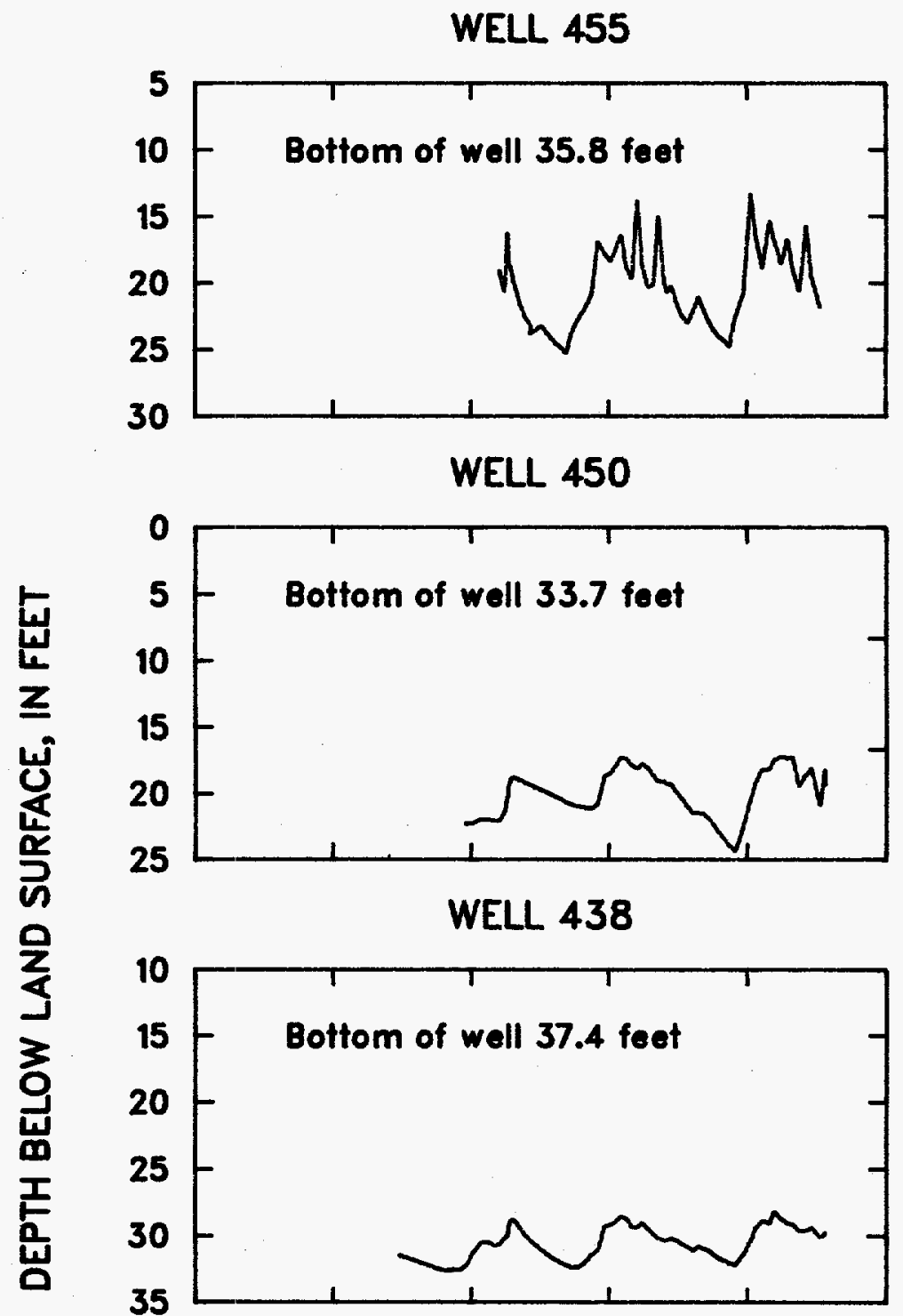

WELL 446

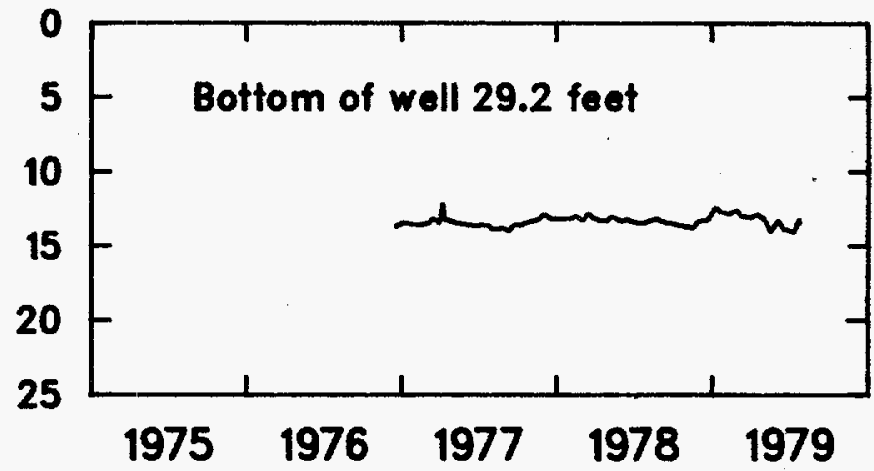

Figure 16.--Hydrographs for four wells illustrating aquifer characteristics at burial ground 5 . 
different pattern, and reflects the influence of a solution opening with artesian conditions.

Slug tests were completed in 30 shallow wells in the 5-north and 5-south areas. Most of the wells in the 5-north area were augered into the Rutledge Limestone and Rogersville Shale; two of the wells in this area (513 and 526) probably were augered into the lowermost Maryville Limestone. All of the wells in the 5-south area were constructed in the Maryville Limestone, except wells 436 and 464 which were constructed in the Nolichucky Shale.

Results of the tests are given in table 4. Apparent transmissivities range from $7.5 \times 10^{-2}$ to $53.6 \mathrm{ft}^{2} /$ day. Apparent hydraulic conductivities range from $2.9 \times 10^{-3}$ to $2.5 \mathrm{ft} /$ day. The lowest value is for well 522 ( 68 feet deep), and is more characteristic of the bedrock than the regolith. The geometric mean of the hydraulic conductivities, excluding that of well 522 , is $2.9 \times 10^{-1}$ $\mathrm{ft} /$ day. For purpose of comparison, Rothschild and others (1984a, p. 103) reported a geometric mean of $7.28 \times 10^{-2}$ feet per day of 12 wells at proposed burial ground 7 , which also spans several formations of the Conasauga, and Davis and others $(1984$, p. 84) reported a geometric mean of $1.79 \times 10^{-1}$ feet per day of 36 wells in the demonstration area of burial ground 6 . In both of these studies, the means included data of wells finished in both the regolith and the bedrock, and the analyses were done by the method of Hvorslev (1951).

Data of the burial ground 5 tests show no apparent relationship between the regolith hydraulic conductivity and the lithotype indicated by formation name. Values for both shale or limestone range from about $10^{-2}$ to $10^{0} \mathrm{ft} / \mathrm{day}$. This reflects the lithologic impurity of each formation despite its formation name, differences in extent of weathering, and depth of the saturated interval open to each well.

Qualitative judgment is required for estimating the coefficient of storativity (S) because the analytical procedure is insensitive to differences in $\mathrm{S}$. It is suggested that $\mathrm{S}$ values for much of the saturated part of the regolith likely fall within the range of $10^{-2}$ to $10^{-5}$. This is based on a match of a majority of the data curves of the slug tests to type curves of this magnitude, and is in general agreement with values found by other investigators (Davis and others, 1984, p. 83-86; Law Engineering Co., written commun., 1983) using both slug tests and other types of analytical approaches.

The water-table contour map of burial ground 5 (fig. 17) shows that the site has four primary ground-water recharge areas, and these correspond to the four lobate remnants etched out by the incision of drainages into the landscape: (1) the hill in the TRU area, (2) the hill along the northeast border of the 5-north area, to the east of the TRU waste-storage facilities; (3) the upper half of the east lobe at the 5-south area; and (4) the broad summit and surrounding area of the west lobe at the 5-south area. These areas generally comprise the upper two-thirds of the site.

The direction of flow probably is influenced to some degree by the orientation of the trenches. In the unsaturated zone, infiltration that is intercepted by sloping trenches can be channeled down the length of the trenches. 
Table 4.--Aquifer-test data of wells completed in the regolith at burial ground 5

[lFormation: Crt, Rutledge Limestone; Crg, Rogersville Shale; Cnl, Nolichucky Shale; Cimr, Maryville Limestone. Queried (?) where indefinite. Well is assigned to first formation designated for purposes of figure 19]

\begin{tabular}{|c|c|c|c|}
\hline Well No. & Formation & $\begin{array}{c}\text { Apparent } \\
\text { transmissivity } \\
\left(\mathrm{ft}^{2} / \mathrm{d}\right)\end{array}$ & $\begin{array}{c}\text { Apparent } \\
\text { hydraulic conductivity } \\
(\mathrm{ft} / \mathrm{d})\end{array}$ \\
\hline $\begin{array}{l}4: 32 \\
4: 33 \\
4: 34 \\
4: 35 \\
4: 36\end{array}$ & $\begin{array}{l}\mathrm{Cmr} \\
\mathrm{Cmr} \\
\mathrm{Cmr} \\
\mathrm{Cmr} \\
\mathrm{Cnl}\end{array}$ & $\begin{array}{l}1.5 \times 10^{-1} \\
11.2 \\
7.0 \times 10^{-1} \\
8.3 \\
13.6\end{array}$ & $\begin{array}{l}1.4 \times 10^{-2} \\
1.4 \\
5.8 \times 10^{-2} \\
3.8 \times 10^{-1} \\
5.3 \times 10^{-1}\end{array}$ \\
\hline $\begin{array}{l}4: 37 \\
4: 38 \\
4: 39 \\
440 \\
443\end{array}$ & $\begin{array}{l}\mathrm{Cmr} \\
\mathrm{Cmr} \\
\mathrm{Cmr} \\
\mathrm{Cmr} \\
\mathrm{Cmr}\end{array}$ & $\begin{array}{l}1.7 \\
6.4 \\
12.5 \\
9.8 \times 10^{-1} \\
10.2\end{array}$ & $\begin{array}{l}7.1 \times 10^{-2} \\
4.8 \times 10^{-1} \\
5.8 \times 10^{-1} \\
5.3 \times 10^{-2} \\
3.6 \times 10^{-1}\end{array}$ \\
\hline $\begin{array}{l}444 \\
445 \\
446 \\
447 \\
448\end{array}$ & $\begin{array}{l}\mathrm{Cmr} \\
\mathrm{Cmr} \\
\mathrm{Cmr} \\
\mathrm{Cmr} \\
\mathrm{Cmr}\end{array}$ & $\begin{array}{r}9.8 \\
17.3 \\
6.1 \\
20.4 \\
53.6\end{array}$ & $\begin{array}{l}6.6 \times 10^{-1} \\
4.4 \times 10^{-1} \\
3.4 \times 10^{-1} \\
2.1 \\
2.4\end{array}$ \\
\hline $\begin{array}{l}451 \\
452 \\
453 \\
455 \\
464\end{array}$ & $\begin{array}{l}\text { Cmr } \\
\text { Cmr } \\
\text { Cmr } \\
\text { Cmr } \\
\text { Cnl }\end{array}$ & $\begin{array}{l}35.2 \\
38.79 \\
8.3 \times 10^{-1} \\
9.0 \times 10^{-1} \\
6.7\end{array}$ & $\begin{array}{l}2.0 \\
2.5 \\
6.1 \times 10^{-2} \\
4.5 \times 10^{-2} \\
7.6 \times 10^{-1}\end{array}$ \\
\hline $\begin{array}{l}468 \\
472 \\
513 \\
514 \\
517\end{array}$ & $\begin{array}{c}\mathrm{Cmr} \\
\mathrm{Cmr} \\
\mathrm{Cmr} \\
\mathrm{Crg} / \mathrm{Cmr}(?) \\
\mathrm{Crt}\end{array}$ & $\begin{array}{l}3.3 \\
2.2 \\
3.3 \\
1.8 \\
3.2 \times 10^{-1}\end{array}$ & $\begin{array}{l}4.9 \times 10^{-1} \\
3.3 \times 10^{-1} \\
2.5 \times 10^{-1} \\
1.6 \times 10^{-1} \\
1.7 \times 10^{-2}\end{array}$ \\
\hline $\begin{array}{l}520 \\
522 \\
525 \\
526 \\
527\end{array}$ & $\begin{array}{c}\mathrm{Crt} / \mathrm{Crg}(?) \\
\mathrm{Crt} \\
\mathrm{Crt} / \mathrm{Crg}(?) \\
\mathrm{Cmr} / \mathrm{Crg}(?) \\
\mathrm{Crg} / \mathrm{Cmr}(?)\end{array}$ & $\begin{array}{l}16.7 \\
7.5 \times 10^{-2} \\
4.3 \\
2.5 \\
2.7\end{array}$ & $\begin{array}{l}7.1 \times 10^{-1} \\
2.9 \times 10^{-3} \\
3.3 \times 10^{-1} \\
1.2 \times 10^{-1} \\
1.9 \times 10^{-1}\end{array}$ \\
\hline
\end{tabular}




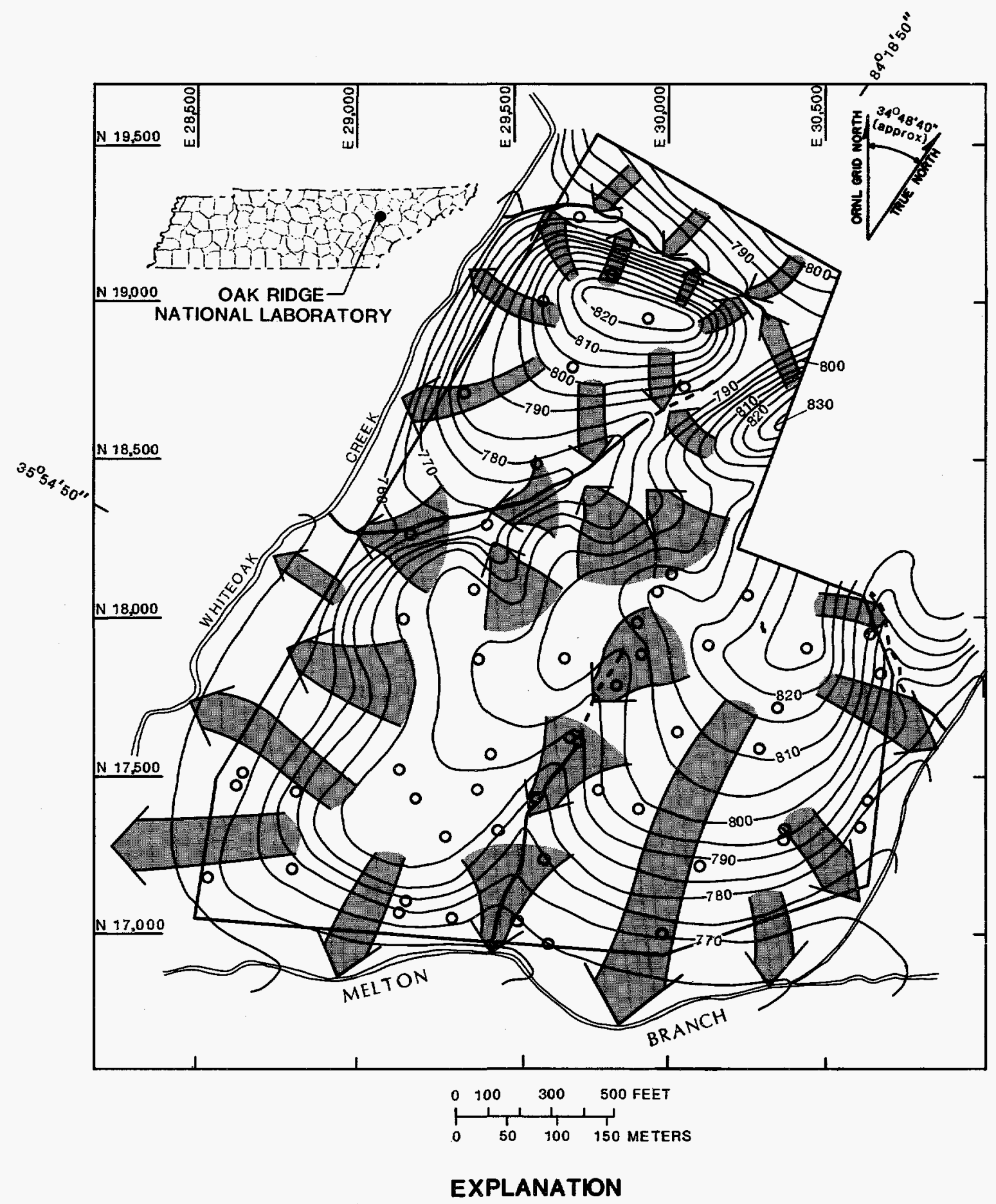

-790- WATER-TABLE CONTOUR--Shows altitude of water table.

Contour interval 5 feet. Datum is sea level.

- WELL

SITE BOUNDARY

DRAINAGE

GENERAL DIRECTION OF GROUND-WATER FLOW IN REGOLTH

IN 19,500 OAK RIDGE NATIONAL LABORATORY GRID COORDINATE

Figure 17.--Water-table contours at burial ground 5 for typical late, mid-season condition, July 14, 1983, and general direction of ground-water flow. 
Where trenches penetrate the water table, a particle of water may move through the reservoir in the trench and exit at any point of lower head within the trench. Flow may be from trench to trench where gradients cross trenches such as near the east boundary of the site. In the saturated zone below the trenches, flow occurs down gradient in the general directions indicated by broad arrows (fig. 17). In some areas, flow may be diverted locally to a direction more closely related to strike by gradients within concealed structural features.

From interpretation of the contours, it is inferred that ground water of this site discharges to Whiteoak Creek, Melton Branch, the unnamed tributary near the east boundary, and four drainages within the site. While a quantitative analysis of the map can not be made, there does not appear to be a concentration of discharge into any segment of the drainage as the contour pattern of the burial ground 4 map indicates. Discharge also occurs by trench overflow along the southside of the site. This water reaches Melton Branch either as overland flow or as shallow subsurface flow.

The only area where hydraulic potentials can be extended across the perimeter streams with available data is just west of the TRU wastestorage area into burial ground 4. Elsewhere, the potentials can be projected on the observation that at burial ground 5 and at all other areas studied in this valley, water-table contours generally follow topographic contours. With upland areas to the east, south, and west having higher potentials than that of the regolith around the perimeter of burial ground 5 , it can be reasoned that ground water from this disposal site cannot flow under the streams and travel to points beyond, but must discharge into these streams. Thus, these perimeter streams and their tributaries are thought to be the discharge points for ground water in the regolith of this site.

The velocity of flow can be estimated by using equation (1). For this computation, data of the 5-south area only are considered. Using the following values,

$K=0.35 \mathrm{ft} /$ day, representing the geometric mean of the hydraulic conductivities of wells in the 5-south area;

$\mathrm{n}=0.03$, derived from the ground-water tracer test results in burial ground 6; and

$\mathrm{dh} / \mathrm{dl}=0.05$, the average hydraulic gradient during mid-season, an average velocity of 0.58 foot per day is indicated. If a gradient more typical of winter conditions $(0.06)$ is used in the computation, the velocity increases to 0.69 foot per day. These values are in general agreement with those reported by studies (Davis and others, 1984, p. 77; Lomenick and others, 1967, p. 902) of other areas in Melton Valley underlain by equivalent geologic units. Assuming isotropic conditions and a gradient typical of mid-season, the time required for a particle of water to travel along the longest flow paths from the most distant point of recharge underlying buried waste to point of discharge in Melton Branch would be about 5 to 6 years. Actual travel time probably would be less because of the likelihood of intercepting fractures or other relatively highly-permeable zones en route, and the increased hydraulic gradient of winter. Since all other flow paths are of shorter distance, water 
traveling along them would discharge to the drainage system in some shorter period of time.

\section{BURIAL GROUND 6}

Ground water occurs under unconfined, semi-confined, and perched conditions in burial ground 6. Unconfined and semi-confined conditions are found throughout the site. Perched conditions have been found below the hill in the southwest corner of the site, below the hill along the southeast boundary, and occasionally in new trenches. It is likely that perched water also occurs temporarily in many of the closed trenches that are above the water table.

The depth to the water table is related to topographic location and season, as it is in burial ground 5. In winter, the depth ranges from essentially land surface along the drainages within the site to about 45 feet below the summit of the hill in the southwest corner. In fall, the range is about 1 to 2 feet to nearly 60 feet at these same locations.

Perched water occurs at shallower depths. Water is found in some of the shallow wells on the hill in the southwest corner of the site at as little as 5 feet depth after storms, and locally (well 351) at as little as 10 feet depth below the hill near the southeast boundary. Water commonly is perched above the water table in some of the trenches about 5 to 6 feet deep that contain compacted waste, located between wells 343 and 355. Water also has been reported perched in several of the trenches in the 49-trench area (in the vicinity of wells 107 and 317; Arora and others, 1981 , p. 20-25), although the liquid in many of these trenches could result from a seasonal rise of the water table.

The depth to the water table on May 31, 1978, a date typical of mid-season conditions, is shown in figure 18. Depth at that time of year is 15 feet or less through as much as half of the area within the burial ground. Wastes have been buried in this zone, but most of the trenches have been cut to depths of less than 15 feet. Some trenches in this area, however, are known to penetrate the water table seasonally, if not perennially. Most trenches between the 5-foot and 10-foot contours contain animal tissue having very low levels of radiation. Trenches with this category of waste are shorter, narrower, and shallower than those containing other forms of contaminated waste. Wastes with elevated levels of activity have been buried in the topographically higher areas of the site. These wastes rest in trenches generally about 10 to 35 feet above the water table.

Water levels in wells fluctuate from less than 1 foot to perhaps as much as 20 feet annually. Minimal fluctuations are associated with the wells near drainages; maximum fluctuations are associated with the wells on the hill in the northwest corner of the site. In the latter area this range includes perched water. Actual fluctuation of the water table below the higher areas of this hill is about 10 to 12 feet annually, and is the maximum water-table fluctuation for the site.

Hydrographs of the shallow wells in burial ground 6 generally resemble those of burial ground 5, and again reflect the lithologic and hydrologic properties of the aquifer. The character of the individual hydrographs commonly 


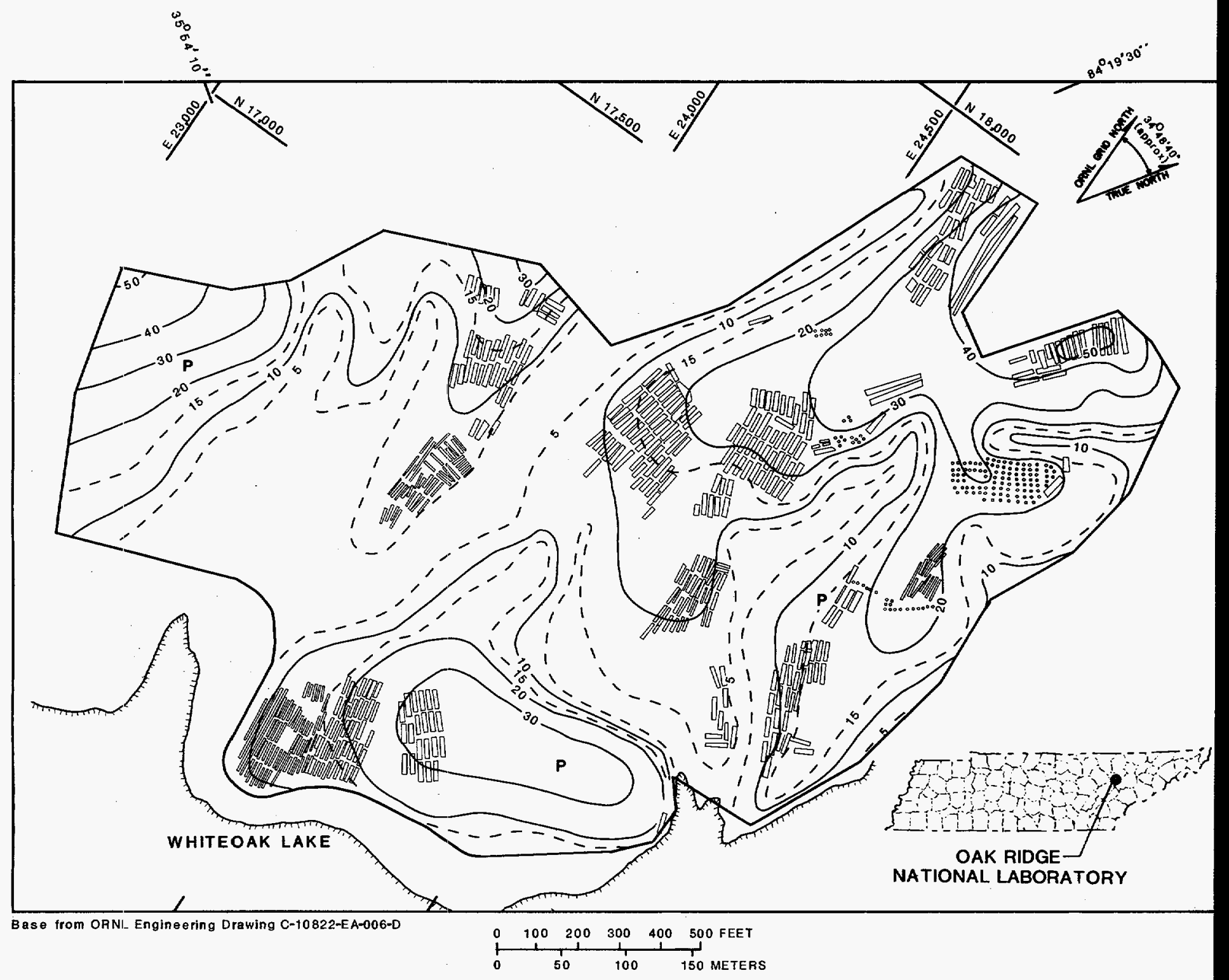

EXPLANATION

\begin{tabular}{|c|c|c|c|}
\hline$-5-$ & $\begin{array}{l}\text { LINE OF EQUAL DEPTH TO WATER-- } \\
\text { interval } 10 \text { feet. Supplementary } \\
\text { intervals at } 5 \text { feet and } 15 \text { feet. } \\
\text { Datum is land surface }\end{array}$ & $\because \because$ & $\begin{array}{l}\text { AREA WHERE WASTE HAS BEEN } \\
\text { BURIED IN AUGER HOLES-- } \\
\text { Pattern denotes areas, not } \\
\text { individual holes. Information } \\
\text { current }\end{array}$ \\
\hline \multirow[t]{2}{*}{$\mathbf{P}$} & $\begin{array}{l}\text { AREA WHERE PERCHED WATER } \\
\text { OCCURS AT SHALLOWER DEPTH }\end{array}$ & & SITE BOUNDARY \\
\hline & THAN CONTOURS INDICATE & $\mathrm{N} 17,500$ & OAK RIDGE NATIONAL LABORATORY \\
\hline & $\begin{array}{l}\text { TRENCH WITH RADIOACTIVE } \\
\text { WASTE--inforination current } \\
\text { through July, } 1985\end{array}$ & & GRID COORDINATE \\
\hline
\end{tabular}

Figure 18.--Depth to water table at burial ground 6, May 31, 1978. 
grades from one well to another, which probably reflects gradational changes in the lithology and the aquifer.

Slug tests were completed in 16 of 20 wells tested at this site. The wells were constructed into the Maryville Limestone and Nolichucky Shale. Results of the tests are given in table 5. Apparent transmissivities range from 1.2 to 68.2 $\mathrm{ft}^{2} / \mathrm{d}$; apparent hydraulic conductivities range from $5.6 \times 10^{-2}$ to $6.7 \mathrm{ft} / \mathrm{d}$. Taking the mean of the 6 wells (TR6-4 to TR6-10) in the tracer-test array as a single well so as not to give that area undue weight, the geometric mean of the hydraulic conductivities is $4.5 \times 10^{-1} \mathrm{ft} / \mathrm{d}$. This approximates that of burial ground 5's 5-south area, which is based upon data from nearly twice as many wells.

Data of the slug tests in burial grounds 4,5 , and 6 suggest that wells open to regolith derived primarily from shale formations have a lower hydraulic conductivity than wells open to regolith derived from limestone formations. This is

Table 5.--Aquifer-test data of wells completed in the regolith at burial ground 6

[Formation: Cnl, Nolichucky Shale; Cmr, Maryville Limestone]

\begin{tabular}{|c|c|c|c|}
\hline Well No. & Formation & $\begin{array}{c}\text { Apparent } \\
\text { transmissivity } \\
(\mathrm{ft} 2 / \mathrm{d})\end{array}$ & $\begin{array}{c}\text { Apparent } \\
\text { hydraulic conductivity } \\
\text { (ft/d) }\end{array}$ \\
\hline 368 & $\mathrm{Cmr}$ & 68.2 & 5.4 \\
\hline 371 & Cnl & 1.6 & $1.6 \times 10^{-1}$ \\
\hline 372 & Cnl & 2.6 & $1.3 \times 10^{-1}$ \\
\hline 37 & $\mathrm{Cmr}$ & 3.5 & $2.8 \times 10^{-1}$ \\
\hline 376 & $\mathrm{Cnl}$ & 17.3 & 2.2 \\
\hline 379 & $\mathrm{Cnl}$ & 3.2 & $3.0 \times 10^{-1}$ \\
\hline 380 & $\mathrm{Cnl}$ & 20.4 & 1.2 \\
\hline 381 & $\mathrm{Cnl}$ & 2.2 & $1.7 \times 10^{-1}$ \\
\hline 383 & $\mathrm{Cnl}$ & 1.9 & $2.2 \times 10^{-1}$ \\
\hline 385 & $\mathrm{Cmr}$ & 1.2 & $5.6 \times 10^{-2}$ \\
\hline $6-4$ & $\mathrm{Cnl}$ & 28.6 & 6.2 \\
\hline $6-5$ & $\mathrm{Cnl}$ & 33.3 & 6.7 \\
\hline $6-6$ & Cnl & 3.9 & 1.1 \\
\hline $6-8$ & $\mathrm{Cnl}$ & 12.5 & 2.4 \\
\hline $6-9$ & $\mathrm{Cnl}$ & 16.0 & 1.6 \\
\hline $6-10$ & Cnl & 8.3 & $8.6 \times 10^{-1}$ \\
\hline
\end{tabular}


illustrated by figure 19 , on which the apparent hydraulic conductivities of all wells in the three burial grounds that yielded data matchable to type curves are plotted on a logarithmic scale versus formation. The geologic map in figure 5 was used to determine the parent lithology for each well. It may be noted that the range in apparent hydraulic conductivities of wells in shale regolith is about the same as that in limestone regolith. It is significant, however, that the low end of the range is dominated by wells in areas underlain by the Pumpkin Valley Shale, a mud shale, and the upper end is dominated by wells both in the Maryville Limestone, which contains the thickest and purest carbonate beds underlying the burial grounds, and the Nolichucky Shale, which has a significant carbonate component within this area. Between these two ends, the values tend to intermix, and reflect the fact that the formations above the Pumpkin Valley are impure mixtures of lithified mud and lime. A clear relationship between hydraulic conductivity and lithology is occluded because so much of the local stratigraphic column, despite the lithotype indicated by formation name, is composed of clastic particles held in a carbonate matrix and carbonate beds containing significant percentages of clastic particles. The relationship probably is further occluded by the non-uniformity in depth and extent of weathering, which influences the development of secondary permeability within each formation.

A water-table contour map of burial ground 6 (fig. 20) indicates that recharge to the regolith is received from areas of higher head underlying the hills to the northwest and from the infiltration of rain that falls upon the site. The principal recharge area within the burial ground is the upland through the north-central part of the site. This includes areas where both the higher activity wastes and low-level wastes have been buried. The hills in the southwest corner and near the southeast border of the site also provide recharge, but probably in amounts subordinate to that through the north-central area.

Bentonitic soil covers have been emplaced over three areas having numerous waste-filled trenches to reduce direct infiltration through the waste. The bentonitic caps likely have little effect on total recharge to the site as infiltration that is not absorbed by the clays or lost by evapotranspiration must move laterally, either as shallow subsurface flow or as overland runoff. It then has potential to infiltrate downward after passing the perimeter of the treated areas.

The general direction of ground-water flow is shown by arrows on figure 20. Again, flow in local areas may be diverted from the directions shown to a direction closer to formation strike by beds resistant to weathering and gradients within subsurface structural features. During winter, a ground-water mound develops below the hill along the southeast boundary, and the flow pattern in this area changes from that shown. The mound dissipates by flow in all directions. That part of the mound facing northwest drains to the two small streams to its north and west. Seasonally high potentials in this area also cause flow from the north-central part of the site to be diverted to these same drainages at that time.

A French drain (fig. 20) installed in late1983 also can be expected to cause local distortions to the flow pattern shown. The drain is about 30 feet deep near its elbow, from which 


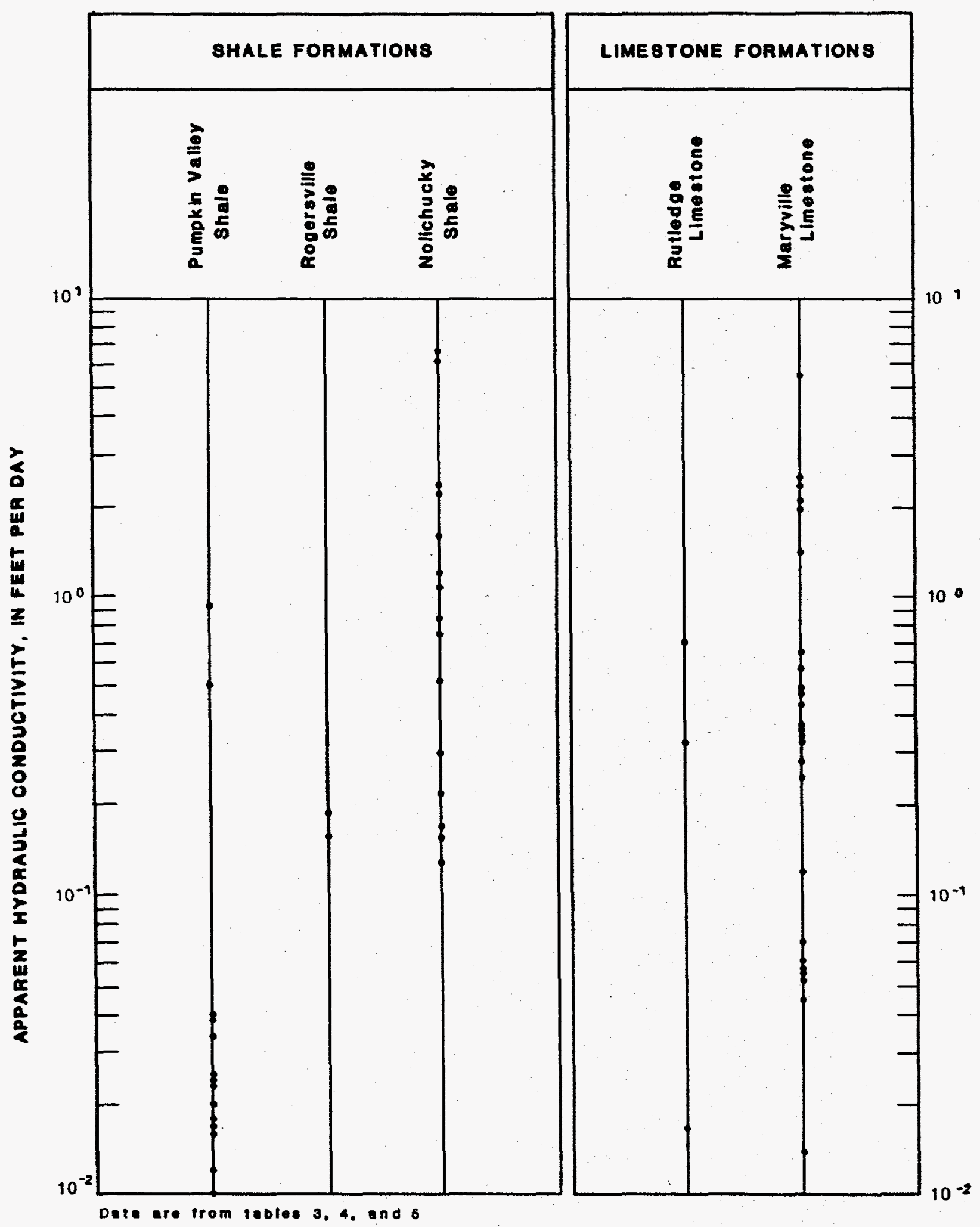

Figure 19.--Logarithmic distribution of apparent hydraulic conductivities by formation. 


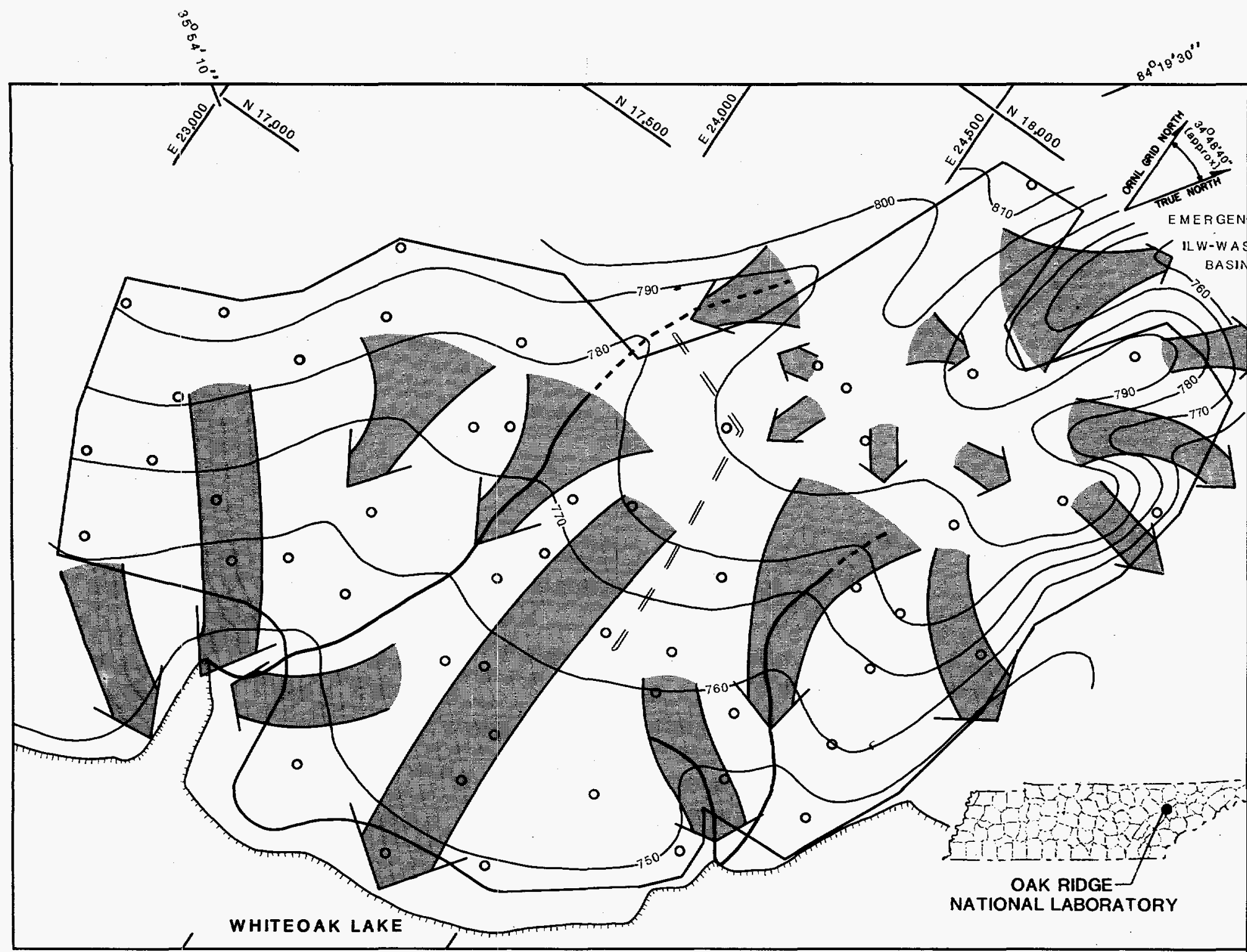

Base from ORNL Engineering Drawing C-10822-EA-006-D

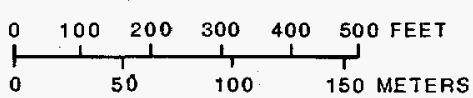

\section{EXPLANATION}

-760- WATER-TABLE CONTOUR--Shows altitude of water table.

Contour in terval 10 feet. Datum is sea level.

O WELL

- DRAINAGE

THITाT WHAK LAKE SHORELINE (1978)

- SITE BOUNDARY

= FRENCH DRAIN-- installed in 1983

GENERAL DIRECTION OF GROUND-WATER FLOW IN REGOLITH

N 18,000 OAK RIDGE NATIONAL LABORATORY GRID COORDINATE

Figure 20.-Water-table contours at burial ground 6 for typical mid-season condition, May 31, 1978, and general direction of ground-water flow. 
point both limbs extend down-gradient at a slight angle to terminate at, and to discharge their fluid upon land surface. Where the drain is below the water table the equipotential lines may shift northerly, and where the unlined section of the drain is above the water table, and at both ends, the equipotential lines may shift southerly as a result of ground-water recharge. Regardless, flow lines adjusted for this influence would still lead to the two small drainages to the west and south of the drain.

It is of interest to note that excavation of the drain revealed unrippable beds at two points on the north limb (Davis and Stansfield, 1984, p. 24-26). These beds probably are limestone, and likely represent local barriers to flow across them. Where the inferred water-table gradient crosses them, the beds will divert flow to a point where they are fractured or sufficiently weathered to permit the passage of water through them. They provide an example of zone 2 of the conceptual model of flow through the regolith.

Discharge from the regolith of this burial ground is to the drainages within the site, the drainage along the northeast boundary, and directly into Whiteoak Lake. Thus, all discharge from the regolith of this disposal site is into the Whiteoak Creek system. The contour pattern indicates that discharge is disseminated along the lengths of the drainages and the lake's shoreline without its being concentrated along any particular reach.

Unlike burial grounds 4 and 5 , trenches at this site do not overflow. This appears to be a result of restricting trench length, depth, and location. However, one seepage into the drain- age has been found west of well 279 (Cerling and Spalding, 1981, p. 79).

Average velocity of flow through much of the site can be estimated by substituting the following values in equation (1):

$$
\begin{aligned}
\mathrm{K}= & 0.45 \mathrm{ft} / \mathrm{d} \text {, representing the geometric } \\
& \text { mean of the hydraulic conductivities } \\
& \text { of wells tested; } \\
\mathrm{n}= & 0.03 \text {, derived from the ground-water } \\
& \text { tracer tests in this burial ground; and }
\end{aligned}
$$
$\mathrm{dh} / \mathrm{dl}=0.055$, the average hydraulic gradient through the central and western sectors of the site.

A velocity of $0.82 \mathrm{ft} /$ day is indicated for midseason.

The slope of the water table below the east end of the site where the higher-activity wastes have been buried is about four times greater than that to the west, which implies greater velocity of flow. The transmissivity of the regolith in this area, though, probably is less because the depth to water is greater, and therefore, the saturated thickness of the material is less. Unfortunately, only two of the four wells ( 368 and 385 ) tested in this area yielded usable data, and the results differ by two orders of magnitude. If a hydraulic conductivity of $1.0 \times 10^{-1} \mathrm{ft} / \mathrm{d}$, which is thought reasonable, can be assumed "average" for the greater depth, a flowvelocity no greater than that of the area to the west results.

The time required for a particle of water to travel along the longest flow path from point of recharge to point of discharge into Whiteoak Lake at the indicated velocity would be 5 to 6 
years. Actual time of travel may be considerably less because of seasonally higher gradients, interception of a more highly permeable pathway, geologic structures that could divert flow to a shorter pathway, and a French drain that could intercept flow and discharge the particle almost immediately. The indicated time of travel from all other points within the burial ground would be less than that calculated because of shorter distances to points of discharge.

\section{HYDROLOGY OF THE BEDROCK}

\section{BACKGROUND AND METHOD OF INVESTIGATION}

From prior studies it had been generally thought that radionuclides dissolved in ground water are unlikely to be transported into the bedrock because of the high sorption and ion exchange potential of the weathered Conasauga Group and the very low permeability of the underlying bedrock. In 1976, as a part of this study, geophysical logs were made of the small number of wells that had been drilled into the bedrock underlying burial grounds 5 and 6 , and of one well in the ILW area during earlier years. Gamma logs revealed anomalous concentrations of garnma activity as much as 100 feet below the top of bedrock; spectral logging identified the activity as cesium-137 in the burial-ground wells and cesium- 137 and cobalt- 60 in the ILW-area well. Both isotopes are associated with nuclear waste, thereby implying subsurface transport of those contaminants through bedrock from point of disposal to the wells. Because of the finding of radionuclides in a medium that hitherto had been thought to be virtually immune to them, the scope of this work was expanded in 1977 to include consideration of ground-water flow and radionuclide transport through the material underlying the regolith. The objective was not to hypothesize and test a different concept of flow than previously conceived, but to build upon it with information useful for further describing flow in the bedrock.

Additional information requirements for the expanded study were the lithology and structure of the rock, the extent of secondary openings in the rock, the transmissivity of the material, the vertical and lateral hydraulic gradients, and the magnitude and extent of present contamination. The hydrologic information was obtained by constructing new wells as piezometers and monitoring potentiometric heads in them, installing packers in five existing wells to obtain supplemental data on head relationships, performing aquifer tests, logging numerous wells in Melton Valley with geophysical instruments, and obtaining radiochemical analyses of water from the piezometers. Much of the geologic information necessary was developed by ORNL scientists under a related program.

\section{RESULTS}

\section{Piezometers}

Five clusters of piezometers were constructed in burial ground 5 between 1977 and 1982. They are referred to as the north, south, east, west, and central clusters; their locations are shown on the well location map of burial 
ground 5, figure 7. The north cluster includes wells 469A, 470, 471, 472; the south cluster, wells $461,462,463$, and 464 ; the east cluster, wells 473 , 474,475 , and 476 ; the west cluster, wells 465,466 , 467 , and 468; and the central cluster, wells 458 , $459,460,439$, and 440 . The depth interval open to each well is given in table 7 (except the regolith wells) and in the appendix.

Potentiometric-head data were collected from wells in the first cluster during two long interruptions in their construction between 1977 and 1979, and after their completion in 1979. Data collection at the other piezometers was initiated upon their completion in late 1982. The periods of record have been interrupted by pumping the wells in 1979 (two wells only), 1983, 1984 , and 1985 to obtain water samples for chemical analyses. Record collection was resumed in most of the wells before the water surfaces had reached their static level, but because the period of recovery at a few wells is of several months duration, the record of meaningful head relationships at those wells contains large hiatuses. At this time (1985) a complete data set for the entire suite of piezometers and water-table wells is not available for any one date. Consequently, altitudes of the static, potentiometric surfaces at a few piezometers as noted have been estimated on the basis of other record and relationships in order to complete the relationship within the cluster, to relate clusters, and to develop the conceptual model of flow described subsequently.

At the north cluster (fig. 21), a difference in heads of 7 to 9 feet drives water downward from water-table depth to the 100 -foot level. A small difference of less than 1 foot exists between the 100- and 150-foot levels. The vertical component of flow in this interval is downward for several months of the year, but may reverse during the spring months owing to the deeper zone's slow recovery from its seasonal decline in potential. With such a small difference in heads, water in this interval probably has a larger component of lateral flow than vertical flow. A more substantial head difference of 4 to 6 feet exists between the 150-and 200-foot level, giving water between these depths a downward component of flow. The data indicate that the shallow and deeper rock at this site are in ground-water recharge zones; the rock at intermediate depth (100 to 150 feet) probably is in a divide between recharge and discharge zones.

At the south cluster (fig. 22) the vertical component of ground-water flow is upward relative to the water table, and is evidenced by piezometers that were flowing wells before their casings were extended. The ranges in difference in the potentiometric heads between the water table and the 100-, 150-, and 200-foot zones are about 4 to $5^{1} / 2$ feet, 6 to 8 feet, and $4^{1 / 2}$ to 9 feet, respectively. The higher heads with increasing depth provide a driving force upward to horizons having lower head, indicating that this cluster is in a ground-water discharge area. An exception to this relationship exists for a few months during early winter when the potentiometric head in the 150 -foot zone recovers from its seasonal decline before that of the 200 -foot zone, causing the 150 foot zone temporarily to have a higher potentiometric pressure than that of the underlying zone. During these months pressure in the 150foot zone precludes an upward component of water movement from the lower strata in this 


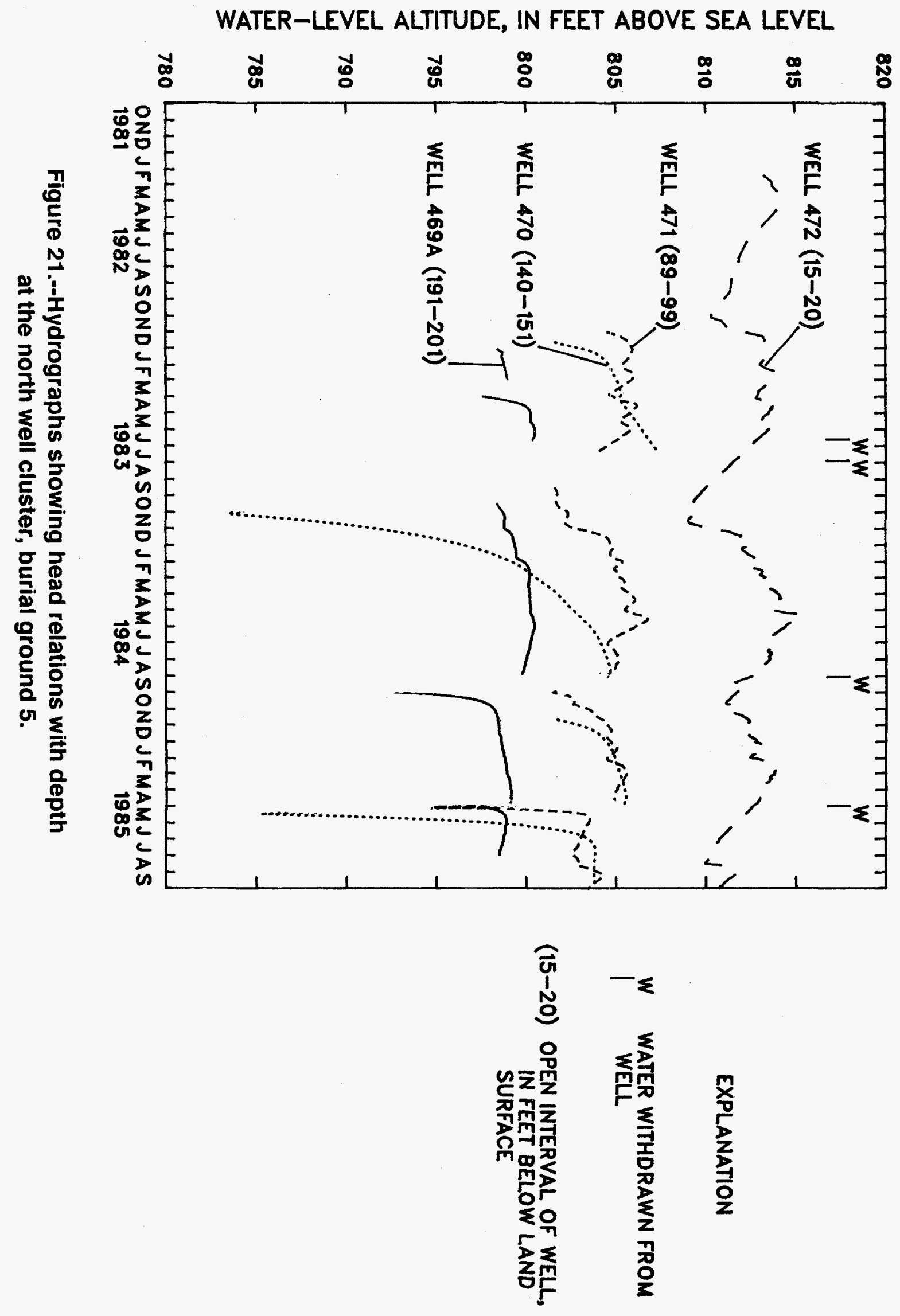




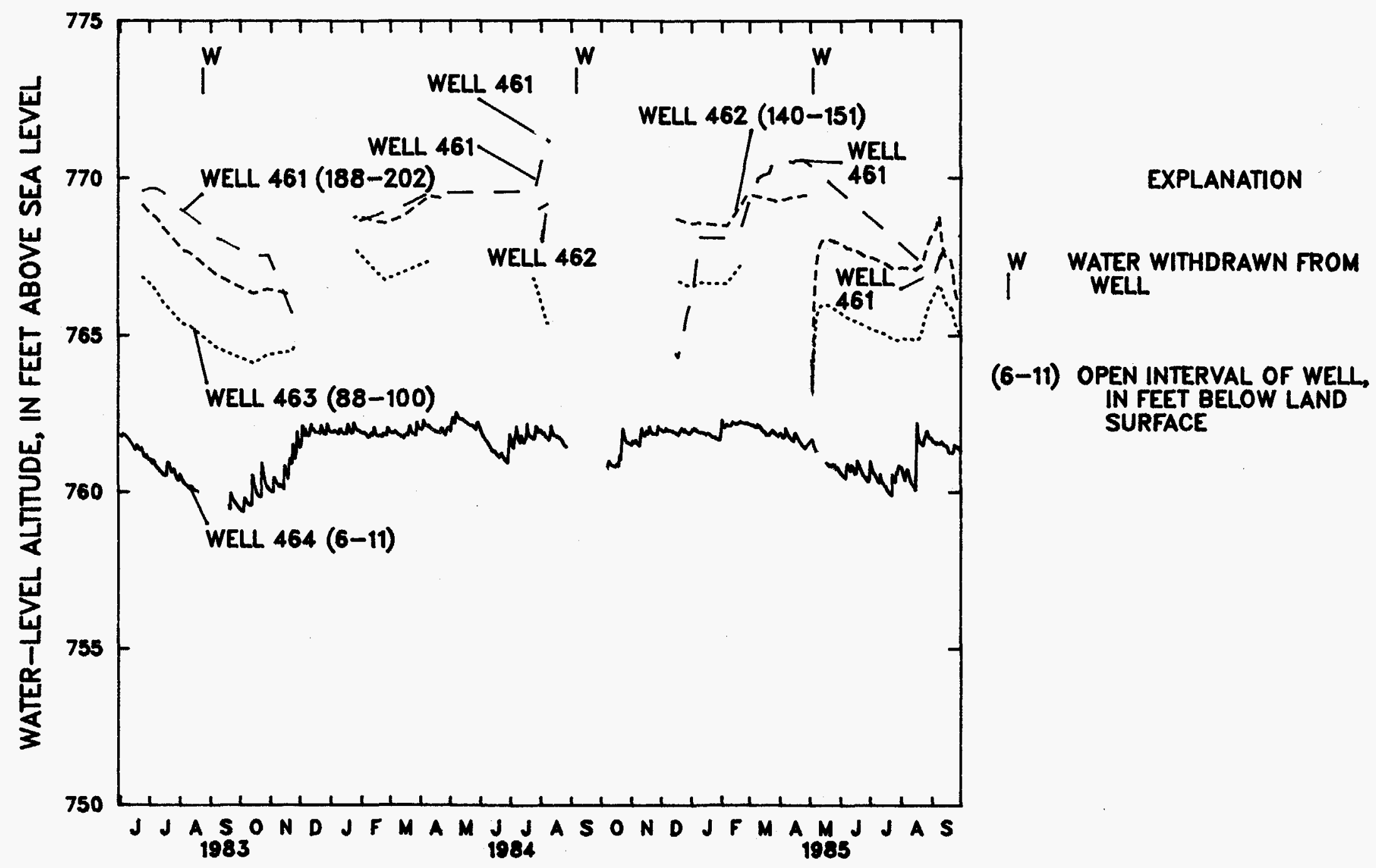

Figure 22.--Hydrographs showing head relations with depth at the south well cluster, burial ground 5. 
area, even though the head relationship between the water table and the 200-foot zone has not changed.

The potentiometric-head relationships of the water-table well and the piezometers of the east cluster (fig. 23) indicate that this site also is in a ground-water discharge area. Differences in heads between the water table and the 100- and 150 -foot piezometers range from about $1 / 2$ to 4 feet and $3 \frac{1}{2}$ to 7 feet, respectively. The usable record of well 473 (the 200-foot piezometer) is short. From March to July 1983 the static water level in this well stood about 1 to 2 feet higher than that of well 474,3 to 6 feet higher than that of well 475 , and 3 to 8 feet higher than that of well 476 . A higher potential of this well relative to the other three also is indicated by the record of mid-summer 1984 before the well was pumped. An upward component of flow from all four horizons thus is characteristic of this site.

At the west cluster, the 100 -foot piezometer has a potentiometric head that is 2 to 6 feet lower than the water-table well and $1 \frac{1}{2} 2$ to 3 feet lower than the 150 -foot piezometer (fig. 24). Several more months must pass before the water surface in the 200-foot piezometer reaches its static level. In order to complete the characterization of this cluster, it is estimated that the altitude of the static potentiometric surface in the 200-foot piezometer stands 2 to 3 feet higher than that of the 150-foot piezometer. This estimate is based on the general similarity between the topographic position of this site with that of the south and east clusters, and the short distance between the site and the principal stream of the area. Thus, the vertical component of flow at this site is downward toward the 100-foot zone from the water table, and inferred to be upward toward the 100 -foot zone from the 200 -foot zone. The shallow rock is in a recharge area, whereas the deeper rock is in a discharge area.

The central cluster is located on a slope. Because of a 6- to 7-foot difference in watertable altitudes in the two shallow wells (wells 439 and 440), it is necessary to calculate water-table altitudes at a single point for the period of interest. For this purpose, altitudes have been computed for a point midway between the two wells. This point lies a short distance north of well 460 , the 100-foot piezometer. The hydrograph of the water-table well shown on figure 25 thus is not that of an actual well, but a synthesized hydrograph based on the data of wells 439 and 440 for a well if constructed at this point. If the water table at points represented by the 150 - and 200foot piezometers (wells 459 and 458, respectively) is compared to the potentiometric surface in those same wells, the water table will stand somewhat higher, and the differences between the water table and potentiometric surface will be correspondingly greater than that shown in figure 25.

The highest potentiometric head is found in the 140-foot piezometer and the second highest in the water-table well, indicating a downward component of flow from the regolith to the 100-foot zone and an upward component of flow from the 140 -foot zone to the 100 -foot zone. The lowest head in the group is found in the 200-foot piezometer, indicating another downward component of flow between 140 and 200 feet. It also may be noted that during the interruption in construction during 1977-78, the potentiometric head in well 458 , open at that time from 100 to 


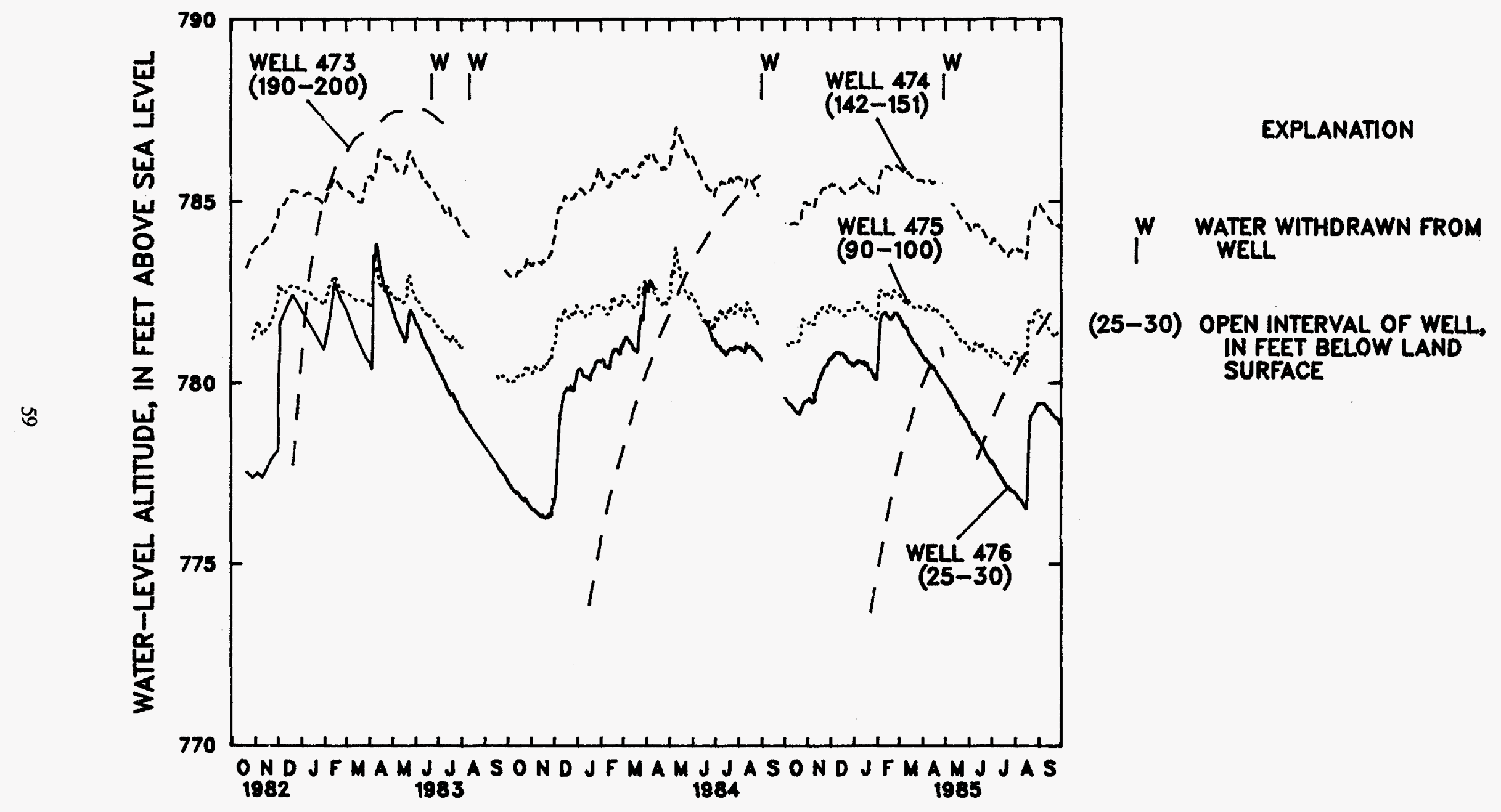

Figure 23.--Hydrographs showing head relations with depth at the east well cluster, burial ground 5 . 

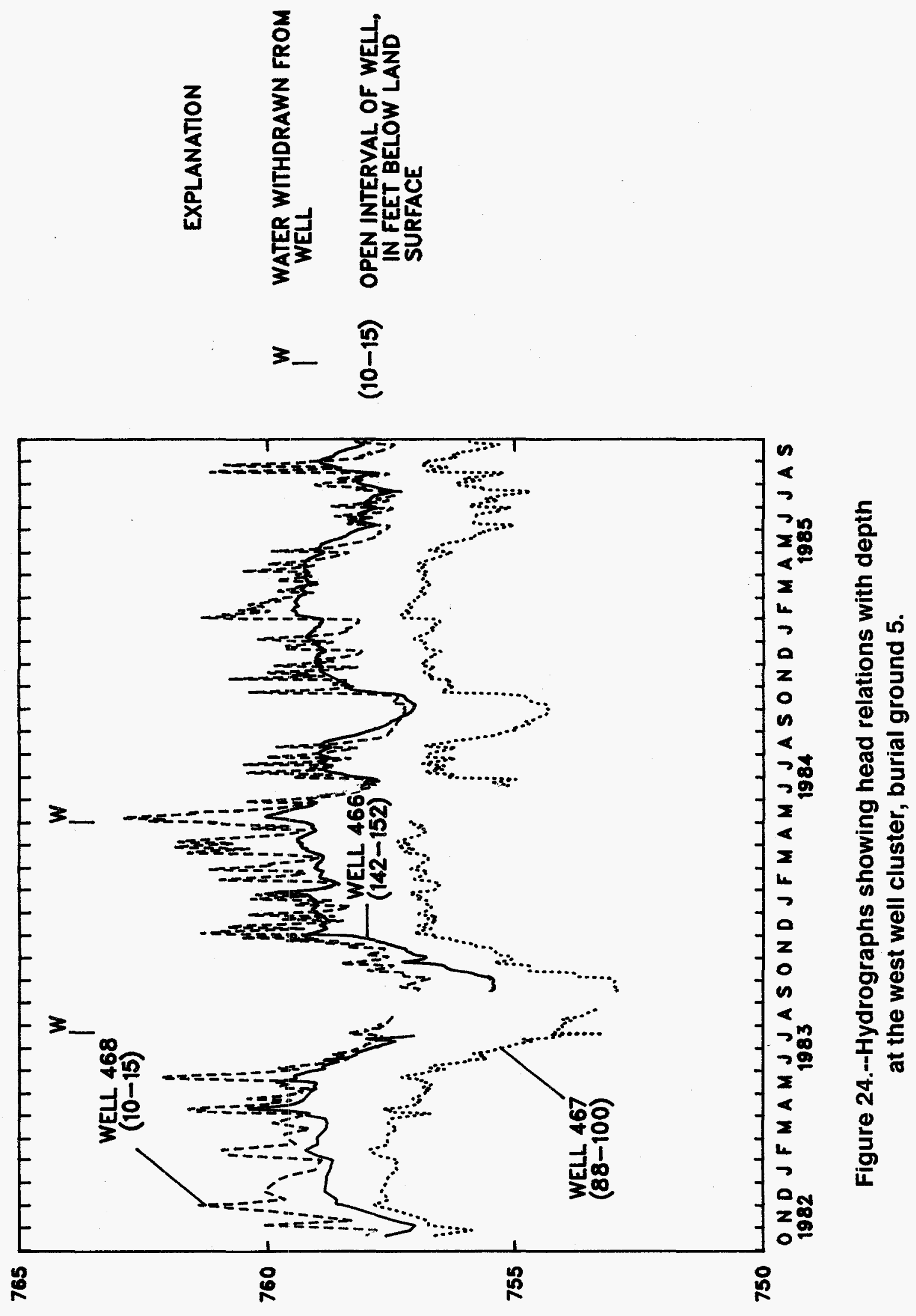

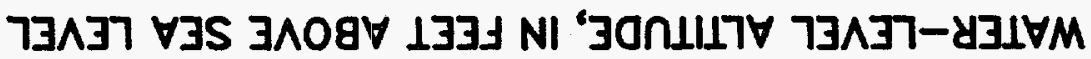



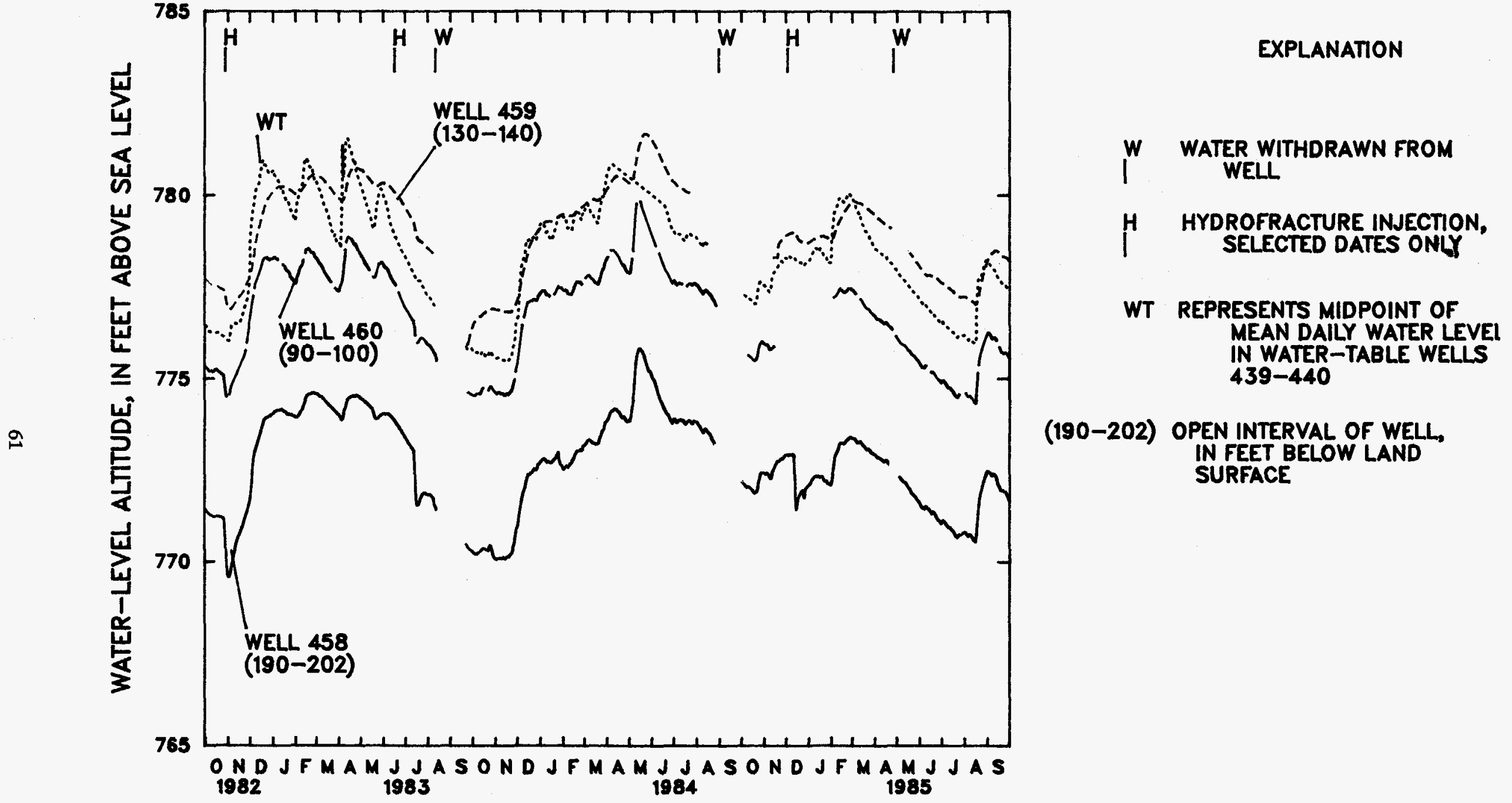

Figure 25.--Hydrographs showing head relations with depth at the central well cluster, burial ground 5. 
150 feet, indicated an upward component of flow relative to well 460 , open from 44 to 100 feet. It appears that at this site the rock at shallow depth (above 100 feet) is in a ground-water recharge zone; the rock at intermediate depth (100 to 150 feet) is in a discharge zone; and the rock at greater depth is in another recharge zone.

Examination of the potentiometric data for these clusters shows two stresses superimposed upon the normal seasonal rise and decline of the water surface in some of the wells. The stresses are considered here because of their potential to alter the basic head relationship between piezometers. The first, of natural origin, is earth tides which result in a diurnal rise and decline of water levels. The patterns of water-level change, time of peaks, and amplitude of the wave from piezometer to piezometer are variable. With a maximum amplitude of about 0.15 foot in those records where this phenomenon is identifiable, the effects of earth tides are of insufficient magnitude to reverse the head relationships at any cluster. The other stress is the hydraulic fracturing of bedrock at a nearby waste-disposal facility (fig. 1, site HF-2). The rock beneath that facility is fractured at depths of about 1000 to 700 feet to enable the injection of liquid radioactive-waste carried in a grout slurry. Pressure created within the rock by fracturing and injecting the slurry has caused the water levels in some of the piezometers to respond, although the responses have been variable.

The effect of recent injections has been to depress water levels in piezometers in the central cluster, and to raise water levels in some of the piezometers of the west, north, and east clusters. Inasmuch as the south cluster was not instru- mented until 1985 the effects in that area are not yet determinable. The largest impact recorded was at well 458 (the 200-foot piezometer) in the central cluster where a 1.5 -foot decline resulted from fracturing on July 12, 1983, and pressure of slurry injection 1 to 2 days later (fig. 25). The water levels in wells 459 and 460 (the 150- and 100 -foot piezometers, respectively) each declined about 0.5 foot as a result. The pattern of response was for declining water levels over a period of several days, followed in well 458 by a partial recovery for a shorter period of time. Smaller changes that were more quickly assimilated were associated with the other clusters. Although water-level records for all clusters during injection events are incomplete, it appears that the direction of change (that is, either up or down) is consistent for each bedrock well within a cluster. Water levels in the shallow wells that extend only short distances below the water table are not affected by injections. It does not appear that the magnitude of water-level change in the central cluster, the site most impacted by this stress, has been sufficient to alter the basic potentiometric-head relationships between the three piezometers within the cluster, or with those of the other clusters, by the pressures developed.

\section{$\underline{\text { Packers }}$}

To supplement information provided by the piezometers, single packers were installed in each of the five wells (wells 174 through 178) in burial ground 5 that had been drilled into bedrock during the pre-site evaluation of 19581960. In three of these wells the packers were set at various depths in bedrock for a few days in 
order to obtain head relationships above and below the packer. Later, the packers were set for a period of 8 months or longer in the five wells at the first horizon below the bottom of the casing at which a hydraulic seal could be developed. The principal purpose of setting packers at these horizons was to provide data about the head relations near the regolith-bedrock interface.

At well 174 (fig. 26) the top of the packer was set in August 1981 at a depth of about 60 feet, slightly above the existing water surface in the well. In the months that followed, the water surface gradually rose above the packer and finally stabilized at depths ranging from about 38 to 45 feet. The potentiometric surface of the zone below the packer fluctuated within a range of about 53 to 60 feet. A head loss of about 15 to 20 feet between the two zones indicates that water in the regolith and upper bedrock near this well has a substantial downward component of flow. Packer settings at depths of 95,107 and 115 feet for a few days at each setting also indicated a downward component of flow relative to the intervals above and below the packer. The duration of each setting, however, was inadequate to determine the magnitude of the difference in static potentials between the two intervals.

The comparatively long period of time (about 4 months) taken for the upper water level to stabilize when the packer was set at 60 -feet depth suggests that this well, by vertical flow within the well bore, drained the regolith over an area of large radius surrounding it, much the same as a well that is continually pumped causes a cone of depression to develop in the area surrounding it. To investigate this possibility, the water-level in well 445 , about 200 feet to the south of well 174 and the closest well to it, was monitored from August 1981 to August 1982. No significant change in water level patterns from that of $1977-79$ was found to occur in this well. If local drainage of the regolith did occur through well 174, the area drained did not extend as far south as well 445 .

At well 175 (fig. 27) the top of the packer was set at a depth of about 43 feet. The potentiometric surface of the zone below the packer (45 to 148 feet) rose about 2 feet above that of the zone above the packer, indicating a slight upward component of flow from the bedrock into the regolith. The relationship reversed for short periods of time following the more substantial recharge events. Previous packer settings for short periods of time showed that at depths of 108 and 122 feet, very little difference (about one-half foot) existed in the potentiometric surfaces above and below the packer. At 130 feet, however, the potentiometric surface for the zone above the packer stood about $2-1 / 2$ feet higher than that for the lower 20 feet of the well, indicating a downward component of flow at that depth.

Packers were set in wells 176,177 , and 178 at depths of 53,61, and 42 feet, respectively. Head relationships between the zones above and below the packer indicated downward components of flow at each well, similar to that of well 174 , although of smaller magnitude (figs. 28, 29, and 30). In well 176, additional settings at depths of 95 feet, 110 feet, and 123 feet also indicated downward components of flow at those depths, relative to the zones above and below the packer.

These data show that water in the lower regolith/upper bedrock at each well except well 


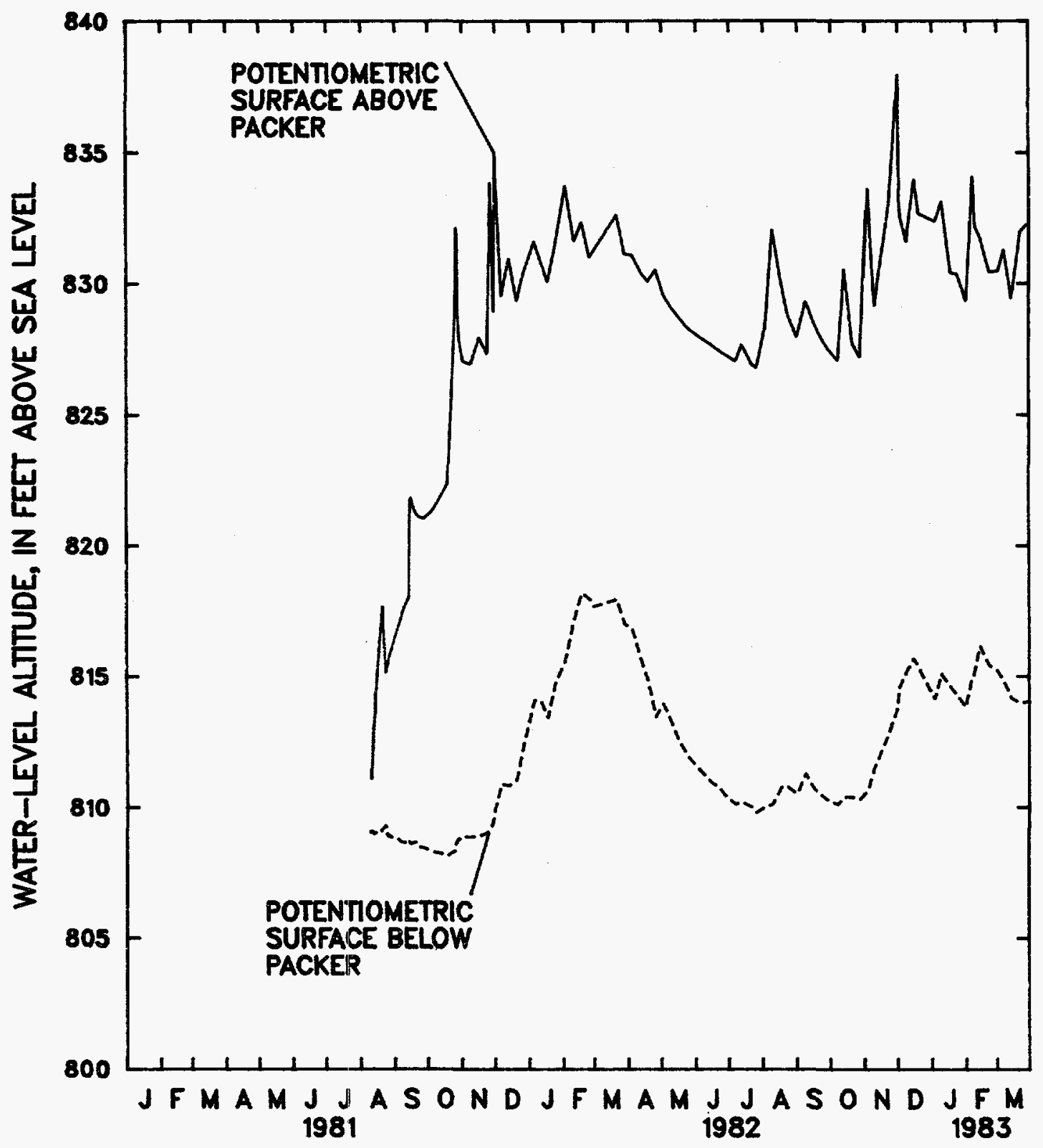

Figure 26.--Hydrographs showing vertical gradient at well 174 with packer set at 60- to 64-foot depth. 


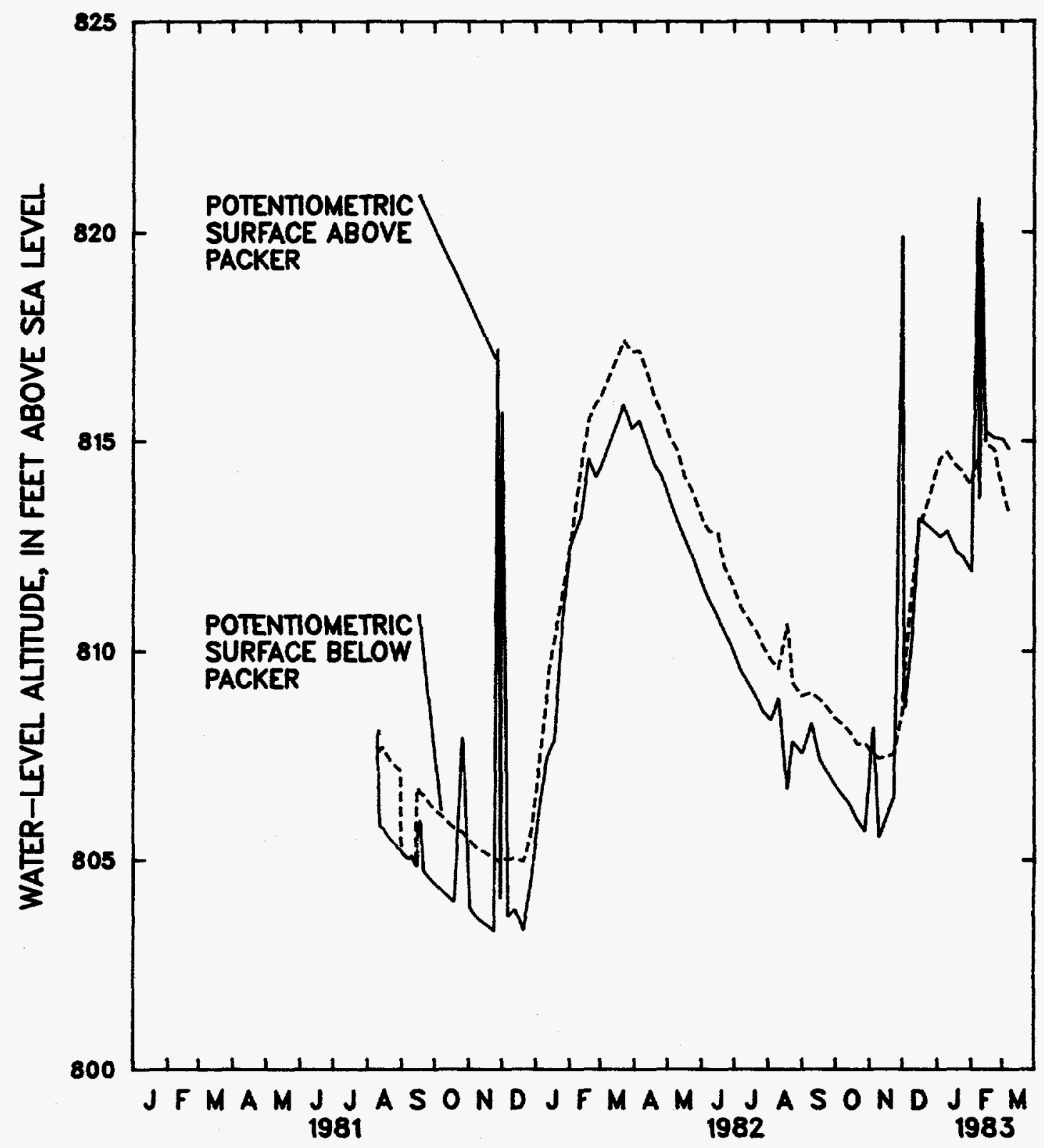

Figure 27.--Hydrographs showing vertical gradient at well 175 with packer set at 43- to 45-foot depth. 


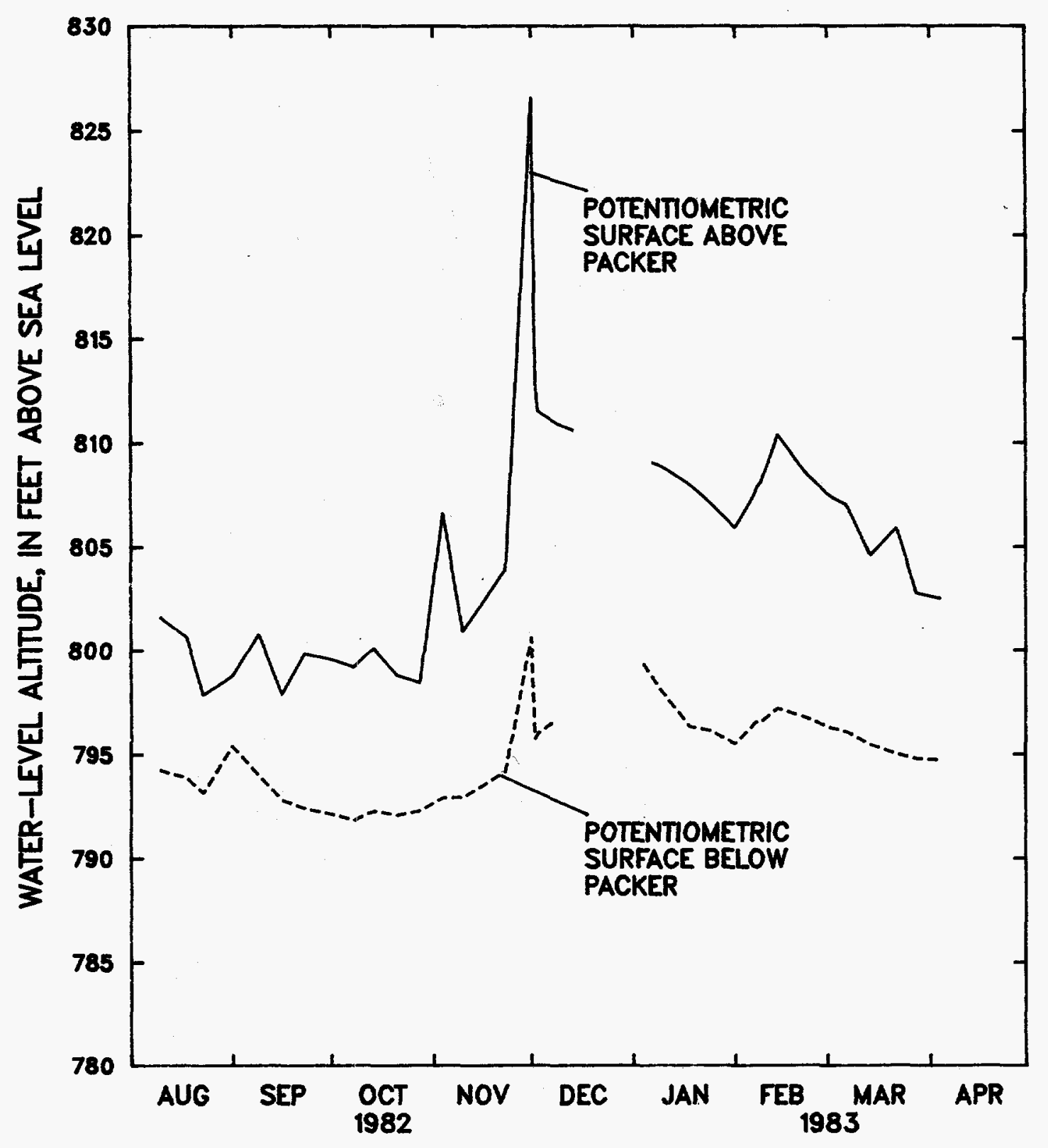

Figure 28.--Hydrographs showing vertical gradient at well 176 with packer set at 52- to 54-foot depth. 


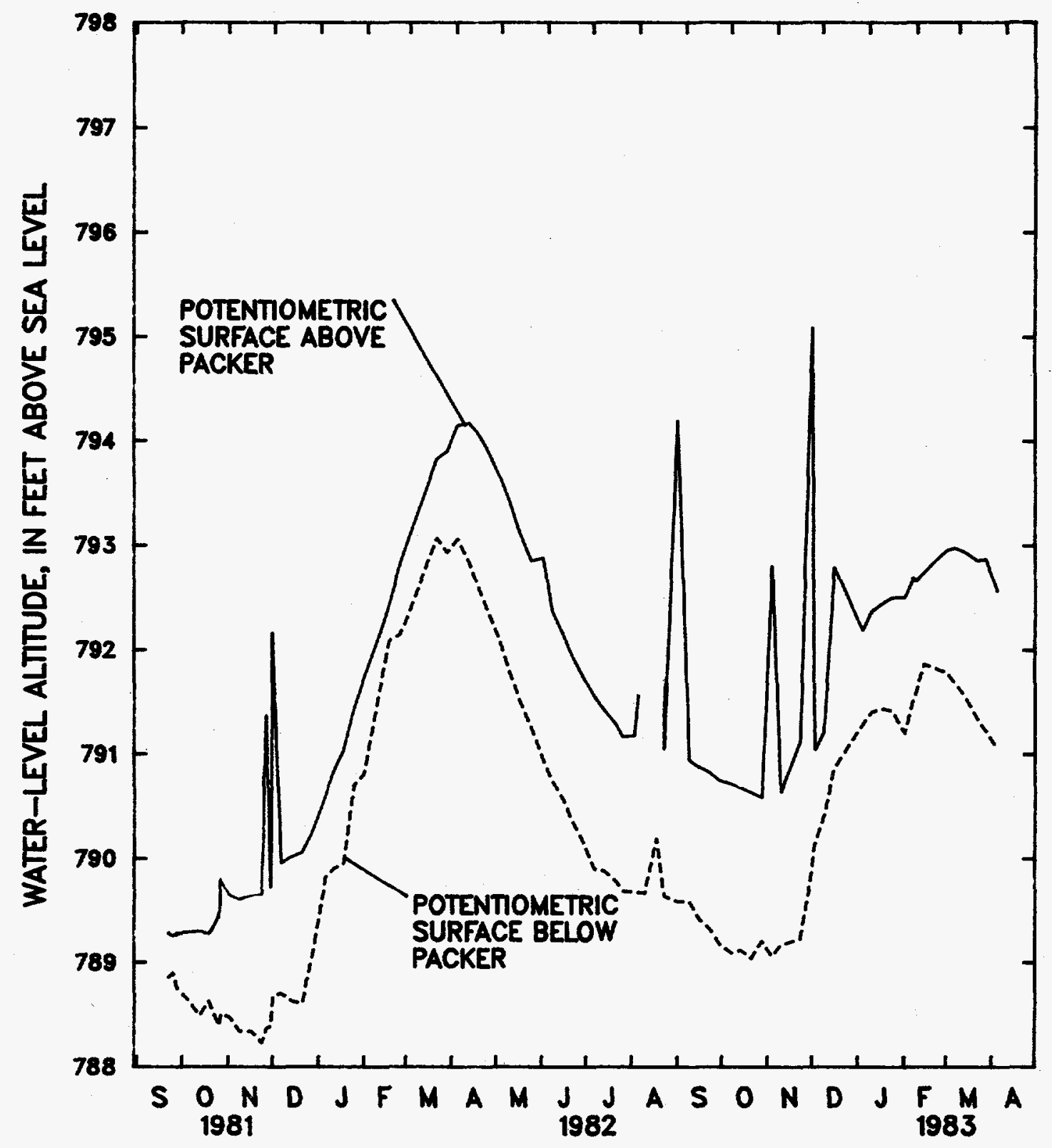

Figure 29.--Hydrographs showing vertical gradient at well 177 with packer set at 61- to 64-foot depth. 


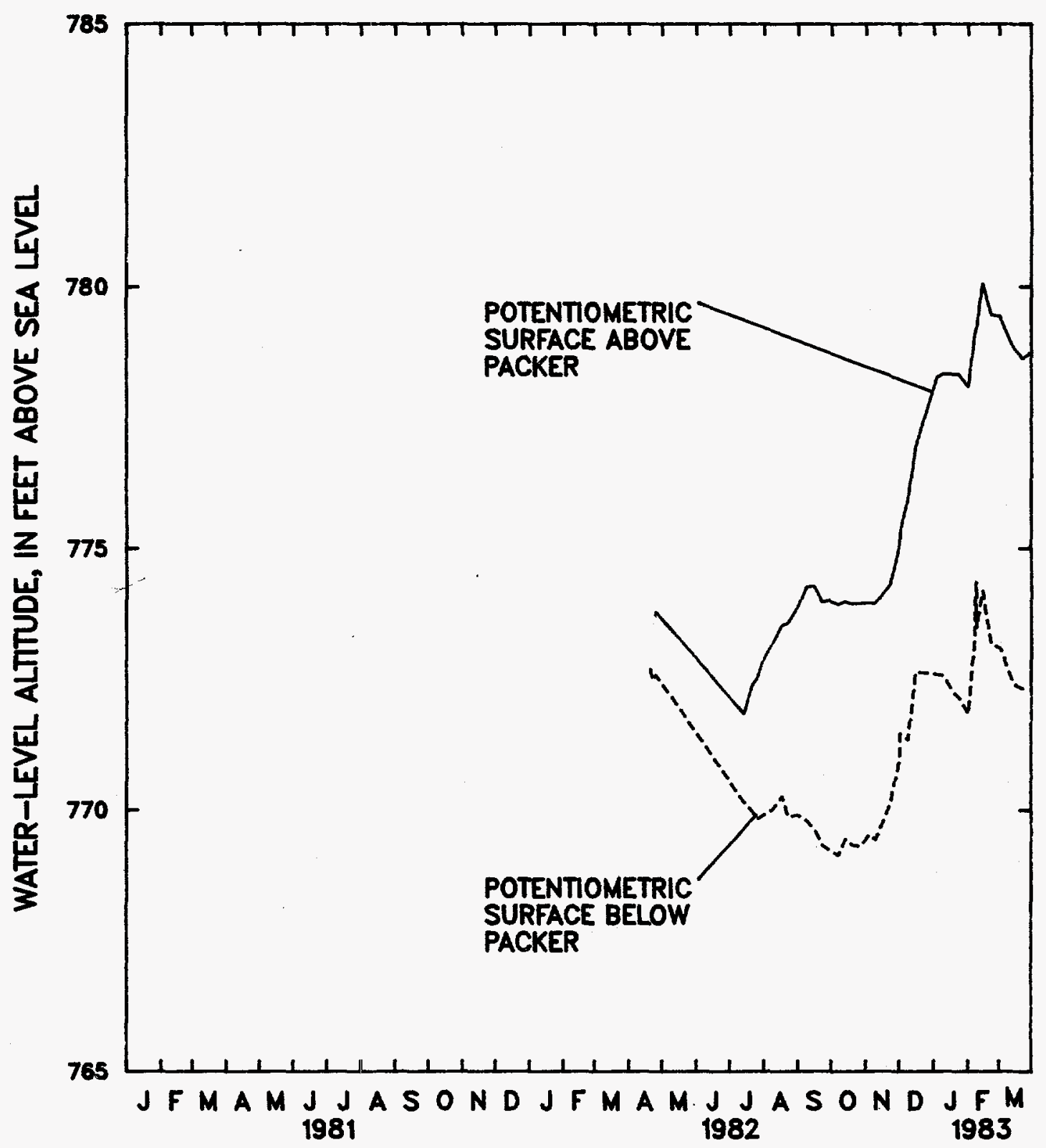

Figure 30.--Hydrographs showing vertical gradient at well 178 with packer set at 42- to 44-foot depth. 
175 has a downward component of flow relative to deeper bedrock, that is, these wells are located in ground-water recharge areas. Well 175 , with a small upward component of flow, appears to be a local anomaly, possibly related to a structural feature at 70 feet depth or suspected solution channels at 87 and 101 feet depth, shown in the televiewer log.

With packers set near the top of bedrock in each well, the response of water levels in the two zones to the more substantial recharge events was similar, that is, both water levels rose. Response of the zone below the packer, as expected, usually was the lesser of the two. The similarity in response supports the thesis that the regolith and bedrock system are hydraulically connected.

\section{Aquifer Tests}

During the interruption in construction of the first piezometer cluster from 1978-79, slug tests were made of the open intervals then in each well (wells 458,459, and 460) and of the lowermost zone at which a pneumatic packer could be sealed. Results of these tests are given in table 6. Later, pumping tests of 24 hours duration each were performed in wells 458 and 460 to obtain more accurate coefficients of transmissivity and hydraulic conductivity than was then thought to be obtainable from slug tests, and to determine if the water levels in the nearby wells would be drawn down which would indicate hydraulic continuity of secondary openings through the bedrock. At the time of the test, well 458 was open from about 150 to 203 feet, and well 460 , from 44 to 100 feet. The pumping rates, determined by analysis of the slug test data, were $0.7 \mathrm{gal} / \mathrm{min}$ and $0.385 \mathrm{gal} / \mathrm{min}$, respectively. Analyses of the pumping test data were by the method of Papadopulos and Cooper (1967) for a well in which the well's storage capacity must be considered. The results are included in table 6 .

The values given, like those derived from the slug tests, should be regarded as approximations of actual $T, S$, and $K$ coefficients because the geologic conditions do not conform to the analytical assumptions of a homogeneous and isotropic medium. They are indicative, however, that the coefficients of transmissivity and hydraulic conductivity of the bedrock are quite low, and by comparison, less than the corresponding values for the regolith. The $\mathrm{S}$ coefficients have greater potential than those of $T$ and $\mathrm{K}$ to be in error because, as noted previously, the method for slug-test analyses is relatively insensitive to changes in $\mathrm{S}$, and 24-hour pumping tests at low yields are of inadequate time to define this coefficient with accuracy.

It was found that both tests influenced the water levels in the other two piezometers then under construction and in some of the other nearby shallow wells, thereby demonstrating that the secondary openings in the bedrock do have hydraulic continuity in the vertical direction.

The analyses for apparent $T$ and apparent $\mathrm{K}$ of the two pumping tests approximated those of the two slug tests of the same well interval. The general similarity of values indicated that reasonable coefficients for these parameters could be obtained by slug tests only, which require less time, equipment, and manpower to perform. 
Table 6.--Aquifer-test data of bedrock wells in the central cluster

Slug tests:

Pumping tests:

Well 458

$150-203$ foot interval

190-203 foot interval

150-203 foot interval

Apparent T

$1.6 \mathrm{ft}^{2} / \mathrm{d}$

$0.3 \mathrm{ft}^{2} / \mathrm{d}$

Apparent S

$1.5 \times 10^{-8}$

$1.6 \times 10^{-12}$

Apparent K

$0.03 \mathrm{ft} / \mathrm{d}$

$0.03 \mathrm{ft} / \mathrm{d}$

$1.6 \mathrm{ft}^{2} / \mathrm{d}$

$1.6 \times 10^{-5}$

$0.03 \mathrm{ft} / \mathrm{d}$

Well 459

100-150 foot interval

Apparent $T$

$1.1 \times 10^{-2} \mathrm{ft}^{2} / \mathrm{d} \quad 1.1 \mathrm{ft}^{2} / \mathrm{d}$

136-150 foot interval *

Apparent S

$1.6 \times 10^{-4}$

$1.6 \times 10-5$

Apparent K

$2.2 \times 10^{-4} \mathrm{ft} / \mathrm{d}$

$8.1 \times 10^{-2} \mathrm{ft} / \mathrm{d}$

No pumping test performed of this well

*Results are questionable because of suspected leakage around the packer.

Well 460

44-100 foot interval

Apparent T

Apparent S

Apparent K
$1.4 \mathrm{tt}^{2} / \mathrm{d}$

$1.6 \times 10^{-4}$

$0.02 \mathrm{ft} / \mathrm{d}$
84-100 foot interval

$0.2 \mathrm{ft}^{2} / \mathrm{d}$

$1.4 \times 10^{-4}$

$0.015 \mathrm{ft} / \mathrm{d}$
44-100 foot interval

$1.6 \mathrm{ft}^{2} / \mathrm{d}$

$7.5 \times 10^{-4}$

$0.03 \mathrm{ft} / \mathrm{d}$
During construction of the piezometers 2 to 3 years later, slug tests were performed in the 50-foot interval before installation of the final string of casing. The final 10-foot interval left open to the aquifer was tested after construction had finished. The apparent hydraulic conductivity values of the two intervals tested in each well are given in table 7. Data of the piezometers in the central cluster and also of the water-table wells in each cluster are included in this compilation to facilitate a comparison of values by location and depth.
The range in hydraulic conductivity spans nearly four orders of magnitude and might even be greater if tests were performed in the wells that recharge very slowly. The range reflects the degree of heterogeneity that exists in the aquifer. Lateral heterogeneity is shown by reading the values horizontally across the table, and is more prominent in the 10-foot intervals than in the 50foot intervals. Lateral heterogeneity also has been shown by pumping tests conducted during earlier investigations of the Conasauga Group, where the water levels of those wells oriented 
Table 7.--Apparent hydraulic conductivities of wells in piezometer arrays

\begin{tabular}{lccccc}
\hline \multirow{2}{*}{ Depth interval } & \multicolumn{5}{c}{ Apparent hydraulic conductivities (ft/d) by cluster } \\
\cline { 2 - 6 } North & South & East & West & Central \\
\hline Water table ${ }^{(1)}$ & $3.3 \times 10^{-1}$ & $7.6 \times 10^{-1}$ & $*$ & $4.9 \times 10^{-1}$ & $5.8 \times 10^{-1}$ (Well 439) \\
& & & & & $5.3 \times 10^{-2}$ (Well 440) \\
$50-100$ & $1.8 \times 10^{-2}$ & $2.2 \times 10^{-2}$ & $8.0 \times 10^{-2}$ & $*$ & $2.5 \times 10^{-2}(2)$ \\
$100-150$ & $1.1 \times 10^{-3}$ & $7.0 \times 10^{-3}$ & $1.0 \times 10^{-2}$ & $1.4 \times 10^{-1}$ & $2.2 \times 10^{-4}$ \\
$150-200$ & $1.3 \times 10^{-3}$ & $1.0 \times 10^{-3}$ & $8.0 \times 10^{-3}$ & $1.0 \times 10^{-2}$ & $3.0 \times 10^{-2}(2)$ \\
Water table & $3.3 \times 10^{-1}$ & $7.6 \times 10^{-1}$ & $*$ & $4.9 \times 10^{-1}$ & $5.8 \times 10^{-1}$ (Well 439) \\
& & & & & $5.3 \times 10^{-2}$ (Well 440) \\
$90-100$ & $4.3 \times 10^{-3}$ & $*$ & $1.0 \times 10^{-1}$ & $1.0 \times 10^{-1}$ & $1.5 \times 10^{-2}(3)$ \\
$140-150$ & $1.5 \times 10^{-4}$ & $1.3 \times 10^{-2}$ & $2.3 \times 10^{-2}$ & $1.9 \times 10^{-1}$ & $8.1 \times 10^{-2}(3,4)$ \\
$190-200$ & $3.5 \times 10^{-4}$ & $2.9 \times 10^{-4}$ & $* *$ & $* *$ & $3.2 \times 10^{-2}(3)$ \\
\hline
\end{tabular}

*Data do not fit type curve.

**Slug test not performed due to very slow water-level recovery after pumping well.

(1) Depth interval of water-table well varies from cluster to cluster. Refer to Appendix A for open interval of wells $472,464,476,468,439$, and 440 , respectively.

(2) Depth interval is 44 to 100 feet in well 460 and 150 to 203 feet in well 458 (Central cluster).

(3)Depth interval is 84 to 100 feet in well 460, 136 to 150 feet in well 459, and 190 to 203 feet in well 458 (Central cluster).

${ }^{(4)}$ Value is questionable because of suspected leakage around packer.

along strike were drawn down more than those at an equivalent distance across strike from the pumped well (deLaguna and others, 1958, p. 106107; unpublished manuscript in files of USGS). Vertical heterogeneity is shown by reading the table vertically, either by the 50 -foot intervals or by the 10 -foot intervals. The overall trend in data demonstrates that hydraulic conductivity decreases as depth increases, although reversals to this relationship may occur at any point in the stratigraphic column. Several reversals are shown by comparing the value of the 10 -foot interval to that of the larger 50-foot interval of which it is a part. Of the 11 comparisons that can 
be macle, in 5 wells the hydraulic conductivity of the bottom 10 feet is greater than that of the 50foot interval. Decreasing hydraulic conductivity with increasing depth was also demonstrated indirectly during the 1950's by measuring the rate of water acceptance in bedrock wells in the ILW area and and in burial ground 5. In these tests measurements were made in 20 -foot depth increments and similar occasional reversals to the overall trend were found (deLaguna and others, 1958, p. 107; Cowser and others, 1961, p. 15). The relationship of decreasing hydraulic conductivity with increasing depth is significant to bedrock recharge and discharge.

Values for the 190- to 200-foot interval, with the exception of that for the central cluster, are quite small. The fact that water does recharge wells at this depth, however, indicates that the lower boundary of the aquifer occurs at some greater depth. The variability in recharge rates and $K$ values of that interval implies that the depth to that boundary is variable or, in other words, that boundary is a surface of irregular shape.

\section{Geophysical Logging}

Geophysical logs were made intermittenly between 1976 and 1983. The logs include caliper, gamma, gamma-gamma, neutron, acoustic velocity, temperature, televiewer, single-point resistivity, and spectral, but not all of these logs were made of all of the wells. Generally, the logs found most useful to this investigation were the caliper, gamma, neutron, televiewer, and spectral.
Two important applications of logging for investigating ground-water flow in Melton Valley were in establishing the existence and prevalence of secondary features that permit flow through the bedrock, and in identifying certain radionuclides that have been transported by water into bedrock.

The initial logging of the five bedrock wells in burial ground 5 showed occasional zones suggestive of secondary openings in each of the bores. They were also found in nearly all of the piezometers. Logging of the few existing bedrock wells in burial ground 6 also showed their presence there. Additional logging of wells near ILW pits 2,3, and 4 and of some of the wells used in proving the hydrofracture method of waste-disposal also revealed similar features. Visible secondary openings shown in logs are not numerous in any one well bore, but they are prevalent throughout the Melton Valley area. The more common type opening is an enlargement of the well bore indicative of rock weakened by fracturing, folding, or faulting, and easily torn loose as the drill intercepts that stratum. These zones range from a few inches to as much as a few feet in thickness. Some, but probably not all, represent pathways through which water flows. Small partings and fractures that permit the flow of water also are present, but the logs lack sensitivity to show their detail. The presence of these smaller openings, however, is revealed by completion of some of the piezometers in what the caliper and televiewer logs suggest is "solid rock". That these zones have secondary permeability is evidenced by the response of water levels to slug tests and the normal rise and recession of the water surface within the completed well. The less common type of 
opening is a solution channel in the limestone. The largest solution cavities found by logging of these wells probably do not exceed one-half foot in height; most are smaller.

The most frequent location of secondary openings, whether due to fractures or other features of structural origin or to the development of solution channels, is within the upper 100 feet of well bore, but they also occur at substantial depths. For example, the caliper log of well 521, cored in the Rutledge Limestone to a depth of 100 feet, shows increases in borehole diameter characteristic of solution openings at $39.5,40.4$, $49.8,51.0$ and 67.2 feet. The bottom 17 feet could not be logged, owing to material that had sloughed in, but might also have intercepted additional openings. The caliper log of well 400-S, cored about 1000 feet southeast of burial ground 5 to a depth of 1020 feet, shows similar features at depths of 53 feet, in the Nolichucky Shale, and, 281, 444, and 893 feet, in the Maryville Limestone.

One of the more significant findings from the logs of the older wells is the existence of an integrated solution channel network near ILW pits 2 and 4 . The caliper and televiewer logs show that wells 100,101 , and 118 (fig. 9), located in the Maryville Limestone within 200 feet of each other, intercepted solution cavities in the bedrock; the gamma logs of these wells show some of the highest counting rates of wells logged at ORNL. It appears that this network provided an avenue through the bedrock for a disproportionately large amount of fluid flow from these liquid-waste disposal facilities. The presence of an integrated cavity system such as this is not predictable from surficial features, and can only be established by logging wells that intercept these features by chance. Although a similar system was not found in any of the wells of burial grounds 5 or 6 , the potential for its presence there exists by virtue of these sites being underlain by beds of the same formation.

The results of spectral logging of wells in burial grounds 5 and 6 are given in table 8 . In these two areas cesium- 137 was the only manmade radioisotope found in the wells. This radionuclide was found behind the casing in the regolith, near the regolith/bedrock contact, and at or near the bottom of the deeper wells in bedrock.

The initial finding of cesium-137 in well 176 (burial ground 5) at a substantial depth below the top of bedrock caused concern that this radionuclide is being transported through the rock itself. More recent work suggests, although does not provide proof, that the radionuclide is transported sorbed to very-fine grained particulate matter through secondary openings in the regolith or upper bedrock. Its most likely point of entry into the bedrock wells is immediately below the casing, which typically terminates at the top of bedrock.

In view of what then appeared to be a significant possibility of encountering radionuclides in bedrock, the piezometers at burial ground 5 were constructed in stages to limit potential for the down-hole transfer of radionuclides as drilling progressed. Significantly, logging did not reveal anomalously high levels of gamma activity in any of these wells. 
Table 8.--Results of spectral logging of wells in burial grounds 5 and 6

[Position: B, Behind casing; O, Open bore]

\begin{tabular}{|c|c|c|c|c|c|c|c|c|c|c|c|}
\hline Well & Date & $\begin{array}{l}\text { Well } \\
\text { depth } \\
\text { (feet) }\end{array}$ & $\begin{array}{l}\text { Depth of } \\
\text { spectra } \\
\text { (feet below } \\
\text { land surface) }\end{array}$ & $\begin{array}{l}{ }^{137} \text { Cs } \\
\text { Identified } \\
\text { (indicated } \\
\text { by } X \text { ) }\end{array}$ & Position & Well & Date & $\begin{array}{l}\text { Well } \\
\text { depth } \\
\text { (feet) }\end{array}$ & $\begin{array}{l}\text { Depth of } \\
\text { spectra } \\
\text { (feet below } \\
\text { land surface) }\end{array}$ & $\begin{array}{l}{ }^{137} \mathrm{Cs} \\
\text { identified } \\
\text { (indicated } \\
\text { by } \mathrm{X} \text { ) }\end{array}$ & Position \\
\hline \multicolumn{12}{|c|}{ Burial Ground 5} \\
\hline 174 & $02-17-76$ & 125 & $\begin{array}{r}40.4 \\
116.9\end{array}$ & $x$ & 0 & 177 & $02-17 \cdot 76$ & 149 & $\begin{array}{r}72.5 \\
97.4 \\
142.8\end{array}$ & & \\
\hline 175 & $02-17-76$ & 148 & 42.4 & & & 178 & $02-18-76$ & 153 & 43.2 & & \\
\hline \multirow[t]{22}{*}{176} & $02-17-76$ & 143 & $\begin{array}{l}39.8 \\
63.3\end{array}$ & & & & & & $\begin{array}{c}151.7 \\
.\end{array}$ & $x$ & 0 \\
\hline & & & 140.1 & $x$ & 0 & 419 & $02-18-76$ & 17 & 9.5 & $x$ & 8 \\
\hline & & & $\begin{array}{l}140.5 \\
143.8\end{array}$ & $x$ & 0 & & & & 12.2 & $x$ & B \\
\hline & & & & & & $458 \mathrm{a}$ & $06-06-78$ & 150 & 105.8 & & \\
\hline & $06-05-78$ & & 128.4 & & & & & & 123.5 & & \\
\hline & & & $\begin{array}{l}136.4 \\
137.4\end{array}$ & & & & & & 141.2 & & \\
\hline & & & 138.4 & $x$ & 0 & $459 a$ & $06-06-78$ & 150 & 8.1 & & \\
\hline & & & 139.4 & $x$ & 0 & & & & 70.8 & & \\
\hline & & & 140.2 & $x$ & 0 & & & & & & \\
\hline & & & 142.0 & $x$ & 0 & 460 & $06-06-78$ & 100 & $\begin{array}{l}19.2 \\
51.8\end{array}$ & & \\
\hline & $05-18-82$ & & 0.7 & & & & & & 90.6 & & \\
\hline & & & 16.0 & & & & & & & & \\
\hline & & & 24.9 & & & Buria & round 6 & & & & \\
\hline & & & 36.0 & & & & & & & & \\
\hline & & & 37.2 & & & 107 & $05-19-82$ & 122 & 15.0 & $x$ & B \\
\hline & & & 113.8 & & & & & & & & \\
\hline & & & 125.6 & & & 109 & $02-20-76$ & 126 & 50.6 & & \\
\hline & & & 138.4 & & & & & & 121.1 & & \\
\hline & & & 139.5 & $x$ & 0 & & & & & & \\
\hline & & & 140.6 & $x$ & 0 & 110 & $02-20-76$ & 125 & 28.7 & $x$ & B \\
\hline & & & 144.2 (in $\mathrm{m}$ & & & & & & & & \\
\hline & 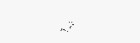 & & & & & 279 & $02-20-76$ & 10 & 4.8 & & \\
\hline
\end{tabular}

It is important to note that the logging equipment used is able to identify only those gamma emitters with sufficient energy to appear above the Compton continuum. Alpha, beta, and low-energy gamma emitters appearing below that continuum, if present in the well, would not be detected.

\section{Radiochemical Analyses of Ground Water}

Water samples were taken from 17 wells in the piezometer arrays in August 1983 for analyses of many stable ions and selected radionuclides. Three wells $(461,462$, and 463$)$ were not sampled at that time because the casings had 
recently been extended to a height of 20 feet above land surface which made them inaccessible to pumping, and one well (465), after evacuating the water stored in the casing, was found to recharge so slowly that a valid sample could not be obtained. The analyses of the radioactive constituents are considered here because these substances provide information about ground-water flow, particularly at depth; the analyses of the stable ions are considered later under the heading, Ground-Water Quality.

Analyses were made for the following radiochemical parameters: total alpha, gross beta, tritium, strontium-90, cobalt-60, cesium137, and antimony-125. Each of these radionuclides and types of radioactivity had been found in samples of well water and seepages analyzed during previous studies of this site.

Tritium $\left({ }^{3} \mathrm{H}\right)$ is a radioactive isotope of hydrogen that is produced naturally in small quantity in the atmosphere. It is usually found in very small concentrations in the ground and surface waters of the Earth as a result of recharge (precipitation) entering these systems. Tritium also is widely produced in the nuclear industry, and waste containing large amounts of this radionuclide have been interred in burial ground 5 . Strontium-90, cobalt-60, cesium- 137 , and antimony-125 are associated with nuclear research and development activities. Unlike tritium, these isotopes do not occur naturally in water and, when found in that medium, are uniquely associated with waste-disposal activity.

The analytical results are given in table 9 in four groups, with each successive group representing a greater depth interval. The analyses show that the concentrations of total alpha, ${ }^{60} \mathrm{Co}$, ${ }^{137} \mathrm{Cs}$, and ${ }^{125} \mathrm{Sb}$ were below or close to the threshold level of detection in the well water sampled. However, water from five wells contained gross beta activity, which includes ${ }^{90} \mathrm{Sr}$, at levels higher than background; water from four wells contained very low concentrations of an unidentified beta emitter; and water from nearly all of the wells contained tritium in concentrations that range from very high to background.

It is the depth of occurrence and concentration of tritium in the well water that is of particular interest to developing a conceptual model of ground-water flow. When dissolved in ground water, tritium becomes part of the water molecule and then is transported in the form of HTO (where one atom of hydrogen $[\mathrm{H}]$ has been replaced by an atom of tritium [T]) at essentially the same velocity as ground water. The amount removed from the migrating solution by replacement of nontritiated water on clays and other hydrated soil constituents is marginal (Ames and Rai, 1978, p. 3-222). Thus, the present distribution and concentration of this radionuclide in ground water are useful as indicators of the relative amount of total recharge entering bedrock from the regolith (the place of waste burial) and the depth of ground-water circulation.

The data show that the highest concentrations of tritium were found in the shallow regolith wells, moderately high concentrations were found in the 100-foot piezometers of the central and north clusters, and very low or background concentrations were found in the 150- and 200foot piezometers. At the west cluster, which is about 250 feet from the burial area, relatively little tritium was found in the regolith well and 
Table 9.--Radiochemical analyses of well water, burial ground 5

[Cluster identification: C, Central; S, South; W, West; N, North; E, East. Analyses were performed under the supervision of T.G. Scott, Analytical Chemistry Division, Oak Ridge National Laboratory, Tennessee. Results are reported in Bq/L]

\begin{tabular}{llllllll}
$\begin{array}{l}\text { Well } \\
\text { No. Cluster } \begin{array}{c}\text { Depth } \\
\text { (feet) }\end{array}\end{array}$ & $\begin{array}{c}\text { Total } \\
\text { alpha }\end{array}$ & $\begin{array}{c}\text { Gross } \\
\text { beta }\end{array}$ & ${ }^{3} \mathrm{H}$ & ${ }^{90} \mathrm{Sr}$ & ${ }^{60} \mathrm{Co}$ & ${ }^{137} \mathrm{Cs}$ & ${ }^{125} \mathrm{Sb}$ \\
\hline
\end{tabular}

Samples collected during February-March 1979:

$\begin{array}{llrlccc}458 B & C & 150-202 & 1.2 \pm 1.3 & <33.3 & 3.7 \times 10^{2} & 5 \\ 460 A & C & 44-100 & 1.0 \pm 1.3 & <50 & 4.7 \times 10^{5} & 3.0 \pm 3.7\end{array}$

Samples collected during August 1983:

\begin{tabular}{|c|c|c|c|c|c|c|c|c|c|}
\hline $\begin{array}{l}439 \\
440 \\
464 \\
468 \\
472 \\
476\end{array}$ & $\begin{array}{l}C \\
C \\
S \\
W \\
N \\
E\end{array}$ & $\begin{array}{r}24-34 \\
26-36 \\
6-11 \\
10-15 \\
15-20 \\
25-30\end{array}$ & $\begin{aligned} 1.6 & \pm 3.8 \\
9.2 & \pm 8.3 \\
5.6 & \pm 6.2 \\
2.7 & \pm 4.8 \\
1 & \pm 3 \\
5.7 & \pm 5.8\end{aligned}$ & $\begin{aligned} &< 20 \\
& 44 \pm 28 \\
& 26 \pm 25 \\
&<20 \\
& 25 \pm 25 \\
& 500 \pm 60\end{aligned}$ & $\begin{aligned} & 1.6 \times 10^{6} \pm .1 \times 10^{6} \\
& 6.4 \times 10^{5} \pm .1 \times 10^{5} \\
& 2.2 \times 10^{7} \pm .1 \times 10^{7} \\
& 350 \pm 60 \\
& 5.2 \times 10^{4} \pm .1 \times 10^{4} \\
& 5.3 \times 10^{5} \pm .1 \times 10^{5}\end{aligned}$ & $\begin{aligned} .30 & \pm .23 \\
29 & \pm 2 \\
5.6 & \pm .8 \\
.08 & \pm .15 \\
.27 & \pm .25 \\
410 & \pm 10\end{aligned}$ & $\begin{array}{c}<.06 \\
<.02 \\
<.05 \\
<.09 \\
<.08 \\
.14 \pm .06\end{array}$ & $\begin{aligned} & .087 \pm .018 \\
& .10 \pm .07 \\
&<=.04 \\
&<.07 \\
& .057 \pm .048 \\
& .048 \pm .027\end{aligned}$ & $\begin{array}{l}<.1 \\
<.2 \\
<.09 \\
<.1 \\
<.2 \\
<.1\end{array}$ \\
\hline $\begin{array}{l}460 \\
467 \\
471 \\
475\end{array}$ & $\begin{array}{l}C \\
W \\
N \\
E\end{array}$ & $\begin{array}{l}90-100 \\
91-101 \\
89-99 \\
90-100\end{array}$ & $\begin{aligned} 3 & \pm 3 \\
2.3 & \pm 3.9 \\
3.5 & \pm 4.8 \\
1.3 & \pm 2.7\end{aligned}$ & $\begin{array}{c}<25 \\
19 \pm 24 \\
47 \pm 27 \\
39 \pm 26\end{array}$ & $\begin{aligned} 2.2 \times 10^{4} & \pm .1 \times 10^{4} \\
14 & \pm 37 \\
8.1 \times 10^{5} & \pm .1 \times 10^{5} \\
740 & \pm 70\end{aligned}$ & $\begin{array}{l}.24 \pm .18 \\
.12 \pm .14 \\
.29 \pm .39 \\
.07 \pm .12\end{array}$ & $\begin{array}{l}<.07 \\
<.1 \\
<.07 \\
<.08\end{array}$ & $\begin{array}{c}<.05 \\
<.1 \\
.036=.033 \\
<.06\end{array}$ & $\begin{array}{l}<.1 \\
<.2 \\
<.1 \\
<.1\end{array}$ \\
\hline $\begin{array}{l}459 \\
466 \\
470 \\
474\end{array}$ & $\begin{array}{l}\mathrm{C} \\
W \\
\mathrm{~N} \\
\mathrm{E}\end{array}$ & $\begin{array}{l}130-140 \\
142-152 \\
141-151 \\
142-151\end{array}$ & $\begin{aligned} 2 & \pm 3 \\
1.3 & \pm 3.2 \\
1 & \pm 3 \\
1.1 & \pm 2.5\end{aligned}$ & $\begin{array}{c}25 \pm 24 \\
.57 \pm .21 \\
<25 \\
70 \pm 30\end{array}$ & $\begin{array}{l}250 \pm 50 \\
33 \pm 38 \\
77 \pm 41 \\
33 \pm 38\end{array}$ & $\begin{array}{l}.38 \pm .22 \\
.15 \pm .17 \\
.24 \pm .15 \\
.05 \pm .12\end{array}$ & $\begin{array}{l}<.06 \\
<.09 \\
<.1 \\
<.1\end{array}$ & $\begin{array}{l}<.05 \\
<.07 \\
<.08 \\
<.09\end{array}$ & $\begin{array}{l}<.1 \\
<.1 \\
<.2 \\
<.2\end{array}$ \\
\hline $\begin{array}{l}458 \\
469 A \\
473\end{array}$ & $\begin{array}{l}C \\
N \\
E\end{array}$ & $\begin{array}{l}190-202 \\
191-201 \\
190-200\end{array}$ & $\begin{aligned} 3 & \pm 3 \\
4 & \pm 3 \\
3.1 & \pm 5.2\end{aligned}$ & $\begin{array}{c}<20 \\
21 \pm 24 \\
<20\end{array}$ & $\begin{array}{c}21 \pm 37 \\
190 \pm 50 \\
92 \pm 42\end{array}$ & $\begin{array}{c}.99 \pm .33 \\
<.2 \\
.03 \pm .10\end{array}$ & $\begin{array}{c}<.09 \\
.085 \pm .076 \\
<.09\end{array}$ & $\begin{array}{c}<.8 \\
.10 \pm .07 \\
<.07\end{array}$ & $\begin{array}{l}<.2 \\
<.2 \\
<.1\end{array}$ \\
\hline
\end{tabular}


essentially none in the bedrock wells. Bedrock wells of the south cluster were not sampled. The data show a pronounced decrease in tritium concentration as depth increases, and the decrease is marked between the 100- and 150-foot levels.

To a lesser extent the analyses of the other radionuclides also are indicators, but they are not as useful because much smaller quantities of them have been buried and the metallic isotopes listed in the table have distribution coefficients significantly higher than that of tritium, indicating that sorption or ion exchange will retard their transport in circulating ground water. Strontium-90, which has the lowest distribution coefficient of the four metals for the local clays, is present in concentrations greater than $1 \mathrm{~Bq} / \mathrm{L}$ (Bequerel per liter) only in wells 440,464 , and 476 , the regolith wells of the central, south, and east clusters, respectively. In only one bedrock well does its concentration approach $1 \mathrm{~Bq} / \mathrm{L}$. The gross beta data generally follow the ${ }^{90} \mathrm{Sr}$ data except at the east cluster where an unidentified beta emitter is present in water from the 150 -foot piezometer.

The analytical results reveal that most of the dissolved radionuclides transported from the buried waste are contained within the regolith part of the aquifer. Some of the activity has been carried as deep as 100 feet, which is substantially below the top of bedrock. Only minor concentrations are found at depths of 150 and 200 feet.

\section{CONCEPTUAL MODEL OF FLOW: THE BEDROCK}

\section{Burial ground 5}

The initial concept of the bedrock hydrology of the Conasauga Shale resulted from studies made of the Four-Acre site (fig. 1) and the ILW-disposal area during the 1950's. Those studies are reviewed here because they provide the foundation for the conceptual model of ground-water flow in the bedrock given in this report.

The hydrologic characteristics of the bedrock underlying the Four-Acre site were investigated by drilling a well 300 -feet deep, and coring four satellite wells, each of 200 feet depth, at points 200 feet to the east and west (along strike) and north and south (normal to strike) of the deeper well. The north well probably terminated in the Pumpkin Valley Shale; the others, in the Rutledge Limestone. In a water injection/packer test, the water levels in the wells along strike rose more than those normal to strike. Conversely, in a 48-hour pumping test, the water levels in the wells along strike declined about 7 to 20 times as much as those normal to strike. A tracer test, where chemicals were introduced into the west well and the central well was continuously pumped, provided a breakthrough time of 80 hours, but the tracer was still present in the discharge at 280 hours when the test was discontinued. Conclusions of the three tests were that (1) rock in the vicinity of the wells is virtually impermeable below a depth of 100 feet and incapable of transmitting water under natural hydraulic gradients; (2) the water-bearing fractures are interconnected to some degree; 
(3) water moves more readily along strike than across it; (4) the porosity of the rock is quite small; and (5) the rock between the two tracertest wells contains a number of separate but interconnecting passageways, enabling some of the tracer to come through directly while some of it follows more circuitous routes (deLaguna and others, 1958; unpublished manuscript in files of USGS).

Later, a similar array of wells was constructed at the site for ILW pit 4 before the pit was excavated. All of the wells were drilled in the Maryville Limestone; again, all of the observation vells were 200 feet deep. Injection tests showed that the rate of acceptance of water at depths greater than 120 feet was very low (maximum of $0.4 \mathrm{gpm}$ at $30 \mathrm{lb} / \mathrm{in}^{2}$ head per 10-foot interval of well) in three wells and zero in the other two wells. Response of the satellite wells to injection at the central well is undocumented by available records. Several pumping tests indicated that the permeability of the rock between the central well and the north well (normal to strike) is very low and less than that in the direction of strike (the east-west wells), and that no hydraulic connection exists in the "deeper" rock between the central well and the south well. The latter may be due to a fault that is thought to lie between the two wells (deLaguna and others, 1958, p. 106-108).

The results of the aquifer tests at these sites and other evidences of flow that pertain mainly to the regolith were interpreted by later investigators to mean that the principal direction of fluid flow in the Conasauga Group of Melton Valley is parallel to formation strike. This projection of the results to other areas in the valley should be viewed with caution inasmuch as (1) the natural hydraulic gradient at the ILW area does not differ greatly from strike and, therefore, the concept was not put to a rigorous test; (2) a suspected fault just south of ILW pit 4, where gradient and strike are approximately normal to each other, was thought to be a hydraulic barrier and, therefore, the pumping test analyses and absence of a waste plume in that direction do not provide results representative of the entire formation; (3)the direction of flow under natural gradients may or may not replicate that under the stressed conditions of an aquifer test; and (4) the beds have secondary openings both between and across them which logically should permit multidirectional flow.

It is this last factor that is considered in some detail here. The principal pathways for flow in the bedrock are fractures, joints, faults, and solution openings. The openings between the beds--largely bedding-plane faults, fractures, and to some extent solution openings--have developed along zones of inherent weakness. They tend to have lateral continuity, although the lengths of individual openings are highly variable, and lineation that trends in the direction of formation strike. Joints and fractures, in terms of numbers, are the principal openings that cross the beds, but they are not persistent over distance. Haase (AAPG proceedings, 1981, unpublished), in discussing the Pumpkin Valley Shale, observed that even though that formation is locally highly fractured, any one joint or fracture is contained within only a few beds. This probably is true of the majority of joints and fractures in other formations of the Conasauga Group, although those in the more substantial limestone beds probably are somewhat longer because the 
beds are thicker. The longest openings across the bedding result from faults, but faults in this direction are much less numerous than joints or fractures. Additional complexities arise from the tendency for certain lithologies to favor one type of opening over another, and a possible relationship between lithology and the amount of secondary mineralization filling the openings. There also is variability with depth, although the trend is for openings to become tighter and to pinch out as depth increases. This is evidenced by the packer/injection tests of the 1950's and the measurements of hydraulic conductivity in this study.

The picture that emerges from the results of the various field studies is a heterogeneous, anisotropic aquifer in which the laterally-continuous openings between the beds provide the more significant pathways for flow. Superimposed upon them are openings that cross the beds, but in the bedrock these openings appear to be less numerous than they are in the regolith, and most are of short length. Consequently, other factors being equal, fluids move with greater ease between the bedding planes than across the beds. This was demonstrated by the pumping tests and the packer/injection tests. Flow also must occur across the beds when a potentiometric gradient in that direction exists, although it is relatively more difficult for fluid to do so because of the spacing, width, and discontinuous nature of the openings. Although flow in the bedrock may appear to parallel strike over relatively short distances (i.e., 200 feet) between observation wells, actual net pathways of flow in areas as large as an entire burial-ground where hydraulic gradients cross the bedding probably occur at some angle to strike. If a particle of water could be traced as it moves through the bedrock, its overall path probably would be found to follow an irregular stair-step pattern as suggested for some of the more resistant intervals of the lower regolith. The actual path taken must be governed by the three-dimensional geometry of the network of openings and the distribution of hydraulic head within that system.

The conceptual model described under "Hydrology of the regolith" can thus be developed further by adding a third zone as follows:

(3) A zone comprising the water-bearing section of the bedrock where the largest component of flow occurs in openings between the beds and, therefore, its vector trends in the direction of formation strike; where a potentiometric gradient crosses the beds, which probably is characteristic of much of the disposal areas, a smaller secondary component of flow and its vector also crosses the beds, and the resultant direction of flow is at some angle to strike and toward points of lower hydraulic head. This zone extends to more than 200-feet depth, giving it the greatest thickness of the three zones, but the total flow through this zone probably is less than that in zones (1) and (2) combined.

This interpretation of results from previous and on-going studies implies that it is quite possible for the direction of ground-water flow to change with depth. In the uppermost part of the saturated zone, the direction of the largest component of flow corresponds to the inferred water-table gradient throughout much of the area. (The actual direction of flow is determined 
by the real gradient within the network of pathways through which water flows.) As depth below the water table increases, the direction of flow becomes increasingly governed by the hydraulic gradients within the partings, joints, fractures, solution openings, and other pathways of flow. Thus, the overall direction of ground-water flow in the regolith may differ from that at a point 100 or 200 feet below. The potential for difference is greatest where the gradient inferred from water-level data of wells trends normal to strike. This may be illustrated by diagrams (fig. 31 ) showing conceptual flow paths in both the regolith and bedrock with gradients equal in magnitude but 90 degrees different in direction. In both diagrams strike is assumed to be east-west. The gradient in (a) is north to south, normal to strike. Flow in the regolith is fairly direct from point $P$ to point $P^{\prime}$, being skewed to a comparatively minor degree by anisotropy of the regolith. Flow in the bedrock trends to the southwest, following openings in the bedrock from point $\mathrm{P}$ to point $\mathbf{P}^{\prime \prime}$. Without more detail on the magnitude and direction of the gradient than that given, the direction of flow from point $P$ also could be to the southeast in a similar pattern instead of to the southwest. The distance between points $\mathbf{P}^{\prime}$ and $\mathrm{P}^{\prime \prime}$ is a function of the difference in degrees of anisotropy between the regolith and bedrock. In figure 31 (b) the gradient is from east to west, parallel to strike. Again, flow in the regolith is fairly clirect. Flow in the bedrock under this condition is primarily through openings between beds, being diverted where individual openings constrict or terminate or by local changes in hydraulic gradients within the bedrock system. The potential for differences in the direction of flow paths between regolith and bedrock then becomes much less than in (a).
All fluid flow is three-dimensional, having both lateral and vertical components. The overall direction of the lateral component of flow in the burial ground 5 bedrock can be inferred by plotting the altitude of the static potentiometric surfaces at the 100-, 150-, and 200-foot wells of each cluster. For dates when head data are available, the net gradient thus shown at the site is toward the southwest part of the burial ground and beyond. This is consistent for each horizon, although data for some of the 200-foot piezometers are limited and have to be estimated on the basis of other record. Because the potentiometric heads decrease to the southwest, it is inferred that the net direction of the lateral component of flow must be to the southwest. Individual pathways of flow, of course, may change direction many times along their length, such as is shown in figure 31 (a).

The vertical component of flow can be illustrated by constructing sectional diagrams of the potentiometric heads, as is shown in sections $A-A^{\prime}$ and $B^{\prime}-B$ of figure 32 . Section $A-A^{\prime}$ shows the vertical distribution of heads along a line from Whiteoak Creek, through the west, central, and east clusters, to a point just east of the drainage on the east side of the burial ground. It is based on water-level data of the water-table wells throughout the site and the piezometers on July 14,1983 . This is the only date reflecting typical mid-season conditions that data from both the water-table wells and most of the piezometers are available. The altitudes of the potentiometric surfaces in the 200 -foot piezometers in the east and west clusters for this date have been estimated, as stated previously. A waste-slurry injection at the hydrofracture plant on the previous day caused potentiometric 


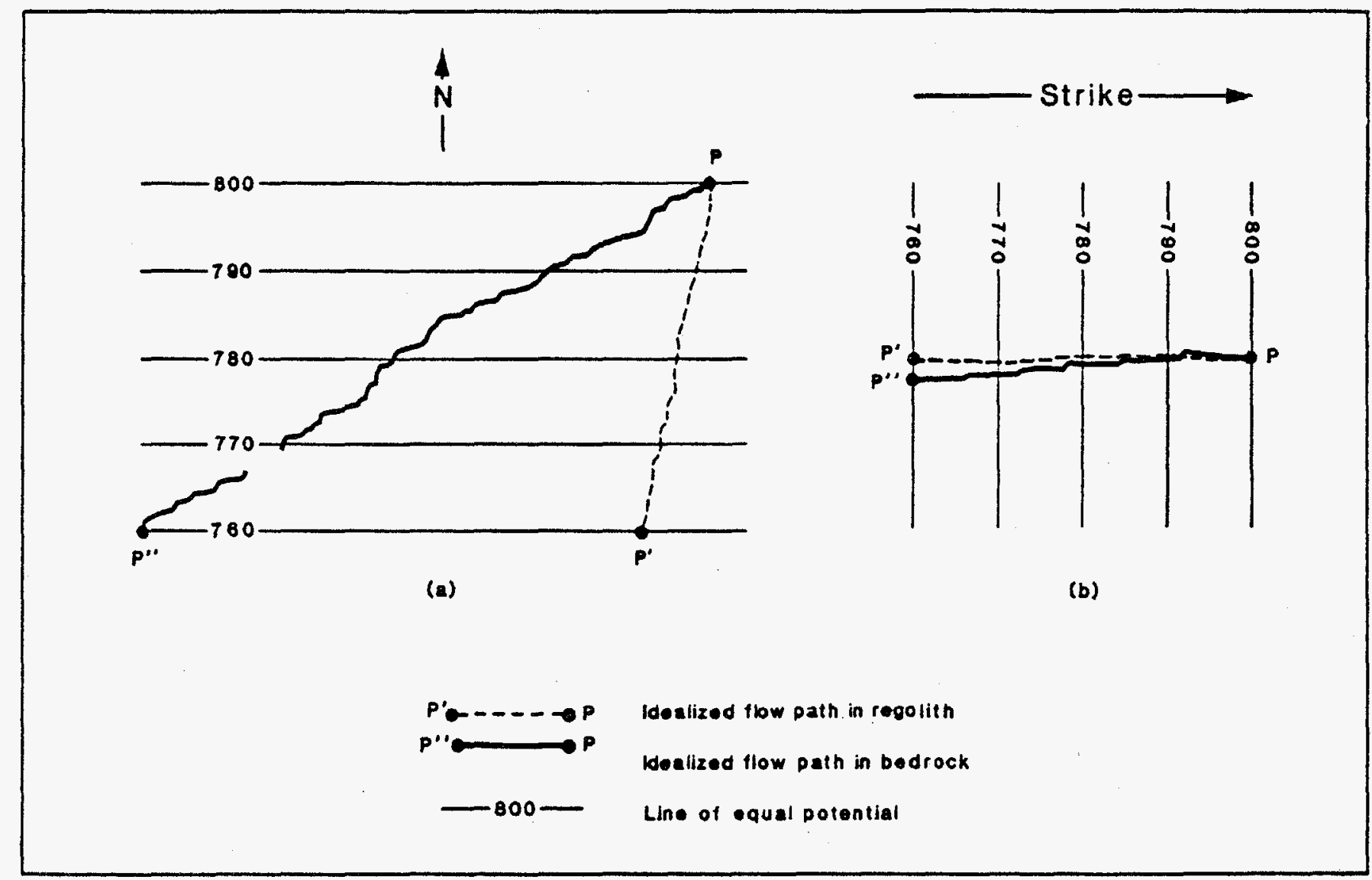

Figure 31.--Diagrams illustrating conceptual pathways of ground-water flow in the regolith and bedrock where the inferred water-table gradient is (a) normal to strike, and (b) parallel to strike. 


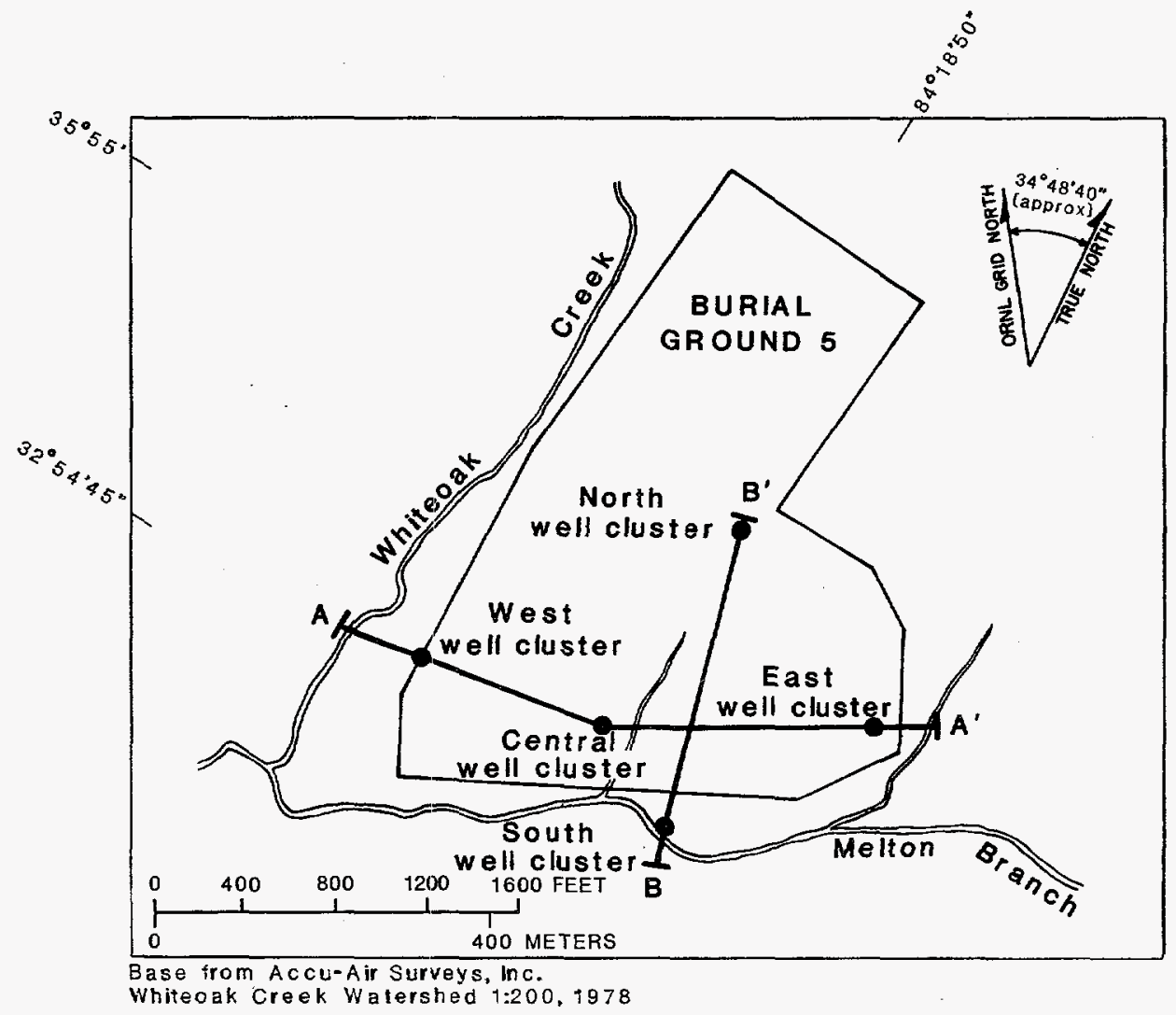

\section{EXPLANATION}

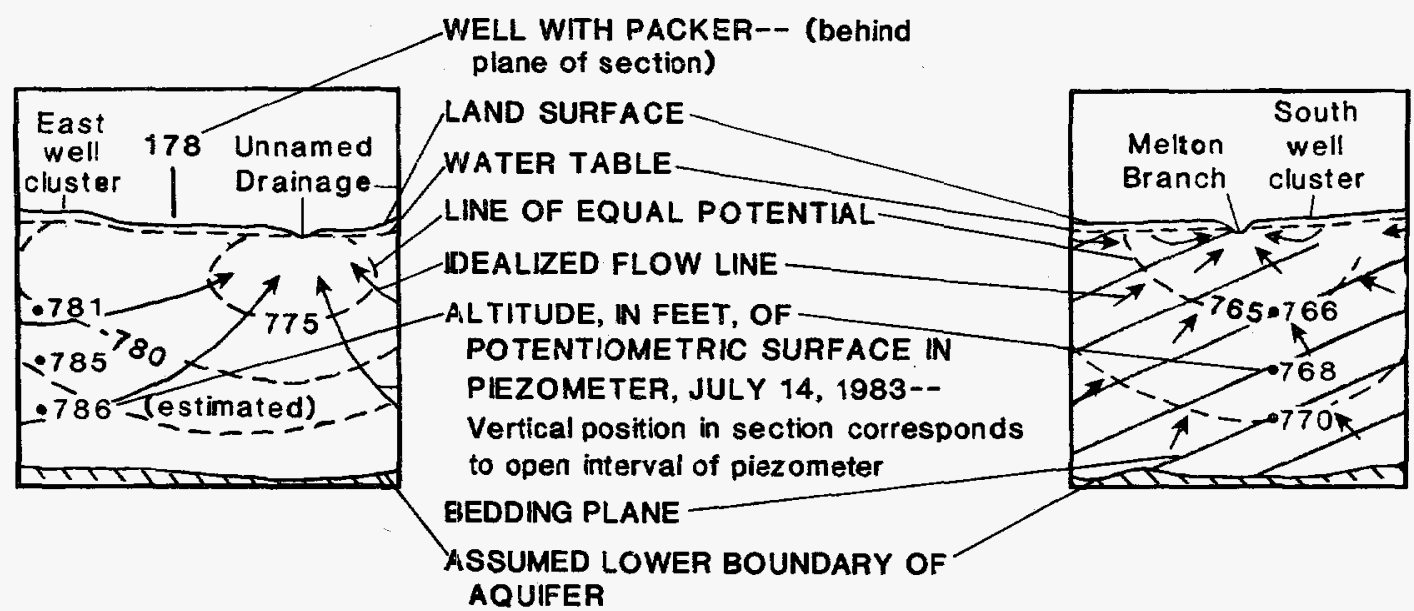

Figure 32.--Diagrammatic sections of burial ground 5 showi 
West Lobe

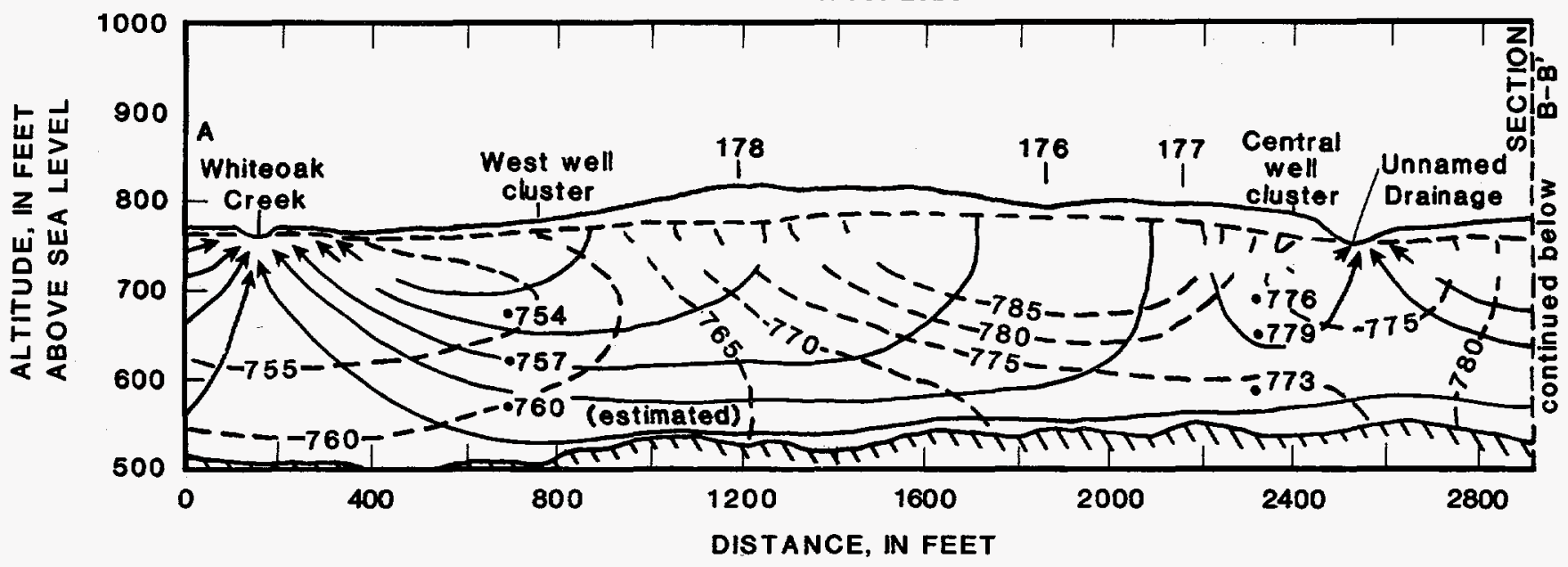

East Lobe
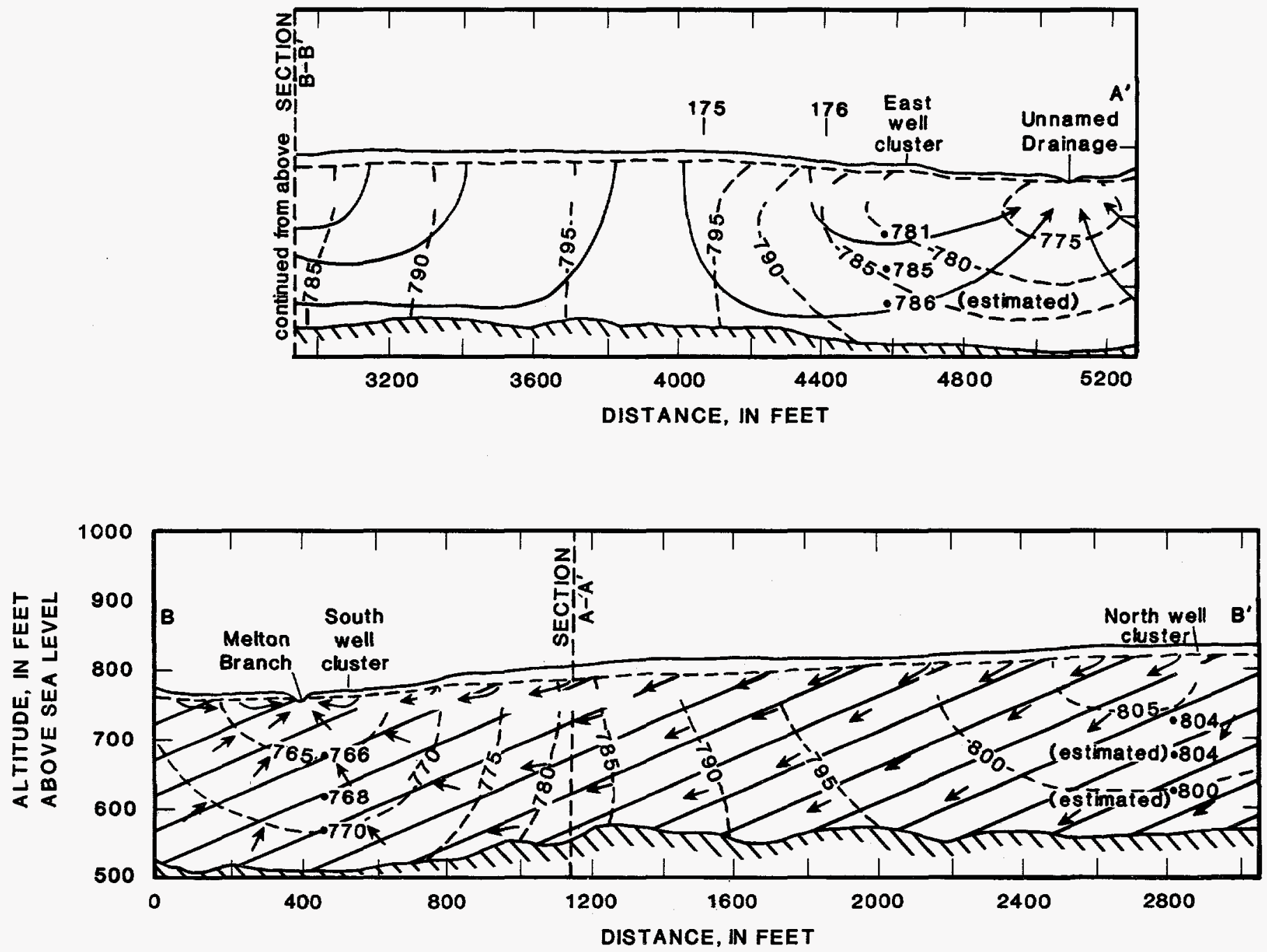

head distribution and idealized flow paths in the vertical direction. 
surfaces in some of the piezometers to change more than would have been normal over one day, but the continuous data show that the extent of changes are minor and insufficient to alter the head relationships shown. In well 458 , the piezometer that available record shows is most affected, the water level had declined by about 0.3 foot on this date. Four hydrologic boundaries are shown on the illustration. One is the water table; the second is an irregular surface at about 250 feet depth representing assumed, impermeable bed-rock, a no-flow boundary; the third is a ground-water divide under the east lobe; and the fourth is the network of streams along three sides of the site (Whiteoak Creek and the unnamed stream east of burial ground 5 , as shown in section A-A', and Melton Branch, shown in section $\left.B^{\prime}-B\right)$. Inasmuch as the same water-level data were used to construct the ground-water contour map (fig. 17), the equipotential lines in this diagram are an extension in the vertical plane of the same equipotential lines that are shown in the two lateral dimensions of that map. The flow lines do not cross the equipotential lines at right angles because of the anisotropy that exists in the bedrock, as has been demonstrated by the hydraulic tests.

The illustration reveals several features about ground-water flow in the bedrock below the site. First, the flow lines show that this part of the burial ground is underlain by four local flow cells. In the TRU area to the north, the number of cells probably is less, as will be shown in figure 33. The depth to the lower boundary of the aquifer is simply too shallow relative to the difference in potentiometric heads between top and bottom for regional or even intermediate distance flow systems to develop.
The flow lines also indicate that the bedrock receives recharge from the regolith along more than 80 percent of the line of section; only along strips adjacent to the drainages does the bedrock discharge water to the regolith and the drainages. Discharge along this section is into three drainages: Whiteoak Creek, the drainage that divides the burial ground into east and west lobes, and the drainage near the east perimeter of the site. Had the section been made more southerly along Melton Branch, it would indicate discharge into that stream, as is implied in section B'-B. Had the section been made more northerly across the nearly perennial stream in the TRU area (for which potentiometric head data at depth are not available), it probably would indicate discharge into that stream and Whiteoak Creek. Within the flow cells illustrated there may be some local, anomalous flow patterns (or small cells) resulting from bands of very-low permeability rock, structural dislocations, or solution cavities may occur within this system. These anomalies, if present, are superimposed upon the overall flow pattern and are analagous to eddy currents in a stream.

The section also shows that in the vertical plane the "area of influence" of each drainage is related to the magnitude of its discharge. The equipotential lines within the influence of Whiteoak Creek, the principal stream of this area, extend at depth across the width of the west lobe. Those within the influence of the unnamed drainage on the east, a smaller drainage, extend only about half that distance, and those within the influence of the central drainage, which conveys the least flow of the three, have a still smaller area and do not even extend to the lower 
boundary. This observation can be useful in projecting a section to other parts of Melton Valley for which potentiometric data are lacking.

The diagram illustrates the interpretation of the potentiometric head relations discussed earlier and reveals why the vertical component of flow changes direction at certain depths below the west and central clusters. At the west cluster, water in the upper bedrock moves both down and toward Whiteoak Creek, whereas in the lower part of the saturated zone water moves both up and toward that drainage. At the central cluster, water moves from the regolith into the upper bedrock and then discharges from it into the central, unnamed drainage. Water reaching the lower part of the saturated bedrock from points east and west of the upper zone's recharge area flows westerly to discharge to Whiteoak Creek.

The wells in which packers were placed are at varying distances to the north of section A-A: Although these wells are not in the plane of the section, and those water-level measurements were made before the measurements used to construct this illustration, their data also support the flow patterns shown.

Section $B^{\prime}-B$ (fig. 32) is a conceptualization of bedrock flow along a line of section from the north cluster, through the south cluster, to a point a short distance southeast of Melton Branch. Used in conjunction with section A-A', it describes flow patterns in a generally northsouth direction. This section is based on the water-level data of July 14,1983 , the flow pattern shown in section $A-A^{\prime}$, and the conceptual model described earlier. Because the potentiometric surfaces in the 150- and 200-foot piezometers of the north cluster had not reached static levels at that date, estimates of their mid-July 1983 altitudes are made ( 804 and 800 feet, respectively), based on later record. The attitude of the bedding planes as they typically cross the line of section is shown lightly in the background, although in actuality many folds, faults, and departures from average dip are likely intercepted within this line. In addition, joints and fractures, which are not shown, cross the beds, but for the most part lack continuity over any substantial sequence of rock.

Part 3 of the conceptual model states that the largest component of flow in bedrock occurs between beds and a smaller component of flow crosses them. In this line of section, a potentiometric gradient exists from the north cluster to Melton Branch. Flow characteristics as conceptualized are that (1) the greatest amount of flow occurs in the regolith, and this is shown by the numerous short, nearly horizontal arrows at shallow depth; (2) the regolith supplies water to the underlying material throughout the section except in the vicinity of the south cluster; (3) water moves into bedrock throughout most of the section, but as it moves downward, some portion of it continually turns from the plane of the paper to points of lower potential in the bedding planes, which cross the paper at a sharp angle; consequently, only a very small fraction of the water entering bedrock moves as deep as 250 feet, the assumed lower boundary; (4) water also crosses the beds through joints and fractures, but it is more difficult for flow to occur in this direction than between the beds because these openings have a smaller total area than those along the bedding planes and they lack continuity. With regard to (3) and (4), the reader should not 
interpret the diagonal arrows as representing linear, continuous, downward flow between the beds to the lower boundary of the aquifer. The net direction of flow by compositing sections A$A^{\prime}$ and $B^{\prime}-B$ would be drawn, if it were possible to portray three-dimensional flow in two dimensions, as arrow shafts crossing the beds at low to moderate angles, with the heads of the arrows curling out of the paper toward the viewer.

As considered previously, most water between the 100- and 150-foot zones at the north cluster probably moves laterally (that is, at an angle to the paper). This would be westerly towarcl the downstream half of the drainage between the 5-north and 5-south areas and southwesterly toward Whiteoak Creek. Recharge to the 200-foot level then must come from points of higher potential to the northeast, and discharge is into Whiteoak Creek. In the mid-section of section $\mathrm{B}^{\prime}$-B water in the upper and middle parts of the saturated zone discharges to the unnamed drainage between the east and west lobes, as indicated in the discussion of section A-A', and water that reaches the deeper part of the saturated zone in this area probably discharges to Whiteoak Creek. Near the south cluster and Melton Branch the direction of the potentiometric gradient reverses. Water in the deeper zone rises through whatever openings exist between and across the beds. The discharge point is Melton Branch, but because the openings are discontinuous, the net direction of flow probably is not to the drainage directly above as the twodimensional diagram suggests, but to the drainage at numerous points downstream. This would suggest that the water in the piezometers of the south cluster is not entering those wells by flow along the line of section $B^{\prime}-B$ as the topog- raphy of the burial site would suggest, but by flow from points of higher potential which lie to the north or northeast. It also can be inferred from the section that the pressure gradient in the bedrock of the area southeast of Melton Branch does not permit the flow of water from burial ground 5 to points under Copper Ridge and subsequent discharge to Melton Hill Lake.

\section{Melton Valley}

Data from numerous water-table wells and piezometers would be required to accurately construct detailed flow sections across the length of Melton Valley. Although such data are not available, the conceptual model of ground-water flow at burial ground 5 can be extended to other parts of Melton Valley on the basis of the relations described. On figure 33 three sections are shown. Section A-A' is a vertical section across burial ground 4, Whiteoak Creek, the TRU storage area of burial ground 5 , and the western part of the ridge to the east. Section B-B' extends from the summit of one of the ridges on the east side of burial ground 6, across the ILW-disposal area and Whiteoak Creek, to a point inside burial ground 5. Section C-C' extends from a point just west of Watts Bar Reservoir (the Clinch River) at Jones Island to the drainage between burial ground 6 and the ILW pit area.

The assumed water-table position through the three sections is based on water-level measurements of the burial grounds and adjacent areas that have topography generally similar to the areas depicted. For example, the position of the water table through much of section $\mathrm{A}-\mathrm{A}^{\prime}$ is based on typical mid-season data of burial 
ground 4, the Whiteoak Creek flood plain, and the TRU area of burial ground 5. In the area east of the burial ground 5 boundary, for which data are not available, its position reflects the same slope as that below the TRU area and the relation found in the Melton Valley disposal sites that depth to water increases as surface altitude increases. Similarly, the water-table position at the end points of sections B-B' and C-C' ${ }^{\prime}$ is based on typical mid-season water-level data of burial grounds 5 and 6 , and its position across the intervening area upon the depth-to-water/surfacealtitude relation. The location of the equipotential lines as they cross the vertical plane is approximate. At their intersection with the assumed water table, their location corresponds to water-table contours (or equipotential lines) of the same value. Their position and character in depth is based on observations noted previously under the discussion of burial ground 5 bedrock hydrology, particularly the relation between magnitude of discharge of a drainage and the subsurface area (or size of the flow cell) influenced by that drainage. The lines showing vertical flow in figure 33 thus are not based on actual potentiometric data at depth, but upon generalized data and projection to these areas of the interpretation of the burial ground 5 flow model. While the construction of numerous piezometers and a period of data collection would be required to refine the location of the equipotential and flow lines, the illustration provides the foundation for an initial conceptualization of ground-water flow beyond burial ground 5 that may be modified by the results of continuing study.

Section A-A' shows virtually horizontal flow through the bedrock underlying burial ground 4, with discharge into Whiteoak Creek. Only near the western end of the site (near point A) is there any potential component of recharge, and this is to the shallow rock. The deeper rock is recharged from points of higher head on Haw Ridge (fig. 1). The three small drainages that cross the site, therefore, are not thought to contribute to bedrock recharge. To the east, the higher ridges east and north of the 5-north area are the source area for recharge in the deeper bedrock below the TRU storage area. The shallower rock is recharged by local flow cells from the ridge inside the TRU area. Discharge from the bedrock of these areas is to the local drainage within the TRU area and to Whiteoak Creek.

Section B-B' illustrates the effects of topography upon the development of flow patterns. Note that the water table below each summit occurs at about the same altitude; consequently, the heads through this area are about equal. Flow then is from the ridges (the recharge areas) to the nearby drainages. The difference in heads from ridge to ridge is too small to provide the driving force required for the development of deep flow to points beyond the local drainage system. One point in particular may be noted. In view of the apparent relation between a stream's magnitude of discharge and "area of influence", this model suggests that Whiteoak Creek at points near its confluence with Melton Branch may receive effluent from ILW trench 7 by virtue of deeper flow under the spur east of that disposal facility. This is in addition to shallow flow known to discharge to the small drainages east and west of ILW trench 7.

Section C-C' shows a ground-water divide in the bedrock underlying the ridge in the 


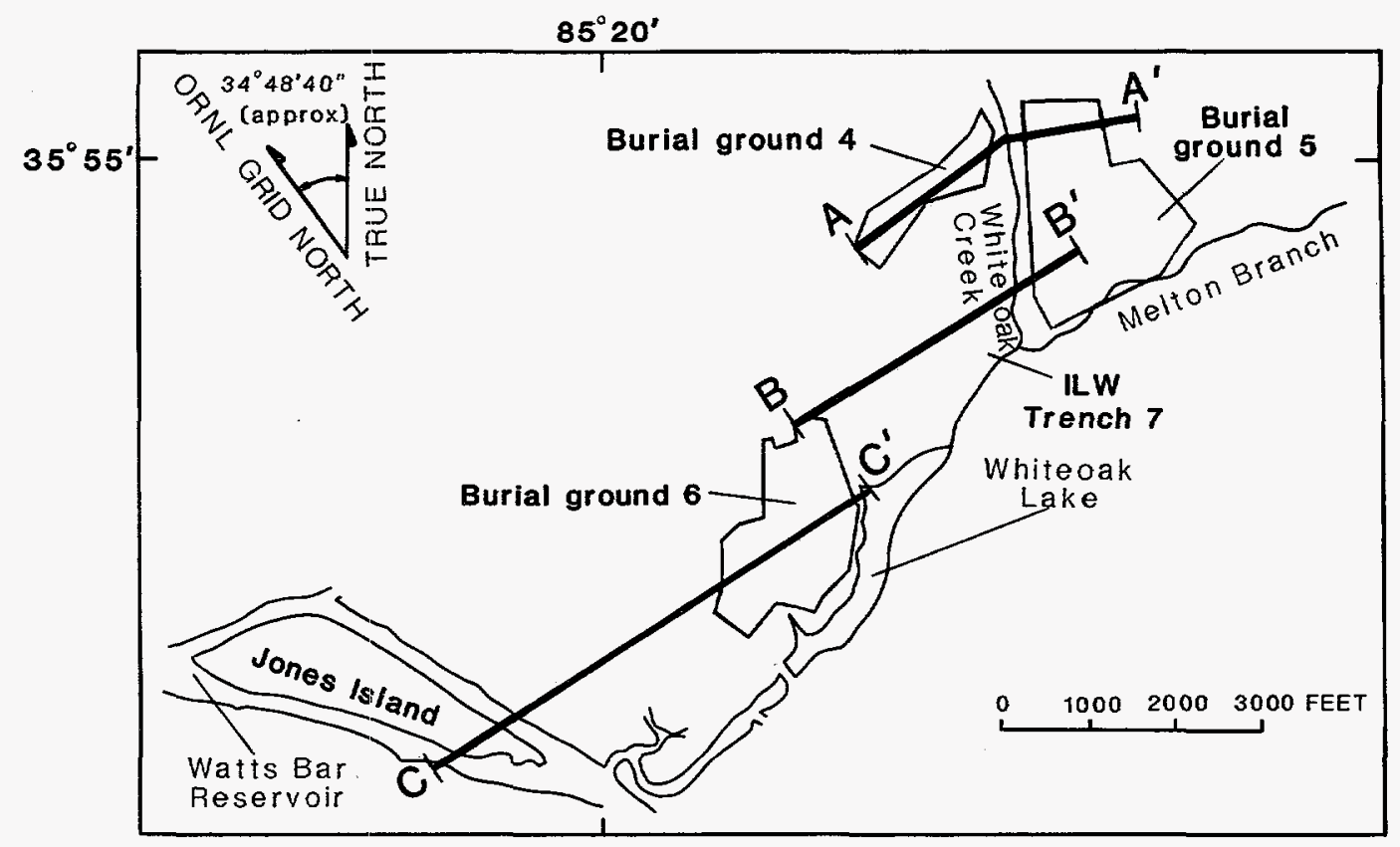

EXPLANATION
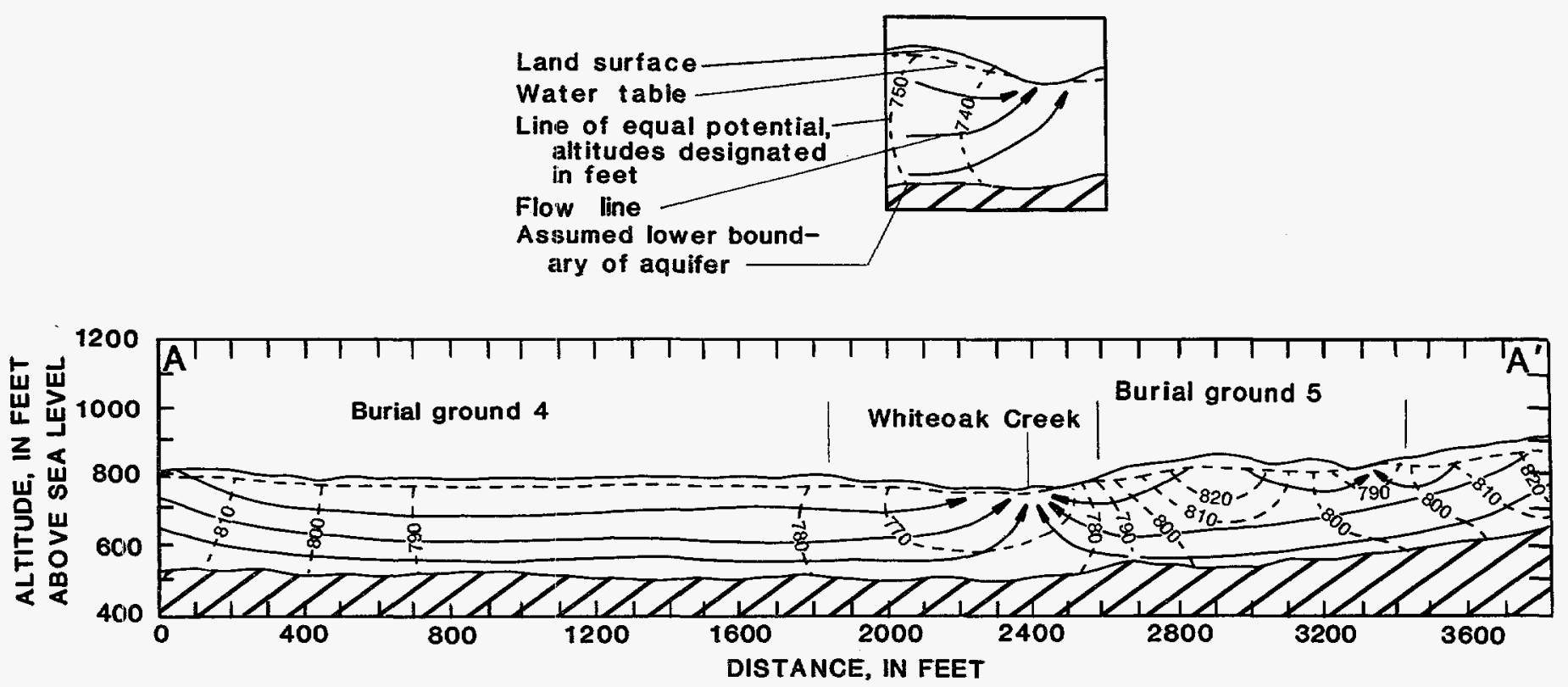

Figure 33.--Diagrammatic sections across burial grounds 4 and 6 and th ground-water flow patterns in the bedrock by projectic 

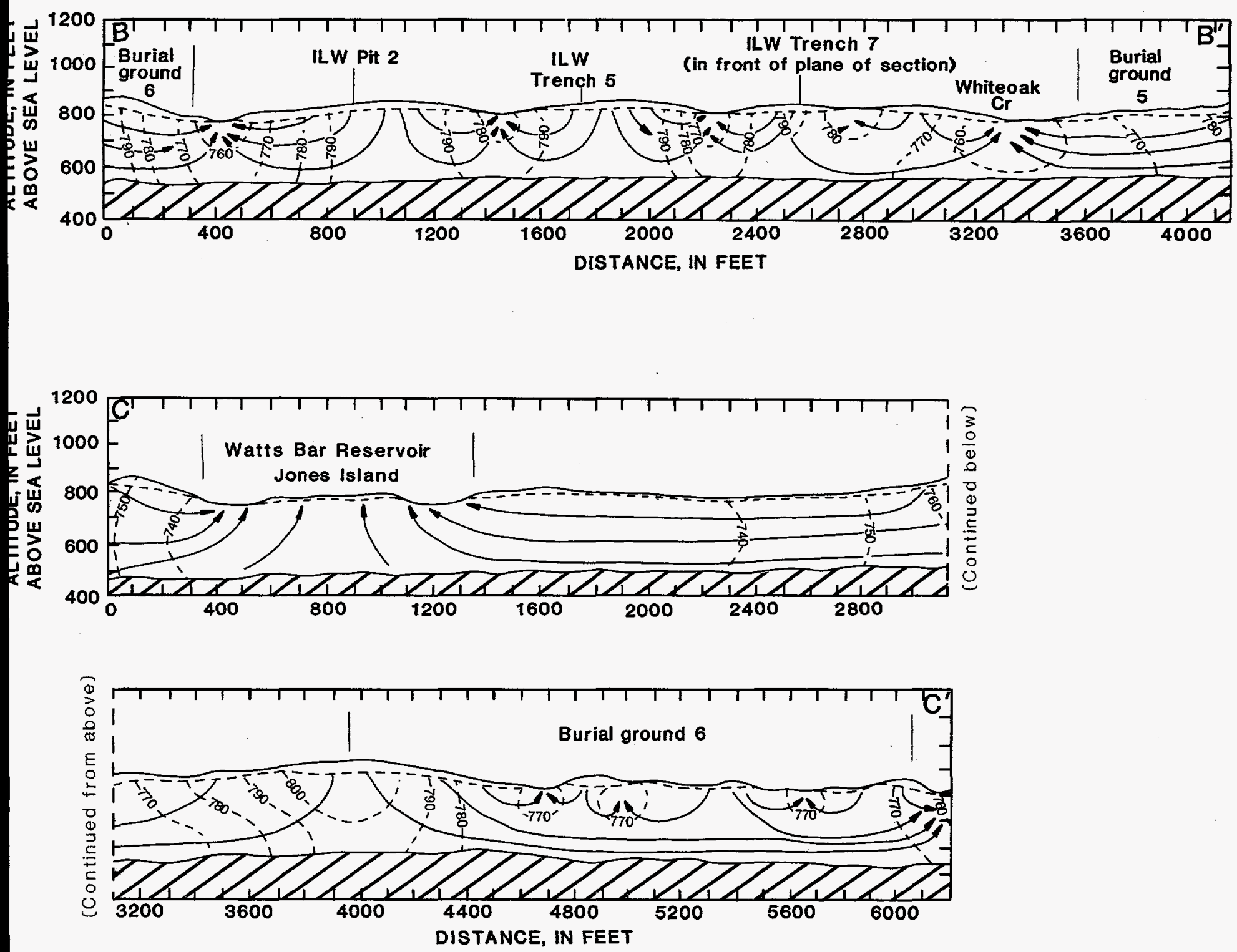

intermediate-level liquid waste (ILW) disposal area showing hypothesized of the conceptual model of burial ground 5 . 
northwest corner of burial ground 6. Water flowing northeasterly from the divide area recharges the deeper bedrock, flows under the site, and discharges to the drainage on the east side between burial ground 6 and ILW pits 2, 3, and 4. Some component of this recharge probably discharges to Whiteoak Lake also. Areas within burial ground 6 provide recharge to the shallower bedrock and discharge to the small drainages within the site and to the lake. Water flowing southwesterly from the divide area recharges the deeper bedrock of that locale and discharges to Watts Bar Reservoir and the regolith below the Clinch River flood plain.

Each of the three sections hypothesizes that water flows through the bedrock in flow cells of local area, as has been shown for burial ground 5. Discharge from the bedrock throughout the system is to the local drainages. Deep interbasin flow through the bedrock, extending from one river system to another, does not develop because the saturated interval of bedrock is relatively thin and the head differences required are not present.

\section{GROUND-WATER QUALITY}

Water samples were taken for chemical analyses from wells 460 and 458 at the close of the 24-hour pumping tests in February and March 1979. At that time the wells were open from about 44 to 100 feet and 150 to 203 feet, respectively. During August 1983, water samples were collected from 17 wells in the piezometer arrays of burial ground 5. These wells were constructed with open intervals of 5- to 13feet between depths of 6 feet and 203 feet.
All water samples were analyzed at ORNL for selected radionuclides (table 9). The 2 samples taken in 1979 and 15 of the 17 samples taken in 1983 were analyzed by the USGS for physical properties, principal ions, minor constituents, and trace metals (table 10). The samples taken from wells 464 and 476 in 1983 were analyzed at ORNL for trace metals. The dilutions necessary to reduce the tritium and strontium-90 concentrations, respectively, in those two samples to acceptable levels for trace-metal analysis by flame chromatography at the Geological Survey's laboratory would have jeopardized the integrity of the analyses. Although an analysis was made at the USGS Laboratory of the sample from well 470 , the results are not included in the tabulation because the data do not meet quality-control criteria.

All of the wells listed in table 10 derive their water from the Maryville Limestone, except well 464 which receives its water from the Nolichucky Shale, and well 469A which is recharged by the Rogersville Shale.

Analyses of water from wells $439,440,468$, and 472 , all less than 40 feet deep, reflect the chemical character of water in the regolith of this site. The dissolved solids concentration in water from three of these wells ranged from 360 to 570 $\mathrm{mg} / \mathrm{L}$ (milligrams per liter). The specific conductance of the fourth sample (well 468) implies a dissolved solids concentration of somewhat less than $360 \mathrm{mg} / \mathrm{L}$. The water is composed of high percentages of calcium and bicarbonate, and ranges in $\mathrm{pH}$ from slightly acidic to slightly basic. This is typical of ground water from shallow wells 
Table 10.--Principal-ion, minor constituent, and trace metal analyses of water samples from piezometers, burial ground 5 [ Analyses performed under supervision of N.M. Ferguson, Analytical Chemistry Division, Oak Ridge National Laboratory]

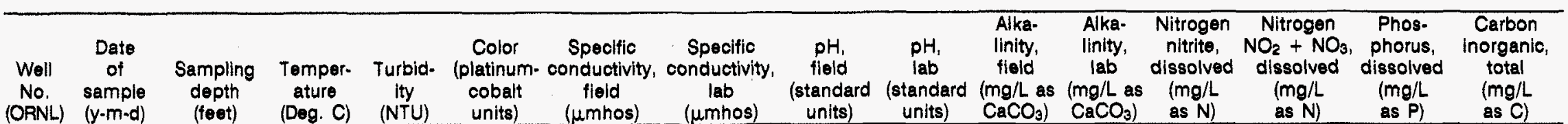

Regolith wells, less than 50 feet deep

$\begin{array}{rrrrrrr}439 & 83-08-26 & 24-34 & 16.5 & 3.0 & 3 & 87 \\ 440 & 83-08-23 & 26-36 & 21.0 & >1,000 & 1 & 885 \\ * 464 & 83-08-26 & 6-11 & 20.0 & -. & -. & 730 \\ 468 & 83-08-25 & 10-15 & 21.0 & 1,300 & 1 & 525 \\ 472 & 83-08-17 & 15-20 & 21.0 & 160 & 2 & 1,200 \\ * 476 & 83-08-26 & 25-30 & 17.0 & -. & -. & 890\end{array}$

$\begin{array}{rrr}875 & \ldots & 6.7 \\ 885 & 310 & 6.4 \\ 730 & -- & 6 . \\ 525 & 440 & 6.7 \\ 1,200 & -. & 6 . \\ 890 & -. & 7\end{array}$

Bedrock wells, open at about 100 feet below land surface

$\begin{array}{lllll}460 & 83-08-22 & 90-101 & 16.0 & 45 \\ 467 & 83-08-25 & 91-101 & 15.0 & 1.4 \\ 471 & 83-08-23 & 89-99 & 15.5 & 22 \\ 475 & 83-08-24 & 90-100 & 15.5 & 28\end{array}$

$\begin{array}{ll}4 & 93 \\ 2 & 310 \\ 6 & 210 \\ 1 & 340\end{array}$

Bedrock wells, open at about 150 feet below land surface

$\begin{array}{ccccccc}459 & 83-08-22 & 130-140 & 15.5 & 24 & 3 & 305 \\ 466 & 83-08-25 & 142-152 & 15.0 & 6.0 & 5 & 540\end{array}$

$\begin{array}{lllllll}466 & 83-08-25 & 142-152 & 15.0 & 6.0 & 5 & 540 \\ 474 & 83-08-24 & 142-151 & 15.5 & 8.3 & 2 & 700\end{array}$

Bedrock wells, open at about 200 feet below land surface

$\begin{array}{llllll}458 & 83-08-22 & 190-202 & 15.5 & 7.4\end{array}$

458 - $43-08-22-190-202-15.5$

16.5
15.5

$\begin{array}{rr}7.8 & 45 \\ 9.7 & 3\end{array}$

380
950

950
3,900

344
870

4,260

812
290
150

units)

$\left.\underset{\mathrm{CaCO}}{3})_{(\mathrm{CaCO}}\right)$ as $\left.\mathrm{N}\right)$

as N)

(m)

as C)

Bedrock well, open 44 to 100 feet below land surface

460A 79-02-15 44-100 15.0

Bedrock well, open 150 to 203 teet below land surface

19.0

-.

5

320

569

$\begin{array}{ll}6.7 & 7.2 \\ 6.4 & 7.1 \\ 6.6 & . . \\ 6.7 & 7.4 \\ 6.2 & 7.1 \\ 7.3 & . .\end{array}$

250

$\begin{array}{lll}420 & 378 & 0.030\end{array}$

360

315

050

7.4

650

$219<.010$

.010
.050

2.00

$-$.

$<.100$

-.

0.030

.020

$<.010$

. .15

85

60

40

48

$\begin{array}{rrrrrrrr}6.8 & 7.7 & 220 & 191 & .050 & <.100 & <.010 & 48 \\ 9.4 & 9.4 & 126 & 139 & <.010 & <.100 & <.010 & 29 \\ 9.3 & 8.7 & . . & 37 & .050 & <.100 & <.010 & 9.6 \\ 8.6 & 7.9 & 138 & 141 & <.010 & .830 & <.010 & 34\end{array}$

$\begin{array}{rrrrrrrrr}270 & 9.2 & 8.5 & 82 & 75 & .050 & <.100 & <.010 & 16 \\ 520 & 9.3 & 9.6 & 246 & 261 & <.010 & <.100 & <.010 & 56 \\ 610 & 10.6 & 10.5 & 245 & 254 & <.010 & <.100 & <.010 & 38\end{array}$

38

59

44

$\begin{array}{rrrrrrrr}10.2 & 10.1 & 200 & . . & 417 & .060 & <.100 & .040 \\ 11.8 & 11.9 & 1,010 & . . & .020 & <.100 & <.010 & 44\end{array}$


Table 10.--Principalion, minor constituent, and trace metal analyses of water samples from piezometers, burial ground 5--Continued

\begin{tabular}{|c|c|c|c|c|c|c|c|c|c|c|c|c|c|c|}
\hline $\begin{array}{l}\text { Well } \\
\text { No. } \\
\text { ORNL) }\end{array}$ & $\begin{array}{l}\text { Calclum, } \\
\text { dissolved } \\
\text { (mg/L } \\
\text { as Ca) }\end{array}$ & $\begin{array}{c}\text { Magnesium, } \\
\text { dissolved } \\
\text { (mg/L } \\
\text { as } \mathrm{Ma})\end{array}$ & $\begin{array}{l}\text { Sodium, } \\
\text { dissolved } \\
\text { (mg/L } \\
\text { as } \mathrm{Na} \text { ) }\end{array}$ & $\begin{array}{l}\text { Potassium, } \\
\text { dissolved } \\
\text { (mg/L } \\
\text { as K) }\end{array}$ & $\begin{array}{l}\text { Chloride, } \\
\text { dissolved } \\
(\mathrm{mg} / \mathrm{L} \\
\text { as Cl) }\end{array}$ & $\begin{array}{c}\text { Sulfate, } \\
\text { dissolved } \\
\text { (mg/L as } \\
\left.\mathrm{SO}_{4}\right)\end{array}$ & $\begin{array}{c}\text { Fluoride, } \\
\text { dissolved } \\
\text { (mg/L } \\
\text { as F) }\end{array}$ & $\begin{array}{c}\text { Silica, } \\
\text { dissolved } \\
\text { (mg/L as } \\
\left.\mathrm{SiO}_{2}\right)\end{array}$ & $\begin{array}{l}\text { Solids, } \\
\text { residue } \\
\text { at } 180^{\circ} \mathrm{C} \\
\text { dissolved } \\
(\mathrm{mg} / \mathrm{L})\end{array}$ & $\begin{array}{c}\text { Arsenic, } \\
\text { total } \\
(\mu g / L \\
\text { as As) }\end{array}$ & $\begin{array}{c}\text { Earium, } \\
\text { total } \\
\text { recoverable } \\
(\mu \mathrm{g} / \mathrm{L} \\
\text { as } \mathrm{Ba}) \\
\end{array}$ & $\begin{array}{c}\text { Cadmium, } \\
\text { total } \\
\text { recoverable } \\
(\mu \mathrm{g} / \mathrm{L} \\
\text { as Cd) } \\
\end{array}$ & $\begin{array}{l}\text { Chromium, } \\
\text { total } \\
\text { recoverable } \\
(\mu \mathrm{g} / \mathrm{L} \\
\text { as Cr) } \\
\end{array}$ & $\begin{array}{c}\text { Cobalt } \\
\text { total } \\
\text { recoverable } \\
\text { ( } \mu g / L \\
\text { as Co) } \\
\end{array}$ \\
\hline
\end{tabular}

Regolith wells, less than 50 feet deep

\begin{tabular}{|c|c|c|c|c|c|}
\hline $\begin{array}{l}439 \\
440\end{array}$ & $\begin{array}{l}150 \\
150\end{array}$ & $\begin{array}{l}15 \\
17\end{array}$ & $\begin{array}{l}26 \\
18\end{array}$ & $\begin{array}{l}0.12 \\
2.1\end{array}$ & $\begin{array}{l}22 \\
36\end{array}$ \\
\hline *464 & -- & -. & .• & $\ldots$ & -- \\
\hline $\begin{array}{l}468 \\
472\end{array}$ & $\begin{array}{r}86 \\
180\end{array}$ & $\begin{array}{l}11 \\
24\end{array}$ & $\begin{array}{c}7.8 \\
43\end{array}$ & $\begin{array}{l}1.3 \\
2.2\end{array}$ & ${ }_{32}^{2,2}$ \\
\hline${ }^{*} 476$ & -. & $\ldots$ & -. & $\because$ & .. \\
\hline
\end{tabular}

Bedrock wells, open at about 100 feet below land surface

\begin{tabular}{|c|c|c|c|c|c|c|c|c|c|c|c|c|c|}
\hline $\begin{array}{l}460 \\
467 \\
471 \\
475\end{array}$ & $\begin{array}{c}92 \\
2.3 \\
6.1 \\
12\end{array}$ & $\begin{array}{l}40 \\
1.2 \\
20^{.17}\end{array}$ & $\begin{array}{l}12 \\
60 \\
18 \\
20\end{array}$ & $\begin{array}{c}6.0 \\
4.2 \\
12 \\
4.7\end{array}$ & $\begin{array}{c}170 \\
1.5 \\
11 \\
1.8\end{array}$ & $\begin{array}{c}7.6 \\
8.2 \\
15 \\
22\end{array}$ & $\begin{array}{r}<.10 \\
.10 \\
.20 \\
<.10\end{array}$ & $\begin{array}{c}15 \\
5.1 \\
2.0 \\
2.3\end{array}$ & $\begin{array}{r}525 \\
160 \\
89 \\
164\end{array}$ & $\begin{array}{r}<1 \\
1 \\
<1 \\
1\end{array}$ & $\begin{array}{r}500 \\
100 \\
<100 \\
100\end{array}$ & $\begin{array}{l}1 \\
2 \\
1 \\
2\end{array}$ & $\begin{array}{r}10 \\
6 \\
9 \\
7\end{array}$ \\
\hline
\end{tabular}

is Bedrock wells, open at about 150 feet below land surface

\begin{tabular}{|c|c|c|c|c|c|c|c|c|c|c|c|c|c|c|}
\hline $\begin{array}{l}459 \\
466 \\
474\end{array}$ & $\begin{array}{c}15 \\
1.6 \\
.82\end{array}$ & $\begin{array}{r}13 \\
.52 \\
.08\end{array}$ & $\begin{array}{r}14 \\
120 \\
110\end{array}$ & $\begin{array}{c}11 \\
2.6 \\
13\end{array}$ & $\begin{array}{c}32 \\
1.8 \\
1.5\end{array}$ & $\begin{array}{l}23 \\
13 \\
15\end{array}$ & $\begin{array}{r}<.10 \\
.30 \\
.20\end{array}$ & $\begin{array}{l}13 \\
2.5 \\
5.1\end{array}$ & $\begin{array}{l}172 \\
292 \\
296\end{array}$ & $\begin{array}{l}1 \\
1 \\
1\end{array}$ & $\begin{array}{l}100 \\
100 \\
100\end{array}$ & $\begin{array}{r}<1 \\
2 \\
1\end{array}$ & $\begin{array}{l}2 \\
2 \\
5\end{array}$ & $\begin{array}{l}2 \\
1\end{array}$ \\
\hline
\end{tabular}

Bedrock wells, open at about 200 feet below land surface

$\begin{array}{lllllllllllrrrr}458 & 8.8 & 7.7 & 65 & 4.4 & 2.2 & 12 & .30 & 10 & 227 & 1 & 400 & <1 & 4 & 3 \\ 469 \mathrm{~A} & 1.1 & .07 & 190 & 7.1 & 2.1 & 30 & .20 & 10 & 499 & 1 & <100 & 1 & 23 & 2 \\ 473 & 110 & <.10 & 300 & 44 & 3.4 & 46 & .90 & 3.0 & 1,040 & 1 & 300 & 1 & 8 & 1\end{array}$

Bedrock well, open 44 to 100 feet below land surface

$\begin{array}{lllll}460 \mathrm{~A} & 82 & 21 & 8.8 & 2.8\end{array}$

1410

$0.0 \quad 24$

337

$0 \quad 300$

Bedrock well, open 150 to 203 feet below land surface
458B
23
18
$17 \quad 5.7$

$7.6 \quad 15$

.1

18

182

2

300 
Table 10.--Principalion, minor constituent, and trace metal analyses of water samples from piezometers, burial ground 5--Continued

\begin{tabular}{|c|c|c|c|c|c|c|c|c|c|c|c|c|c|}
\hline $\begin{array}{l}\text { Well } \\
\text { No. } \\
\text { ORNL }\end{array}$ & $\begin{array}{r}\text { Co } \\
t \\
\text { reco } \\
\text { as }\end{array}$ & $\begin{array}{c}\text { Iron, } \\
\text { suspended } \\
\text { recoverabie } \\
\text { ( } \mu \mathrm{g} / \mathrm{L} \\
\text { as Fe) }\end{array}$ & $\begin{array}{c}\text { Iron, } \\
\text { total } \\
\text { recoverable } \\
(\mu \mathrm{g} / \mathrm{L} \\
\text { \&s } \mathrm{Fe})\end{array}$ & $\begin{array}{l}\text { Iron, } \\
\text { dissolve } \\
(\mu \mathrm{g} / \mathrm{L} \\
\text { as } \mathrm{Fe})\end{array}$ & $\begin{array}{c}\text { Lead, } \\
\text { total } \\
\text { recoverable } \\
\text { ( } \mu \mathrm{g} / \mathrm{L} \\
a s \mathrm{~Pb})\end{array}$ & $\begin{array}{c}\text { Manganese, } \\
\text { suspended } \\
\text { recoverable } \\
(\mu g / L \\
\text { as Mn) }\end{array}$ & $\begin{array}{c}\text { Manganese, } \\
\text { total } \\
\text { recoverable } \\
\text { ( } \mu \mathrm{g} / \mathrm{L} \\
\text { as Mn) }\end{array}$ & $\begin{array}{r}\text { Mangan } \\
\text { dissolv } \\
(\mu g / L \\
\text { as Mn }\end{array}$ & diss & $\begin{array}{l}\text { Strontium, } \\
\text { dissolved } \\
(\mu \mathrm{g} / \mathrm{L}\end{array}$ & $\begin{array}{c}\text { Zinc, } \\
\text { total } \\
\text { recoverable } \\
(\mu \mathrm{g} / \mathrm{L} \\
\text { as } \mathrm{Zn})\end{array}$ & & $\begin{array}{l}\text { ary, } \\
\text { rable } \\
\text { ra } \\
\text { dg) }\end{array}$ \\
\hline
\end{tabular}

Regolith wells, less than 50 feet deep

$\begin{array}{rrrrrrrrrrrrrrr}439 & 18 & \ldots & 12,000 & 78 & 30 & 150 & 330 & 180 & 18 & 240 & 30 & 300 & 30 & <.1 \\ 440 & 360 & 390,000 & 390,000 & 450 & 500 & 11,000 & 11,000 & 270 & 21 & 270 & 1,300 & 400 & 8 & 700 \\ * 464 & 10 & -. & 300 & -. & 40 & -. & 730 & 500 & 44 & 700 & 120 & 260 & 10 & <.2 \\ 468 & 47 & 14,000 & 16,000 & 2,200 & 36 & 40 & 110 & 68 & 4 & 190 & 130 & <100 & 16 & <.1 \\ 472 & 25 & 7,000 & 33,000 & 26,000 & 46 & 0 & 1,400 & 1,400 & 50 & 400 & 200 & 100 & 140 & <.1 \\ * 476 & 20 & -. & 22,000 & 9,600 & 480 & -. & 14,000 & 13,000 & 35 & 700 & 200 & 40 & 30 & <.2\end{array}$

Bedrock wells, open at about 100 feet below land surface

\begin{tabular}{|c|c|c|c|c|c|c|c|c|c|c|c|c|c|c|}
\hline $\begin{array}{l}460 \\
467 \\
471 \\
475\end{array}$ & $\begin{array}{r}3 \\
11 \\
13 \\
8\end{array}$ & $\begin{array}{r}7,800 \\
4,200 \\
18,000 \\
11,000\end{array}$ & $\begin{array}{r}13,000 \\
4,200 \\
18,000 \\
11,000\end{array}$ & $\begin{array}{r}5,200 \\
13 \\
10 \\
5\end{array}$ & $\begin{array}{l}11 \\
52 \\
56 \\
30\end{array}$ & $\begin{array}{r}0 \\
\ddot{-} \\
100\end{array}$ & $\begin{array}{r}150 \\
40 \\
140 \\
110\end{array}$ & $\begin{array}{l}160 \\
<1 \\
<1 \\
14\end{array}$ & $\begin{array}{l}2 \\
1 \\
1 \\
1\end{array}$ & $\begin{array}{r}900 \\
160 \\
270 \\
1,300\end{array}$ & $\begin{array}{r}50 \\
420 \\
190 \\
120\end{array}$ & $\begin{array}{l}100 \\
100 \\
100 \\
100\end{array}$ & $\begin{array}{l}29 \\
70 \\
50 \\
28\end{array}$ & $\begin{array}{r}.2 \\
<.1 \\
<.1 \\
<.1\end{array}$ \\
\hline
\end{tabular}

is Bedrock wells, open at about 150 feet below land surface

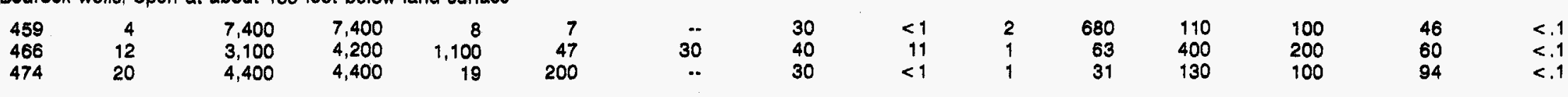

Bedrock wells, open at about 200 feet below land surface

$\begin{array}{lrlllllllrrrrrr}458 & 3 & 3,800 & 3,900 & 150 & 5 & 1 & 20 & 19 & 1 & 990 & 50 & <100 & 39 & .1 \\ 469 A & 15 & 6,200 & 6,200 & 28 & 50 & -. & 50 & <1 & 1 & 33 & 160 & <100 & 82 & .1 \\ 473 & 19 & 1,500 & 1,600 & 100 & 96 & -. & 30 & <10 & 4 & 1,000 & 70 & 1,100 & 380 & <.1\end{array}$

Bedrock well, open 44 to 100 teet below land surface

$460 \mathrm{~A} \quad 9 \quad 3,200 \quad 20$

0

$+\cdots \quad 60$

Bedrock well, open 150 to 203 feet below land surface

458B 5

430

10

9

60

10

$\cdots$

.. 250 
and springs in the Conasauga Group of eastern Tennessee (DeBuchananne and Richardson, 1956).

Principal ion data are plotted on a trilinear diagram (fig. 34) to show the difference in composition between water from the regolith and that from the bedrock. The close grouping together in the diamond's left corner of the four points representing the regolith wells shows a uniformity in the major constituents of water from the regolith. It also shows that water in this part of the aquifer is rich in calcium-magnesium/ carbonate-bicarbonate.

Water from all of the regolith wells was enriched in dissolved manganese and nickel relative to water from the bedrock wells. Relatively high concentrations of strontium, zinc, suspended iron, dissolved iron, barium, chromium, copper, and lead were found in water from some of the regolith wells. While the presence of many of these metals and trace elements in ground water results partly from slight dissolution of the aquifer skeleton as water passes through it, it is highly probable that much of the mineralization in this area is due to the leaching of buried waste as infiltrating water passes through the trenches and is assimilated into the ground-water reservoir.

The other analyses in table 10 represent water from the bedrock. Analytical results of the well 4.58 sample in 1979 show a different principal ion composition than that of 1983 . This probably is due to the presence of drilling water in the aquifer, even after slow pumping for 24 hours. The two analyses of water from well 460 four years apart are generally similar, although that of 1979 might also have been influenced to some extent by drilling water.

Dissolved-solids concentrations of samples taken in 1983 show that the water from most of the bedrock wells has relatively little mineralization. The average concentrations were $222 \mathrm{mg} / \mathrm{L}$ in water from the 100 -foot piezometers, 255 $\mathrm{mg} / \mathrm{L}$ in water from the 150 -foot piezometers, and $357 \mathrm{mg} / \mathrm{L}$ in water from the 200 -foot piezometers.

Although the mineralization is low, water in the bedrock is composed of high percentages of sodium and bicarbonate. The concentration of calcium, the predominant cation in the regolith water usually is much less than that of sodium, the predominant cation in the bedrock water. Magnesium content also tends to be less and potassium content tends to be greater, but the differences are not as pronounced as the calcium-sodium difference. The trilinear diagram (fig. 34) shows the difference in water composition between the regolith and at three horizons in the bedrock. Points for three 100-foot wells and one 150-foot well are scattered across the diamond, indicative of water having a mixed composition. Points for one 100-foot well, two 150 -foot wells, and three 200 -foot wells are clustered in the lower corner of the diamond, indicative of high sodium-potassium/carbonate-bicarbonate content of water. The diagram reveals a definite trend for the principal cationic composition of ground water below the site to change 
EXPLANATION

COMPOSITIONAL RELATIONSHIP OF PRINCIPAL

IONS IN WATER FROM WELLS OPEN TO:

Regolith, at depths of

$\odot$ less than 40 feet

Bedrock, at depths of

(-) 90-100 feet

140-150 feet

$\triangle$ 190-200 feet

Number identifies well

in table 10

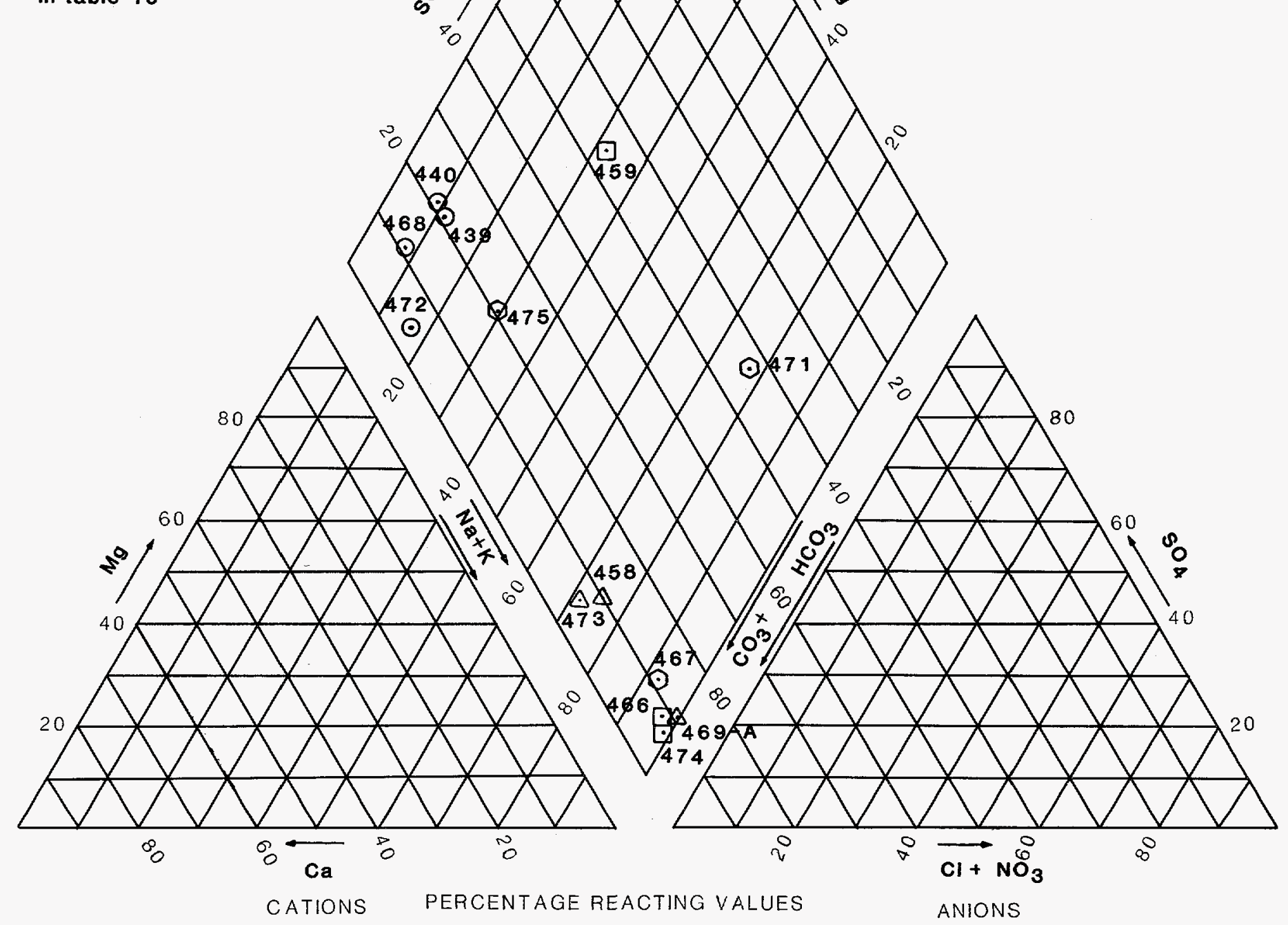

Note: For each sample analysis, the percentage of cations and anions are plotted in the two triangles and the points are projected to the diamond. The location of the points within the diamond indicate the principal-ion composition (Piper, 1944).

Figure 34.--Trilinear diagram showing principal-ion composition of ground water at four depth intervals, burial ground 5. 
with increasing depth from calcium in the regolith to sodium in the deeper part of the aquifer.

There is also a tendency indicated for the $\mathrm{pH}$ of water to increase with depth. The field $\mathrm{pH}$ of water from seven wells was greater than 9 ; that of three wells 150 to 200 feet deep was greater than 10 .

Water from a few of the bedrock wells had relatively high concentrations of strontium, dissolved iron, aluminum, and lithium. The variety and amount of metals in water from bedrock is less than that of water from the regolith because high $\mathrm{pH}$ inhibits the solubility of many of the metals.

Analyses of water from two bedrock wells differ from the trend. Well 460 , open to the aquifer from 90 to 100 feet, has water that in principal ion composition, trace metal concentration, $\mathrm{pH}$, and tritium concentration more closely resemble that of the regolith than that of the bedrock. This well apparently receives fairly direct recharge from the regolith. This suggests that its open interval intercepts or lies close to a fracture or fault through which water is readily transmitted. Well 473 has water that is highly mineralized for this area. The water may be of connate origin and coming from greater depth via a concealed fault. Haase and others (1984, p. 33-34) reported finding a $\mathrm{Na}-\mathrm{K}-\mathrm{Ca}-\mathrm{C} 1$ brine underlying fresh water in wells as much as 1,500 feet deep in a nearby area, and suggested its source is the lower Rome Formation or the underlying Chickamauga Limestone (fig. 3). It is also possible that some of the constituents in the water may represent water of dehydration from the grout used to set the casing. Less likely pos- sibilities are that the well is receiving water that bleeds from the grout sheets injected at the hydrofracture plant, "relic water" migrating from the hydrofracture-test site to the east, or fluids from waste ponds in the reactor area of Melton Valley. The low hydraulic conductivity and depth of the open zone, the relatively long, slow flow path indicated in section A-A' of figure 32, and relative lack of tritium, despite the well's location in an area where thousands of curies of tritium have been buried, do not favor an interpretation of water tainted by the burial of waste at shallow depth.

The principal-ion data reflect depth of circulation and support the conceptual model of flow offered earlier. Sodium and potassium are among the most soluble constituents of rock, and are removed early in the rock-weathering process. The increasing prominence of these ions in water as depth increases indicates that relatively small amounts of water are circulating at depth. Consequently, the sodium and potassium in solution in the bedrock part of the aquifer have not been flushed out. In contrast, the concentration of these ions in regolith water is comparatively low because much of the sodium and potassium have already been leached and discharged from the system and, to perhaps some minor degree, the higher effective porosity of the regolith affords a slightly greater dilution factor. It is possible too that some fraction of the sodium ions in solution in the regolith have been exchanged for calcium ions on the mineral faces. The change in principal ion composition between 40 and 100 feet suggests that most of the water flows through the system at some depth less than 100 feet. 


\section{SURFACE-WATER HYDROLOGY}

\section{DRAINAGE CHARACTERISTICS}

The Whiteoak Creek drainage basin covers 6.53 square miles at its mouth on the Clinch River. Altitudes in the basin range from 741 feet at the mouth to 1,356 feet above sea level on Copper Ridge. Whiteoak Lake, an impounded segment of Whiteoak Creek, is located about 0.6 mile above the mouth of the creek.

Continuous-record stations have been operated at three locations on Whiteoak Creek and at one location on Melton Branch. The stations and their periods of record are, in downstream order, Whiteoak Creek at ORNL, 1950-55; Whiteoak Creek below ORNL, 195053, 1955-64, and 1978-81; Melton Branch, 195564 and 1977-80; and Whiteoak Creek at Whiteoak Dam, 1953-55, 1960-64, and 1977-79. These stations are also known as monitoring stations $2,3,4$, and 5, respectively, in the ORNL monitoring network. Station characteristics and flow data are listed in table 11 and the station locations are shown on figure 35 .

Streamflow in the Whiteoak Creek basin consists of overland runoff from rainfall, groundwater discharge during base flow, and wastewater discharge from ORNL. An estimated 45 percent of the annual rainfall reaches the streams as overland runoff and as base flow discharge from the aquifers (McMaster, 1967, p. N14). The wastewater is treated, process water that is imported to the Whiteoak Creek drainage basin. McMaster (1967, p. N5) reported that wastewater discharge amounts to an average of about 3.5 $\mathrm{ft}^{3} / \mathrm{s}$. During dry periods, wastewater is the principal component of flow.

Flow duration curves describe the sustainability of flow. A flow-duration curve is a cumulative frequency curve showing the percentage of time that a specific mean daily discharge was equaled or exceeded during the period of record for that station. Curves were computed for the four continuous-record stations in the Whiteoak Creek basin to show variations in yield (fig. 36). On these, streamflow is expressed as cubic feet per second per square mile of drainage area to compare differences in discharge that are unrelated to differences in drainage areas. The interpretations that follow are tentative, owing to the short periods of record.

The flow-duration curves are similar for all four stations during periods of high flow when overland runoff is the predominant component of flow. Curves separate to show variations in streamflow during periods of base flow. Base flow at the stations depends on local geology and aquifer characteristics, and percent of flow composed of wastewater from ORNL.

The effects of local geology and aquifer characteristics are illustrated in the duration curves for Melton Branch (station 4) and Whiteoak Creek at ORNL (station 2). The Conasauga Group underlies the area drained by Melton Branch at station 4. Base flow from this aquifer occurs at a very low rate. The Knox Group and Chickamauga Limestone underlie the area drained by Whiteoak Creek at station 2. The higher permeability of and greater amount of water in storage in these formations enable this 


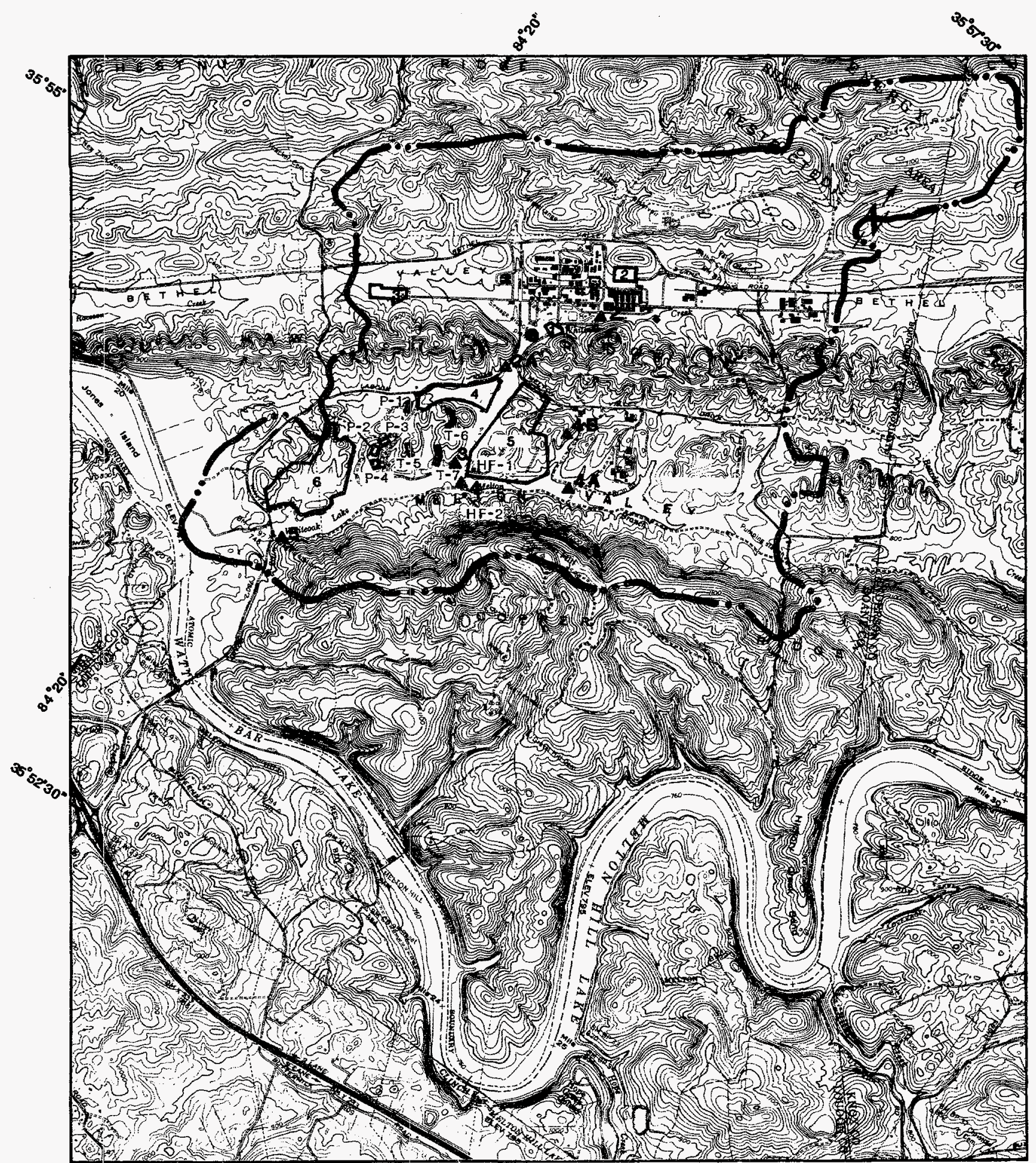

Bas trom USGS-TVA Bethel Valley, Lenoir Chy, and Lovell, $t: 24,000,1968$

EXPLANATION

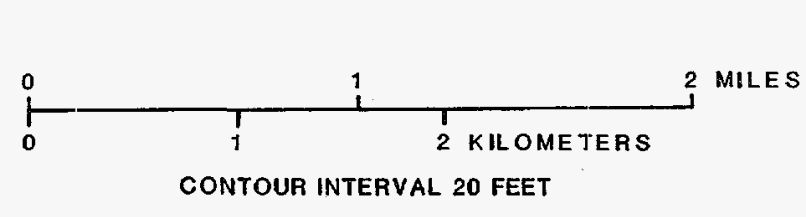

NATIONAL GEODETIC VERTICAL DATUM OF 1929

Figure 35.--Location of gaging stations and monitoring stations in the Whiteoak Creek drainage basin. 


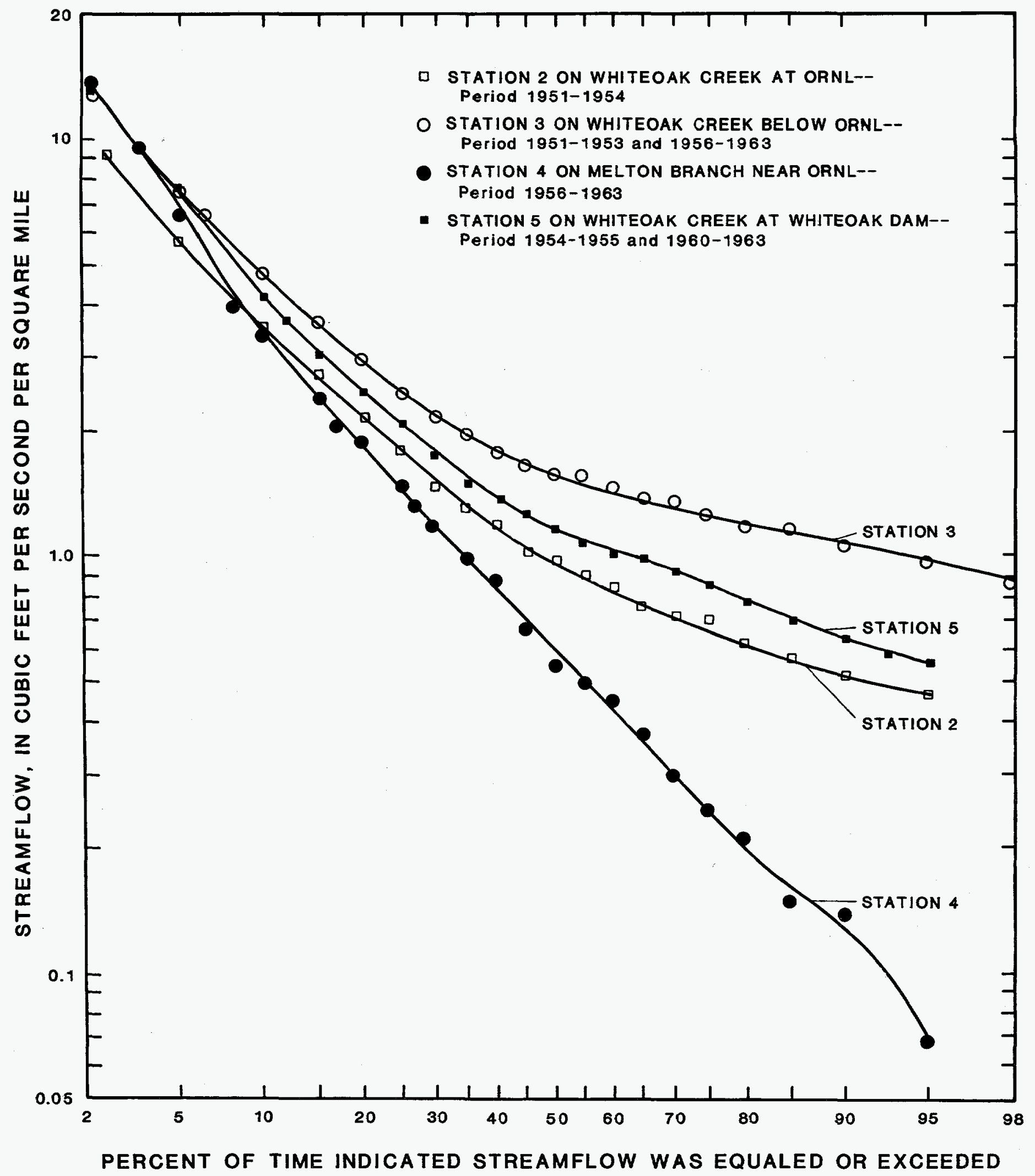

Figure 36.--Streamflow-duration curves for continuous-record stations in the Whiteoak Creek basin. 
Table 11.--Station characteristics and flow data of the gaging stations at Whiteoak Creek and Melton Branch, through 1981

[Data sources: U.S. Geological Survey, 1964, 1971; unpublished data in the files of the UI.S. Geological Survey. Note: Map numbers refer to figure 35]

\begin{tabular}{|c|c|c|c|c|c|c|c|}
\hline $\begin{array}{l}\text { USGS } \\
\text { gaging } \\
\text { station } \\
\text { number }\end{array}$ & $\begin{array}{c}\text { ORNL } \\
\text { monitoring } \\
\text { station no. and } \\
\text { map no. }\end{array}$ & $\begin{array}{c}\text { Drainage } \\
\text { area, in } \\
\text { square } \\
\text { miles }\end{array}$ & Gage & $\begin{array}{l}\text { Period } \\
\text { of } \\
\text { record }\end{array}$ & Dischar & in cubic feet & per second \\
\hline 035650 & 2 & 2.08 & $\begin{array}{l}\text { Water-stage } \\
\text { recorder. }\end{array}$ & $1950-55$ & 3.9 & 616 & 0.7 \\
\hline 035370 & 3 & 3.62 & $\begin{array}{l}\text { Water-stage } \\
\text { recorder and } \\
\text { Cipolletti weir. }\end{array}$ & $\begin{array}{c}1950-53 \\
1955-64 \\
1978-81\end{array}$ & 9.6 & 642 & .9 \\
\hline 035375 & 4 & 1.48 & $\begin{array}{l}\text { Water-stage } \\
\text { recorder and } \\
\text { V-notch sharp- } \\
\text { crested weir. }\end{array}$ & $\begin{array}{l}1955-64 \\
1977-80\end{array}$ & 2.5 & 242 & 0 \\
\hline 035380 & 5 & 6.01 & $\begin{array}{l}\text { Water-stage } \\
\text { recorder. }\end{array}$ & $\begin{array}{l}1953-55 \\
1960-64 \\
1977-79\end{array}$ & 13.5 & 669 & 0 \\
\hline
\end{tabular}

part of the drainage basin to sustain base flow at a larger rate. Consequently, the duration curve for Melton Branch (station 4) is much steeper during base flow than the curve for Whiteoak Creek at ORNL (station 2).

Duration curves for the three stations on Whiteoak Creek show the effect of wastewater discharge. Whiteoak Creek at ORNL (station 2) has base flow derived from ground water. Streamflow at this station equals or exceeds 1.0 $\left(\mathrm{ft}^{3} / \mathrm{s}\right) / \mathrm{mi}^{2}$ for 50 percent (P50) of the time. Streamflow at Whiteoak Creek below ORNL (station 3) is more than $1.6\left(\mathrm{ft}^{3} / \mathrm{s}\right) / \mathrm{mi}^{2}$ at P50. The increase in flow represents the amount of wastewater from ORNL entering Whiteoak Creek between these stations. The relative difference is even more pronounced at low flow. Discharge in Whiteoak Creek at ORNL is about $0.62\left(\mathrm{ft}^{3} / \mathrm{s}\right) / \mathrm{mi}^{2}$ at $\mathrm{P} 80$, whereas discharge in Whiteoak Creek below ORNL is about 1.2 $\left(\mathrm{ft}^{3} / \mathrm{s}\right) / \mathrm{mi}^{2}$ at $\mathrm{P} 80$.

The duration curve for station 5 in Melton Valley more closely resembles the curves of stations 2 and 3, both on Whiteoak Creek, than that of station 4 on Melton Branch. This reflects the combined effects of local geology upon base flow and the discharge of waste water to the stream. 
A review of the 1977-1979 record for several 1- to 2-week periods when discharge was within the confines of the weirs and the recorders were functioning properly indicated that discharge at station 5 (Whiteoak Dam) was 10 to 20 percent less than the combined flow past stations 3 and 4. The difference could not be accounted for by transpiration, evaporation from Whiteoak Lake, or leakage through the lake bottom. It appears to result from an error in the rating curve developed in 1962 by the USGS for station 5, and is greatest during periods of low discharge (B. J. Frederick, written commun., 1978). An adjustment for this would result in a slight upward shift in the curve for station 5 at low discharge rates. In addition, inasmuch as the accuracy of flow measurements at the monitoring stations influences the accuracy of the monitoring data, it is likely that the discharge of radionuclides to the Clinch River was greater than that reported from approximately 1962 until late-1979 when the gate at the dam was lowered.

\section{RADIONUCLIDE DISCHARGE}

There are many sources of the contaminants in the Whiteoak Creek drainage system. Point sources that routinely have discharged contaminated fluids include the wastewater treatment plant, reactor facilities, sewage-treatment plant, and laundry. Various plant operations also have released waste fluids to the creek by accident, and during storm events have jettisoned fluids to take advantage of the dilution afforded by large flow-volume. Indirect sources include the ILW pit system, the burial grounds, tank farms, and underground pipe lines that have broken.

Studies of the Whiteoak Creek drainage system provide evidence that this drainage is the receiving stream for contaminants transported from the burial grounds as well as other areas. In 1959-1960, Lomenick and Cowser (1961, p. 2830) attempted to quantify contaminant discharge to Whiteoak Creek from burial ground 4, but were unable to do so because of the discharge of much larger quantities of radionuclides at upstream sources. Later that decade, efforts were made to find the source of the several thousand curies of tritium being discharged annually to the Clinch River. Sampling of wells, seeps, and the tributary drainages showed that large quantities of this radionuclide were being released from burial ground 5 (T.F. Lomenick, ORNL, oral commun., 1974). Duguid (1975, p. 42; 1976, p. 20), using an indirect approach, estimated that the discharge of ${ }^{90} \mathrm{Sr}$ from burial ground 4 to Whiteoak Creek ranged from about 1.2 to 5.2 curies annually during the years 1971 to 1975 , and its variability from year to year was directly related to precipitation. This correlation suggests transport both in ground water and overland flow from trench spillage. Steuber and others (1978, p. 20) found that the discharge of ${ }^{90} \mathrm{Sr}$ from burial ground 5 to Melton Branch during 1978 was about 0.45 curies, and was fairly constant from year to year regardless of variability in precipitation. This suggests that the principal mode of transport is dissolution in ground water and discharge into Melton Branch rather than the flushing of trenches by infiltration. "Grab samples" of water in some of the small drainages in or bounding the disposal sites 
were taken during extended dry periods in 1977 1978 as part of this study. Although grab sampling is only a cursory type of investigation, the water in the drainages during dry periods reflects aquifer discharge. The analytical results are given in table 12 , and show that ${ }^{3} \mathrm{H}$ and ${ }^{90} \mathrm{Sr}$ were the principal contaminants identified. Cerling and Spalding (1982) examined the relations between streambed gravels in the Whiteoak Creek watershed and ${ }^{60} \mathrm{Co},{ }^{90} \mathrm{Sr}$, and ${ }^{137} \mathrm{Cs}$ sorbed to the gravels. They found that the gravels in the drainage on the south side of burial ground 4 had the highest sustained concentration of ${ }^{90} \mathrm{Sr}$ of any drainage in the watershed; those gravels also had minor concentrations of ${ }^{60} \mathrm{Co}$ and ${ }^{137} \mathrm{Cs}$. The concentration of ${ }^{90} \mathrm{Sr}$ and ${ }^{137} \mathrm{Cs}$ on gravels in Melton Branch gradually increased as that stream passed the south side of burial ground 5 . They interpreted this as an indicator of contamination emanating from a diffuse source, and suggested the increase is due to contaminated ground water from burial ground 5 entering Melton Branch at numerous points. On gravels from the principal drainage within burial ground 6 , they found a constant concentration of ${ }^{90} \mathrm{Sr}$ over a 200-meter stretch. This was attributed to discharge from a ground-water seep into a drainage that has no tributaries before discharging into Whiteoak Lake.

The results of these studies support the interpretation that the local drainage system is recipient of leachate from the buried waste. Studies, however, have not been made to confirm that this drainage system is the sole initial recipient of contaminants from the Melton Valley burial grounds as indicated by interpretation of the ground-water data, discussed in the preceeding sections of this report.

\section{MONITORING}

Whiteoak Creek is literally the terminal phase of ORNL's waste-disposal system. Consequently, most of the historical monitoring efforts have focused upon it. The primary objective of monitoring has been to meet the Code of Federal Regulations' requirement that the average annual concentration of radionuclides in effluent discharged to off-site areas be maintained within established limits. This has been done by monitoring the creek at Whiteoak Dam (station 5, figure 35) where the discharge enters an estuary of the Watts Bar Reservoir. Monitoring at this point has been more or less continuous since 1943 (see Webster, 1976, p. 60, for details). Additional monitoring stations were established at upstream locations during the 1940's and 1950's, but only station 1 at the waste-water treatment plant, a major contributor to the contaminant load of the creek during the early years of operation, was installed to monitor a point source of contamination. Station 2 was installed to determine the total load from areas upstream of station 1, and stations 3 and 4, located near the confluence of Whiteoak Creek with Melton Branch, were installed to determine which valley was the source area for an unaccountable amount of strontium-90 found at Whiteoak Dam. More recently, station $2 \mathrm{~A}$ was installed on Whiteoak Creek upstream from burial ground 4, and stations 4A and 4B were installed on Melton Branch and one of its tributaries upstream from burial ground 5, in support of the burial-ground studies being conducted by ORNL and USGS personnel. Thus, with a few exceptions, the thrust of monitoring has been oriented historically on the final waste product leaving ORNL rather than on the point sources of contamination. 
Table 12.--Concentrations of selected radionuclides in small drainages of the burial grounds during extended dry periods [NA, analysis not made for this isotope. Analyses performed by Analytical Chemistry Division, Oak Ridge National Laboratory]

\begin{tabular}{|c|c|c|c|c|c|c|}
\hline \multirow[b]{2}{*}{ Sampling site } & \multirow[b]{2}{*}{$\begin{array}{l}\text { Date of } \\
\text { sample }\end{array}$} & \multicolumn{5}{|c|}{ Analytical results in $\mathrm{Bg} / \mathrm{L}$} \\
\hline & & $\begin{array}{l}\text { Total } \\
\text { alpha }\end{array}$ & ${ }^{3} \mathrm{H}$ & ${ }^{90} \mathrm{Sr}$ & ${ }^{60} \mathrm{Co}$ & ${ }^{137} \mathrm{Cs}$ \\
\hline $\begin{array}{l}\text { Drainage on south side } \\
\text { of burial ground } 4, \\
\text { about } 100 \text { feet down- } \\
\text { stream from well } 186 .\end{array}$ & $6-30-78$ & NA & $3.83 \times 10^{4}$ & $1.95 \pm 0.03 \times 10^{2}$ & $\leq 0.5$ & $\leq 0.8$ \\
\hline $\begin{array}{l}\text { Drainage between east } \\
\text { and west lobes of burial } \\
\text { ground } 5 \text {, at culvert } \\
\text { west of well } 427 \text {. }\end{array}$ & $7-10-77$ & $\leq 5$ & $1.03 \times 10^{6}$ & $9.12 \times 10^{1}$ & $\leq 1 \times 10^{-7}$ & NA \\
\hline Same as above & & & $60 n \times 10^{5}$ & $65+02 \times 10^{1}$ & & \\
\hline $\begin{array}{l}\text { Drainage on west side of } \\
\text { burial ground } 5 \text {, near } \\
\text { well } 134 \text {. }\end{array}$ & $6-30-78$ & NA & $5.08 \times 10^{3}$ & $1.83 \pm 0.3$ & $\begin{array}{l}\leq 0.5 \\
8.5 \pm 0.8\end{array}$ & $\begin{array}{l}\leq 0.8 \\
\leq 0.8\end{array}$ \\
\hline Same as above & $7-10-77$ & $\leq 0.3$ & $4.55 \times 10^{5}$ & $1.97 \times 10^{2}$ & $\leq 8 \times 10^{-8}$ & NA \\
\hline $\begin{array}{l}\text { Drainage in burial ground } \\
6, \text { west of well } 279 \text {. }\end{array}$ & $6-30-78$ & NA & $1.53 \times 10^{5}$ & $6.5 \pm 0.2 \times 10^{1}$ & $\leq 0.5$ & $\leq 0.8$ \\
\hline
\end{tabular}


The burial grounds have not been the subject of a routine monitoring program until recently because their hazard potential compared to the other sources of contamination in this drainage basin has been regarded as minimal. During the past several years improvements at various plant facilities have resulted in a significant reduction of their discharge of radionuclides to Whiteoak Creek, and consequently of the creek's discharge of radionuclides to the Clinch River. As the amount from these other sources has declined, the amount from the burial grounds relative to the total load has increased. The burial grounds now represent one of principal scurces of strontium-90 and tritium in the discharge at Whiteoak Dam.

\section{SUMMARY AND CONCLUSIONS}

Several thousand cubic feet of waste materials contaminated by an unknown amount of radioactivity have been interred in each of the three Melton Valley burial grounds. At burial ground 4, virtually all of the trenches extend below the water table during winter and early spring. Many contain water throughout the year, and a small number of trenches in the central part of the site and in the low terrace on the east boundary overflow seasonally. At burial ground 5 , trenches in the topographically lower areas along the southern, southeastern, and eastern perimeter penetrate the water table during most of the year. Several trenches in the low areas of the east lobe overflow after extended periods of rain. At burial ground 6 , trenches in limited areas extend below the water table, but none are known to spill their fluid.
Infiltration that intermittently passes through the waste, and ground water in prolonged contact with it, promotes the leaching of both stable and radioactive ions from the buried material. The contaminants in the leachate have migrated beyond the trench areas at each site. Two principal modes of transport are recognized. One is by trench spillage and subsequent overland flow; the other is by transport in ground water through the geologic materials surrounding the trenches and underlying the disposal sites.

Five of the six formations of the Conasauga Group, a complex sequence of fine-grained, clastic-rich units alternating with carbonate-rich units, underlie the waste-disposal areas in Melton Valley. The formations are structurally complex. The openings developed in the regolith by weathering processes, and those created in the underlying bedrock by regional faulting and related breakage, provide a network of low permeability passageways for the flow of ground water and contaminants in that water. The heterogeneity of the lithology, the variability of the structural features, and in some areas the excavation of trenches below the present water table, provide an anisotropic medium in which the ground-water system functions. The degree of anisotropy is variable, both laterally and vertically. The resulting ground-water flow patterns are complex, but are definable in general terms.

A conceptual model of ground-water flow through the entire column of the saturated Conasauga Group shows three zones:

(1) A zone in the regolith at and immediately below the water table where the largest 
vector of flow trends in the same direction as the water-table gradient inferred from water-level data of shallow wells. A much smaller vector of flow corresponds to the direction of bedding (formation strike). The latter vector is nonexistent where the beds have weathered to an entirely porous material.

(2) In some areas, a transitional zone grading rapidly from regolith into bedrock where inferred water-table gradient and bedding vectors of flow have significant magnitude relative to each other.

(3) A zone comprising the water-bearing section of the bedrock where the largest vector of flow is oriented in the direction of formation strike, reflecting flow between bedding planes, and a smaller vector of flow is oriented across the beds, reflecting flow through openings within the beds.

Where gradient and strike are virtually the same, the flow vector across the beds is very small or nonexistent. Locally, gradients within resistant beds and structural features may control the direction of flow in any of the three zones.

Most of the recharge received by the system flows through the regolith only. Three reasons support this conclusion:

(1) The hydraulic conductivity of the regolith is greater than that of the bedrock; therefore, the bedrock's ability to accept and transmit recharge is less, and that ability decreases as depth increases.
(2) The saturated boundary of the bedrock is fixed; therefore, in order for it to accept a particle of water as recharge, it must eliminate a particle of water as discharge, which is comparatively more difficult for it to do. In contrast, the upper saturated boundary (the water table) of the regolith is flexible. The regolith can accept recharge without simultaneous discharge by a rise in the water table. With the regolith's greater hydraulic conductivity, that recharge can be passed on and eliminated more readily.

(3) The chemical and radiochemical data indicate that most recharge flows through the regolith.

Because the water-table gradient is thought to be the dominant factor that controls the direction of ground-water flow in the regolith, water-table contour maps can be helpful for predicting the general direction of lateral flow and areas of discharge. Even though the system is anisotropic, the degree of anisotropy probably is not great enough to impair prediction of general discharge areas. By use of this method, ground water in the eastern fourth of burial ground 4 is projected to discharge directly to the abandoned channels of Whiteoak Creek and possibly to the creek itself. Ground water in the remainder of the site discharges to the southboundary tributary. The upstream half of this short drainage receives discharge from the entire west half of burial ground 4 . Ground water in the regolith of burial ground 5 discharges to the drainages that arise within the site boundary, the unnamed tributary to the east, Melton Branch, and Whiteoak Creek. Discharge appears to be generally diffuse along each stream's length. 
Ground water in the regolith of burial ground 6 also discharges to the streams that arise within it, the drainage between that site and the ILW disposal area, and directly to Whiteoak Lake. Discharge occurs along the lengths of the drainages and the lake bottom.

Fotentiometric data for the 5-south area of burial ground 5 indicate that ground water in the regolith provides recharge to the bedrock underlying all of the site except in the topographically low areas near the drainages. In these areas, ground water in the bedrock moves upward into the regolith and discharges to the local drainages. The potentiometric-head relations indicate that all ground-water discharge from this site, whether from the regolith or the bedrock, is into the Whiteoak Creek drainage system. By projecting the potentiometric-head relations of burial ground 5 to other areas in Melton Valley, it is inferred that the regolith of burial ground 4 might have potential to supply recharge to the shallow bedrock only along the higher, western end. Water in the shallow bedrock is thought to flow more or less laterally below the site to discharge into either Whiteoak Creek, the flood plain, or the south-boundary tributary. At burial ground 6, the upland areas provide recharge to the bedrock underlying that site. Discharge is projected to occur along the local drainages within or bordering the site. Thus, at all three sites, ground-water in the bedrock is thought to discharge into the Whiteoak Creek drainage network. The relatively shallow depth of groundwater circulation (estimated to be about 200 to 250 feet) and the hydraulic potentials present do not favor the development of deep interbasin flow through bedrock from one river system to another.
Apparent hydraulic conductivities of the regolith as measured by slug tests of wells ranged from about $2.9 \times 10^{-3}$ to $6.7 \mathrm{ft} /$ day. The low values are associated with the regolith derived from siltstone and mudstone; the high values are associated with regolith derived from carbonate and shaley carbonate rock. The variability between the two extremes reflects the heterogeneity of the lithology and differences in extent of weathering. Apparent hydraulic conductivities of the bedrock at depths of 100 to 200 feet in burial ground 5's 5-south area ranged from 1.5 $x 10^{-4}$ to $1.9 \times 10^{-1} \mathrm{ft} / \mathrm{d}$. The trend is for values to decrease with depth, but the relation is imperfect, again reflecting the variability of the strata. By use of a flow-velocity that is based on a mean hydraulic conductivity value, it is estimated that the time required for ground water in burial grounds 5 and 6 to flow entirely in regolith and parallel to the longest flow line from a point of waste disposal to a receiving stream is about 5 to 6 years. Actual time of travel probably would be somewhat less because of other factors involved. In contrast, the time required for water to travel from the regolith, to the lower limit of bedrock saturation, to a discharge point in a drainage, would be measured at least in many decades if not in centuries.

Evidence exists that solution cavities of small cross-sectional area have developed in some of the limestone beds, but no evidence was obtained to demonstrate that an integrated cavity system has developed, such as appears to have occurred near ILW pits 2 and 4 . If such a cavity system is present below burial grounds 5 or 6 , it could provide the pathway for a disproportionate amount of flow at a more rapid rate than water flows in the surrounding rock. It also would 
afford minimal sorption and ion-exchange potential because of the comparatively small surface area involved in channelized flow.

Principal contaminants in the ground water of burial ground 5 are iron, tritium, and strontium-90. Although a wide variety of radionuclides are associated with the buried waste, the rate of transport of many of them through the Conasauga Group is significantly slowed by sorbtion and ion exchange.

Historically, monitoring has focused on the discharge at Whiteoak Dam in order to meet a legal requirement pertaining to the concentration of radionuclides released by ORNL to off- site areas. In view of the changed regulatory environment of recent years, and the demonstrated inability of the geologic media underlying Melton Valley to retain all of the radionuclides consigned to it, it seems imperative that a system designed more specifically for monitoring transport of hazardous substances from the waste-disposal areas be developed. The data and interpretations given herein provide a scientific basis for the initial design of such a surveillance system, material for constructing numerical models that simulate the ground-water flow system, and help in assessing the effectiveness of proposed remedial measures that are based on altering one or more aspects of groundwater flow.

\section{SELECTED REFERENCES}

Air Resources Atmospheric Turbulence and Diffusion Laboratory, 1972, Daily, monthly, and annual climatological data for Oak Ridge, Tennessee townsite and area stations January 1951 through December 1971: Oak Ridge, Tennessee, National Oceanic and Atmospheric Administration, Oak Ridge, Tennessee, $557 \mathrm{p}$.

Ames, L.L., and Rai, Dhanpat, 1978, Radionuclide interactions with soil and rock media, v. 1: U.S. Environmental Protection Agency, EPA 520/6-78-007, 307 p.

Arora, H.S., Huff, D.D., Ward, D.S., and Sealand, O.M., 1981, An assessment of the effect of a bentonite seal on groundwater storage in underlying waste disposal trenches at Oak Ridge National Laboratory: [U.S.] Department of Energy, Oak
Ridge National Laboratory (Report) ORNL/TM-7416, 44 p.

Barnett, John, 1954, Geological investigations, waste disposal area, Oak Ridge National Laboratory, Oak Ridge, Tennessee: Mariemont, Ohio, U.S. Army Corps of Engineers, Ohio River Division Laboratories, Mariemont, Ohio, 6 p., 2 maps.

Carroll, Dorothy, 1961, Soils and rocks of the Oak Ridge area, Tennessee: U.S. Geological Survey Trace Elements Investigations Report 785, $33 \mathrm{p}$.

Cerling, T.E., and Spalding, B.P., 1981, Area distribution of ${ }^{60} \mathrm{Co},{ }^{137} \mathrm{Cs}$, and ${ }^{90} \mathrm{Sr}$ in streambed gravels of White Oak Creek watershed, Oak Ridge, Tennessee: U.S. Department of Energy, Oak Ridge National Laboratory (Report) ORNL/TM-7318, $67 \mathrm{p}$. 
-.--1982, Distribution and relationship of radionuclides to streambed gravels in a small watershed: Journal of Environmental Geology, v. 4, no. 2, p. 99-115.

Cooper, H.H., Jr., Bredehoeft, J.D., and Papadopulos, I.S., 1967, Response of a finitediameter well to an instantaneous charge of water: Water Resources Research, v. 3, no. 1., p. 263-269.

Cowser, K.E., Lomenick, T.F., and McMaster, W.M., 1961, Status report on evaluation of solid waste disposal at ORNL: 1: U.S. A.tomic Energy Commission, Oak Ridge National Laboratory (Report) ORNL3035, $38 \mathrm{p}$.

Cowser, K.E., and Parker, F.L., 1958, Soil disposal of radioactive wastes at ORNL: criteria and techniques of site selection and monitoring: Health Physics, v. 1, p. 152163.

Davis, E.C., Boegly, W.J., Jr., Rothschild, E.R., Spalding, B.P., Vaughn, N.D., Haase, C.S., Huff, D.D., Lee, S.Y., Walls, E.C., Newbold, J.D., and Smith, E.D., 1984, Site characterization techniques used at a low-level waste shallow land burial field demonstration facility: U.S. Department of Energy, Oak Ridge National Laboratory (Report) ORNL/TM-9146, $173 \mathrm{p}$.

Davis, E.C., and Stansfield, R.G., 1984, Design and construction of a French drain for groundwater diversion in solid waste storage area six at the Oak Ridge National Laboratory: U.S. Department of Energy, Oak Ridge National Laboratory (Report) ORNL/TM-9014, $59 \mathrm{p}$.

DeBuchananne, G.D., and Richardson, R.M., 1956, Ground-water resources of east Ten- nessee: Tennessee Division of Geology Bulletin 58, Part I, 393 p.

deLaguna, Wallace, 1956, Some geologic factors that influence disposal of radioactive wastes into pits, in Seminar on sanitary engineering aspects of the Atomic Energy Industry, Cincinnati, 1955: U.S. Atomic Energy Commission, Division of Technical Information (Report) TID-7517, pt. 1b, p. 426-456.

deLaguna, Wallace, Cowser, K.E., and Parker, F.L., 1958, Disposal of high level radioactive liquid wastes in terrestial pits; a sequel, in Peaceful Uses of Atomic Energy International Conference $2 d$, United Nations, Geneva, 1958, Proceedings: United Nations, v. 18, p. 101-115.

Duguid, J.O., 1975, Status report on radioactivity movement from burial grounds in Melton and Bethel Valleys: U.S. Energy Research and Development Administration, Oak Ridge National Laboratory (Report) ORNL-5017, 66 p.

-----1976, Annual progress report of burial ground studies at Oak Ridge National Laboratory: period ending September 30, 1975: [U.S.] Energy and Research Development Administration, Oak Ridge National Laboratory (Report) ORNL-5141, $56 \mathrm{p}$.

Duguid, J.O., and Reeves, M., 1976, Material transport through porous media: a finiteelement Galerkin model: U.S. Energy Research and Development Administration, Oak Ridge National Laboratory (Report) ORNL-4928, $201 \mathrm{p}$.

Edgar, D.E., 1978, An analysis of infrequent hydrologic events with regard to existing streamflow monitoring capabilities in 
Whiteoak Creek watershed: U.S. Department of Energy, Oak Ridge National Laboratory (Report) ORNLTM-6542, 42 p.

Evaluation Research Corporation, 1982, History of disposal of radioactive wastes into the ground at Oak Ridge National Laboratory: [U.S.] Department of Energy, Oak Ridge National Laboratory (Report) ORNL/CF$82 / 202,123$ p.

Fenneman, N.W., 1938, Physiography of eastern United States: New York, McGraw-Hill, $714 \mathrm{p}$.

Haase, C.S., Stow, S.H., and Switek, J., 1984, The hydrofracture facility, in Oak Ridge National Laboratory, 1985, Environmental Sciences Division Annual Progress Report for period ending September 30, 1984: U.S. Department of Energy, Oak Ridge National Laboratory (Report) ORNL6140, p. 33-34.

Haase, C.S., and Vaughn, N.D., 1981, Stratigraphy and lithology of the Conasauga Group in the vicinity of Oak Ridge, Tennessee: Geological Society of America abstracts with programs, Boulder, Colo., v. 13 , no. 1, p. 8.

Haase, C.S., Walls, E.C., and Farmer, C.D., 1985, Stratigraphic and structural data for the Conasauga Group and the Rome Formation on the Copper Creek fault block near Oak Ridge, Tennessee: Preliminary results from test borehole ORNL-Joy No. 2: U.S. Department of Energy, Oak Ridge National Laboratory (Report) ORNL/TM9159, $88 \mathrm{p}$.

Hasson, K.O., and Haase, C.S., 1982, Stratigraphy of the Conasauga Group in the Valley and Ridge Province, east Tennessee:
Geological Society of America abstracts with programs, v. 14, p. 24.

-.-1984, Lithofacies and paleogeography of the Conasauga Group (Middle and Late Cambrian) in the Valley and Ridge Province of east Tennessee: American Association of Petroleum Geologists Bulletin.

Huff, D.D., and Farrow, N.D., 1983, Solid Waste Storage Area-4 Studies, in Oak Ridge National Laboratory, 1984, Environmental Sciences Division Annual Progress Report for period ending September 30, 1983: [U.S.] Department of Energy, Oak Ridge National Laboratory (Report) ORNL6009, p. 84-85.

Huff, D.D., Farrow, N.D., and Jones, J.R., 1982, Hydrologic factors and $90 \mathrm{Sr}$ transport: $\mathrm{A}$ case study: Environmental Geology, v. 4, no. 1, p. 53-63.

Hvorslev, M.J., 1951, Time lag and soil permeability in ground-water observations: Vicksburg, Miss., U.S. Army Corps of Engineers, Waterways Experiment Station Bulletin 36, $50 \mathrm{p}$.

Jenne, E.A., and Wahlberg, J.S., 1968, Role of certain stream-sediment components in radioion sorption: U.S. Geological Survey Professional Paper 433-F, 16 p.

Lomenick, T.F., and Cowser, K.E., 1961, Status report on evaluation of solid waste disposal at ORNL: II: U.S. Atomic Energy Commission, Oak Ridge National Laboratory (Report) ORNL-3182, 38 p.

Lomenick, T.F., Jacobs, D.G., and Struxness, E.G., 1967, The behavior of strontium-90 and cesium-137 in seepage pits at ORNL: Health Physics, v. 13, p. 897-905.

Lomenick, T.F., and Wyrick, H.J., 1965, Geohydrological evaluation of solid waste 
storage area 6: U.S. Atomic Energy Commission, Oak Ridge National Laboratory (Report) ORNL-TM-1327, 17 p.

McMaster, W.M., 1962, Geologic map of the Oak Ridge area Tennessee: U.S. A.tomic Energy Commission, 1 sheet, scale 1:31,680.

----1963, Geologic map of the Oak Ridge Reservation, Tennessee: U.S. Atomic Energy Commission, Oak Ridge National Laboratory (Report) ORNL-TM 713, 23 p.

----1967, Hydrologic data for the Oak Ridge area, Tennessee: U.S. Geological Survey Water-Supply Paper 1839-N, 60 p.

McMaster, W.M., and Waller, H.D., 1965, Geology and soils of White Oak Creek Basin, Tennessee: U.S. Atomic Energy Commission, Oak Ridge National Laboratory (Report) ORNL-1108, $37 \mathrm{p}$.

Melroy, L.A., and Huff, D.D., 1985, Annual reduction of ${ }^{90}$ Sr migration from Solid Waste Storage Area 4 to White Oak Creek by flow diversion: U.S. Department of Energy, Oak Ridge National Laboratory (Report) ORNL/TM-9620, $45 \mathrm{p}$.

Oak Ridge National Laboratory, Applied Health Physics Annual Report, annually, for 1957 through 1964: U.S. Atomic Energy Commission, Oak Ridge National Laboratory (Reports) CF-57-12-146 (1957), ORNL2777 (1958), -3073 (1959), -3159 (1960), 3284 (1961), -3490 (1962), -3665 (1963), -3820 (1964).

Applied Health Physics and Safety Annual Report, annually, for 1968 through 1976: U.S. Atomic Energy Commission, Oak Ridge National Laboratory (Reports) ORNL-4423 (1968); -4563 (1969); -4690 (1970); -4795 (1971); -4894 (1972); -4974
(1973); -5055 (1974); -5169 (1975); -5310 (1976).

1984, Environmental and Occupational Safety Division Annual Progress Report for 1983: U.S. Department of Energy, Oak Ridge National Laboratory (Report) ORNL-6077.

-----Health Physics and Safety Annual Report, annually, for 1965 through 1967: U.S. Atomic Energy Commission, Oak Ridge National Laboratory (Reports) ORNL3969 (1965); -4146 (1966); -4286 (1967).

-----Industrial Safety and Applied Health Physics Annual Report, annually, for 1977 through 1982: U.S. Department of Energy, Oak Ridge National Laboratory (Reports) ORNL-5420 (1977); -5543 (1978); -5563 (1979), -5821 (1980); -5859 (1981); -5962 (1982).

Olsen, C.R., Lowery, P.D., Lee, S.Y., Larsen, I.L., and Cutshall, N.H., 1983, Chemical, geological, and hydrological factors gov-erning radionuclide migration from a formerly used seepage trench: a field study: U.S. Department of Energy, Oak Ridge National Laboratory (Report) ORNL/TM8839, 106 p.

Papadopulos, I.S., Bredehoeft, J.D., and Cooper, H.H., Jr., 1973, On the analysis of "slug test" data: Water Resources Research, v. 9, no. 4, p. $1087-1089$.

Papadopulos, I.S., and Cooper, H.H., Jr., 1967, Drawdown in a well of large diameter: Water Resources Research, v. 3, no. 1, p. 241-244.

Pickering, R.J., 1970, Composition of water in Clinch River, Tennessee River, and Whiteoak Creek as related to disposal of lowlevel radioactive liquid wastes: U.S. 
Geological Survey Professional Paper 433$\mathrm{J}, 15 \mathrm{p}$.

Piper, A.M., 1944, A graphic procedure in the geochemical interpretation of water analyses: American Geophysical Union Transactions, v. 25, p. 914-923.

Reeves, M., and Duguid, J.O., 1975, Water movement through saturated-unsaturated porous media: a finite-element Galerkin model: U.S. Atomic Energy Commission, Oak Ridge National Laboratory (Report) ORNL-4927, $236 \mathrm{p}$.

Richardson, R.M., 1963, Significance of climate in relation to the disposal of radioactive waste at shallow depth below ground, in $\mathrm{La}$ rétention et la migration des ions radioactifs dans les sols - Colloque international, Saclay, France, 1962: Paris, Presses Universitaires de France, p. 207-211.

Rodgers, John, compiler, 1953, Geologic map of east Tennessee with explanatory text: Tennessee Division of Geology Bulletin 58, Part II, $168 \mathrm{p}$.

Rothschild, E.R., Huff, D.D., Haase, C.S., Clapp, R.B., Spalding, B.P., Farmer, C.D., and Farrow, N.D., 1984a, Geohydrologic characterization of proposed solid waste storage area 7: U.S. Department of Energy, Oak Ridge National Laboratory (Report) ORNL/TM-9314, 262 p.

Rothschild, E.R., Huff, D.D., Spalding, B.P., Lee, S.Y., Clapp, R.B., Lietzke, D.A., Stansfield, R.G., Farrow, N.D., Farmer, C.D., and Munro, I.L., 1984b, Characterization of soils at proposed solid waste storage area (SWSA) 7: U.S. Department of Energy, Oak Ridge National Laboratory (Report) ORNL/TM-9326, 147 p.
Sledz, J.J., and Huff, D.D., 1981, Computer model for determining fracture porosity in the Conasauga Group, Oak Ridge National Laboratory, Tennessee: [U.S.] Department of Energy, Oak Ridge National Laboratory (Report) ORNL/TM-7695, $138 \mathrm{p}$.

Steuber, A.M., Edgar, D.E., McFadden, A.F., and Scott, T.G., 1978, Preliminary investigation of ${ }^{90} \mathrm{Sr}$ in White Oak Creek between monitoring stations 2 and 3, Oak Ridge National Laboratory: [U.S.] Department of Energy, Oak Ridge National Laboratory (Report) ORNLTM-6510, $80 \mathrm{p}$.

Steuber, A.M., Huff, D.D., Farrow, N.D., Jones, J.R., and Munro, I.L., 1981, An evaluation of some ${ }^{90} \mathrm{Sr}$ sources in the White Oak Creek drainage basin: [U.S.] Department of Energy, Oak Ridge National Laboratory (Report) ORNL/TM-7290, 38 p.

Struxness, E.G., Morton, R.J., and Straub, C.P., 1956, Disposal of high level radioactive liquid wastes in terrestrial pits, in International conference on the peaceful uses of atomic energy, United Nations, Geneva, 1955, Proceedings: New York, United Nations, P/554, v. 9, p. 684-691.

Swann, M.E., Roberts, Wallace, Hubbard, E.N., and Porter, H.C., 1942, Soil Survey of Roane County, Tennessee: U.S. Department of Agriculture Bureau of Plant Industry series 1936, no. 15, $125 \mathrm{p}$.

U.S. Environmental Protection Agency, 1977, Procedures manual for ground water monitoring at solid waste disposal facilities: Cincinnati, Ohio, U.S. Environmental Protection Agency, EPA/530/SW-611, $269 \mathrm{p}$. 
U.S. Greological Survey, 1964, Cornpilation of records of surface waters of the United States, October 1950 to September 1960, Part 3-B. Cumberland and Tennessee River Basins: U.S. Geological Survey Water-Supply Paper 1726, 269 p.

----1971, Surface-water supply of the United States 1961-65, Part 3, v. 4. Ohio River Basin: U.S. Geological Survey Water-Supply Paper 1910, 738 p.

Vaughn, N.D., Haase, C.S., Huff, D.D., Lee, S.Y., and Walls, E.C., 1982, Field demonstration of improved shallow land burial practices for low-level radioactive solid wastes: preliminary site characterization and progress report: [U.S.] Department of Energy, Oak Ridge National Laboratory (Report) ORNL/TM-8477, 112 p.

Webster, D.A., 1976, A review of hydrologic and geologic conditions related to the radioactive solid-waste burial grounds at Oak Ridge National Laboratory, Tennessee: U.S. Geological Survey Open-File Report 76-727, $85 \mathrm{p}$.

----1979, Land burial of solid radioactive waste at Oak Ridge National Laboratory, Tennessee: a case history, in Carter, M.W., Moghissi, A.A., and Kahn, Bernd, eds., Management of Low-Level Radioactive Waste Symposium, Atlanta, Georgia, 1977, Proceedings: New York, Pergamon Press, v. 2, p. 731-746.

Webster, D.A., Beatty, J.S., Benjamin, P.M., and Tranum, W.M., 1980, Water-level data for wells in burial ground 6, Oak Ridge National Laboratory, Tennessee, 1975-1979: U.S. Geological Survey Open-File Report 81-57, $100 \mathrm{p}$. ----1981a, Water-level data for wells in and near burial ground 4, Oak Ridge National Laboratory, Tennessee, 1975-1979: U.S. Geological Survey Open-File Report 81-339, $52 \mathrm{p}$.

1981b, Water-level data for wells in and near burial ground 3, Oak Ridge National Laboratory, Tennessee, 1975-1979: U.S. Geological Survey Open-File Report 81-489, $35 \mathrm{p}$.

1982a, Water-level data for wells in burial ground 5, Oak Ridge National Laboratory, Tennessee, 1975-1979: U.S. Geological Survey Open-File Report 82-372, 135 p. $-1982 b$, Precipitation data for burial grounds 5 and 6, Oak Ridge National Laboratory, Tennessee, 1976-1980: U.S. Geological Survey Open-File Report 82-254, 15 p.

Yeh, G.T., and Huff, D.D., 1983, FEWA: A finite-element model of water flow through aquifers: [U.S.] Department of Energy, Oak Ridge National Laboratory (Report) ORNL-5976, 216 p.

Yeh, G.T., and Strand, R.H., 1982a, FECWATER: User's manual of a finite- element code for simulating WATER flow through saturated-unsaturated porous media: [U.S.] Department of Energy, Oak Ridge National Laboratory (Report) ORNL/TM-7316, 237 p.

1982b, FECWASTE: User's manual of a finite-element code for simulating WASTE transport through saturated-unsaturated porous media: [U.S.] Department of Energy, Oak Ridge National Laboratory (Report) ORNL/TM-8104, $302 \mathrm{p}$.

Yeh, G.T., and Ward, D.S., 1980, FEMWATER: A finite-element model of WATER flow 
through saturated-unsaturated porous media: [U.S.] Department of Energy, Oak Ridge National Laboratory (Report) ORNL-5567, $153 \mathrm{p}$.

-..-1981, FEMWASTE: A finite-element model of WASTE transport through satu- rated-unsaturated porous media: [U.S.] Department of Energy, Oak Ridge National Laboratory (Report) ORNL-5601, $137 \mathrm{p}$. 
APPENDIX

Date of selected wells described in text and llluetrations

[Casing type: P. Plastic; S - Steel; Finish: Opn - Open bore, Prf - Perforated casing. Sit - Slotted screen]

\begin{tabular}{|c|c|c|c|c|c|c|c|}
\hline \multirow[b]{2}{*}{$\begin{array}{l}\text { Woll } \\
\text { No. }\end{array}$} & \multirow[b]{2}{*}{$\begin{array}{l}\text { ORNL Grid } \\
\text { (feet) }\end{array}$} & \multirow[b]{2}{*}{$\begin{array}{l}\text { Depth } \\
\text { of } \\
\text { well } \\
\text { (feet) }\end{array}$} & \multicolumn{3}{|c|}{ Casing } & \multicolumn{2}{|c|}{ Finish } \\
\hline & & & $\begin{array}{c}\text { Diam- } \\
\text { eter } \\
\text { (inches) }\end{array}$ & $\begin{array}{l}\text { Ter- } \\
\text { minal } \\
\text { depth } \\
\text { (feet) }\end{array}$ & Typo & $\begin{array}{l}\text { Char- } \\
\text { acter }\end{array}$ & $\begin{array}{l}\text { Depth of } \\
\text { open } \\
\text { interval }\end{array}$ \\
\hline
\end{tabular}

\begin{tabular}{cc}
$\begin{array}{c}\text { Well } \\
\text { No. }\end{array}$ & $\begin{array}{c}\text { ORNL Grid } \\
\text { (feet) }\end{array}$ \\
\hline
\end{tabular}

\begin{tabular}{|c|c|c|c|c|c|}
\hline & & Casing & & & ish \\
\hline $\begin{array}{l}\text { epth } \\
\text { of } \\
\text { weil } \\
\text { feet) }\end{array}$ & $\begin{array}{c}\text { Diam- } \\
\text { eter } \\
\text { (inches) }\end{array}$ & $\begin{array}{l}\text { Ter- } \\
\text { minal } \\
\text { depth } \\
\text { (feet) }\end{array}$ & Type & $\begin{array}{l}\text { Char- } \\
\text { acter }\end{array}$ & $\begin{array}{l}\text { Depth of } \\
\text { open } \\
\text { interval }\end{array}$ \\
\hline
\end{tabular}

Burial Ground 4

$\begin{array}{lll}\text { 186A } & \text { N19058 } & \text { E27514 } \\ 188 & N 19602 & \text { E28052 } \\ 189 & N 19404 & \text { E28048 } \\ 192 & N 19396 & E 28573 \\ 196 & \text { N19059 } & E 28856\end{array}$

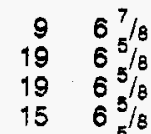

9
19
6
15
11

$\begin{array}{ll}\text { Prf } & 0-9 \\ \text { Prf } & 0-19 \\ \text { Prf } & 0-19 \\ \text { Prf } & 0-15 \\ \text { Prf } & 0-11\end{array}$

201 Nis

203 N19001 E28572

4-4 N19548 E27777

4-11 N19548 E27765

$$
\begin{array}{ll}
29 & 3 \\
19 & 65 / 8 \\
30 & 6 \\
27 & 6
\end{array}
$$

$27 \quad 6$

$2 \overline{9}$

4-11 N19548 E27765

$30 \quad 3$

531 N19216 E28314

$\begin{array}{lll}\mathbf{5 3 3} & \text { N19216 } & \mathrm{E} 28314 \\ \mathbf{5 3 4} & \mathrm{N} 19115 & \mathrm{E} 27926\end{array}$

536 N19108 E27210

$$
\begin{array}{ll}
30 & 3 \\
30 & 3 \\
30 & 3
\end{array}
$$

$\begin{array}{llll}19 & \mathrm{~S} & \text { Sit } & 0.29 \\ 5 & \mathrm{P} & \text { Prf } & 0.19\end{array}$

$\begin{array}{ll}\text { Prf } & 0-19 \\ \text { Opn } & 5-30\end{array}$

Opn $5-30$

Opn 5-21

$\begin{array}{llll}5 & P & \text { Opn } & \mathbf{5 - 3 0} \\ 5 & \mathrm{P} & \text { Opn } & \mathbf{5 - 3 0} \\ 5 & \mathrm{P} & \text { Opn } & 5-30 \\ 5 & \mathrm{P} & \text { Opn } & 5-30\end{array}$

$174 \quad$ N17629 E 30382

$\begin{array}{lll}175 & N 17521 & E 30214 \\ 176 & N 17820 & E 29329\end{array}$

$\begin{array}{lll}176 & N 17829 & E 29329 \\ 177 & N 17529 & E 29358\end{array}$

178 N17572 E28864

Burial Ground 5

$419 \quad N 17008$ E29218 432 N17958 E29101 $433 \quad N 17488$ E29071 $434 \mathrm{~N} 17393 \mathrm{E} 29119$ 435 N17232 E28990

$1258 \%$

$148 \quad 6 \frac{1}{143} 6{ }^{1 / 8}$

$143 \quad 6 \%$

$1536 \frac{1}{8}$

$\begin{array}{llll}14 & \text { S } & \text { Opn } & 14-125 \\ 36 & \mathrm{~S} & \text { Opn } & 36-148 \\ 36 & \mathrm{~S} & \text { Opn } & 36-143\end{array}$

Opn 44-149

$17 \quad 6^{5} / 8$

$\begin{array}{ll}27 & 3 \\ 44 & 3\end{array}$

$\begin{array}{ll}32 & 3 \\ 30 & 3\end{array}$

$436 \quad N 17081$ E29080

437 N17270 E29209

$438 \quad N 17418$ E29317

$439 \quad \mathrm{~N} 17134$ E29297

$440 \quad N 17280$ E29382

$433 \quad \mathrm{~N} 17185$ E28723

444 N17149 E30017

445 N17652 E30286

$\begin{array}{ll}31 & 3 \\ 36 & 3 \\ 37 & 3 \\ 34 & 3 \\ 36 & 3 \\ & \\ 47 & 3 \\ 21 & 3 \\ 64 & 3\end{array}$

17
27
44
32
30

$\begin{array}{lr}\text { Pif } & 0.17 \\ \text { Sit } & 17-27 \\ \text { Slt } & 34-44 \\ \text { Slt } & 22-32\end{array}$

$22-32$
$20-30$

21-31

26-36

$27-37$

$24-34$

37.47

$\begin{array}{llllll}47 & 3 & 47 & P & \text { Sit } & 37.47 \\ 21 & 3 & 21 & P & \text { Sit } & 11.21 \\ 64 & 3 & 64 & P & \text { Sit } & 54.64\end{array}$

$446 \quad$ N17184 E29520

$447 N 17778$ E28992

$\begin{array}{lll}448 & N 18056 & E 29325 \\ 450 & N 17850 & E 30073\end{array}$

$\begin{array}{lll}450 & N 17850 & E 30073 \\ 451 & N 17581 & E 29962\end{array}$

$\begin{array}{rr}29 & 3 \\ 8 & 3 \\ 60 & 3 \\ 34 & 3 \\ 34 & 3\end{array}$

$\begin{array}{llll}452 & N 17341 & \text { E29827 }\end{array}$

453 N1722̄3 E30290

$455 N 18007$ E30198

$458 \quad N 17254 \quad E 29367$

458A N17254 E29367

$459 \quad N 17228$ E29355

459A N17228 E29355

$460 \quad N 17185$ E29347

$462 N 16888$ E20562

463 N16901 E29541

$464 N 16918$ E29523

465 N17525 E28585

466 N17503 E29573

$467 N 17480$ E28563

$468 \quad N 17457$ E28551

469A N18011 E29984

470 N18016 E29956

$\begin{array}{lll}471 & N 18034 & E 29867 \\ 472 & N 18026 & E 29914\end{array}$

$473 \quad N 17225$ E30466

474 N17239 E30489

475 N17247 E30501

$476 \quad N 17265$ E30532

513 N18440 E29209

$514 \quad N 18452 \quad$ E29537

$517 \quad N 18937$ E29575

520 N18681 E30024

522 N19040 E29805

525 N18871 E30279

$526 \quad$ N18416 E29878

$527 N 18355$ E30221

T60-1 N17075 E29094
T64-1 N?7061 E29511

303

$\begin{array}{ll}29 & 3 \\ 36 & 3\end{array}$

2025

$\begin{array}{lr}202 & 5 \\ 150 & 12\end{array}$

$\begin{array}{ll}140 & 5 \\ 150 & 8\end{array}$

$\begin{array}{ll}150 & 8 \\ 100 & 5\end{array}$

2024

2024

1004

$\begin{array}{rr}11 & 4 \\ 201 & 4\end{array}$

1524

154

$\begin{array}{rr}15 & 4 \\ 201 & 4\end{array}$

$\begin{array}{rr}151 & 4 \\ 99 & 4\end{array}$

$\begin{array}{ll}99 & 4 \\ 20 & 4\end{array}$

$\begin{array}{ll}200 & 4 \\ 151 & 4\end{array}$

$\begin{array}{ll}151 & 4 \\ 100 & 4\end{array}$

$\begin{array}{ll}30 & 4 \\ 20 & 6\end{array}$

306

326

246

26

$\begin{array}{ll}26 & 4 \\ 16 & 4\end{array}$

$\begin{array}{ll}14 & 3 \\ 15 & 3\end{array}$ 
APPENDIX

Data of selected wells described in text and illustrations--Continued

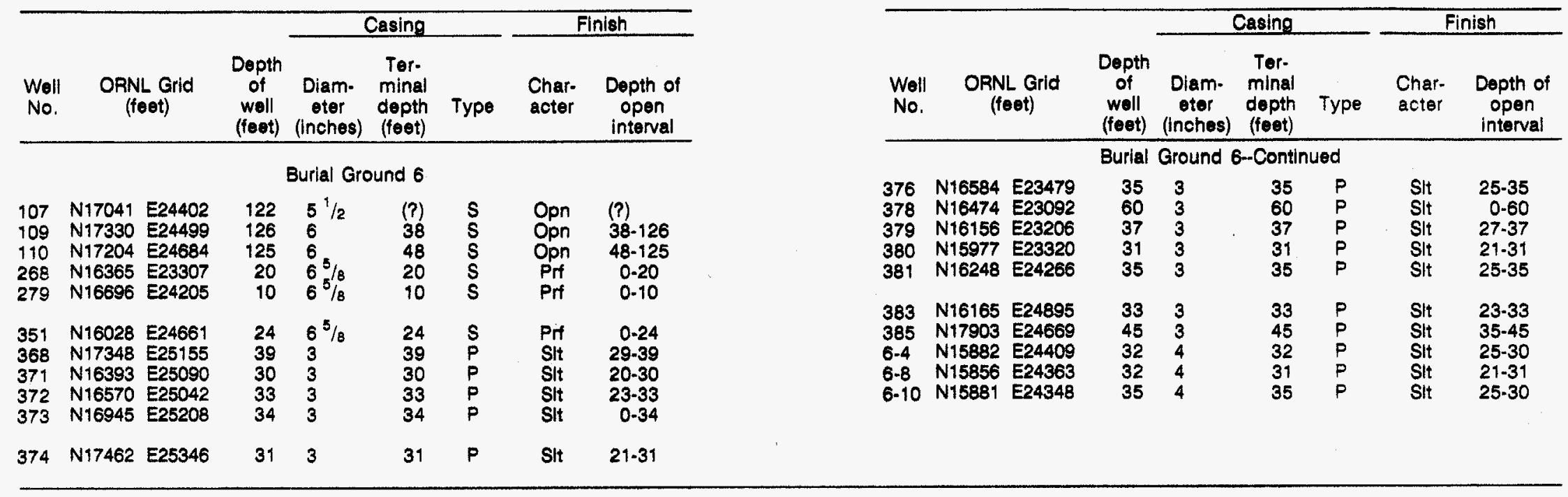

